University of Pittsburgh School of Law

Scholarship@PITT LAW

1993

\title{
Of Diagnoses and Discrimination: Discriminatory Nontreatment of Infants with HIV Infection
}

Mary Crossley

University of Pittsburgh School of Law, crossley@pitt.edu

Follow this and additional works at: https://scholarship.law.pitt.edu/fac_articles

Part of the Civil Rights and Discrimination Commons, Disability Law Commons, Disability Studies

Commons, Family Law Commons, Health Law and Policy Commons, Inequality and Stratification

Commons, Insurance Law Commons, Law and Society Commons, Other Anthropology Commons,

Political Economy Commons, Public Economics Commons, and the Social Welfare Law Commons

\section{Recommended Citation}

Mary Crossley, Of Diagnoses and Discrimination: Discriminatory Nontreatment of Infants with HIV Infection, 93 Columbia Law Review 1581 (1993).

Available at: https://scholarship.law.pitt.edu/fac_articles/414

This Article is brought to you for free and open access by the Faculty Publications at Scholarship@PITT LAW. It has been accepted for inclusion in Articles by an authorized administrator of Scholarship@PITT LAW. For more information, please contact leers@pitt.edu, shephard@pitt.edu. 


\title{
COLUMBIA LAW REVIEW
}

VOL. 93

NOVEMBER 1993

NO. 7

\section{OF DIAGNOSES AND DISCRIMINATION: DISCRIMINATORY NONTREATMENT OF INFANTS WITH HIV INFECTION}

\author{
Mary $A$. Crossley*
}

\section{INTRODUCTION}

In April 1982, in Bloomington, Indiana a newborn with Down syndrome died of starvation six days after his parents refused to consent to surgery to correct an obstruction of his digestive tract. ${ }^{1}$ The dying of "Baby Doe," as the infant became known, sparked a public outcry, spurred regulatory and legislative responses by the federal government, and spawned literally volumes of commentary. ${ }^{2}$ Today, over ten years later, the issue for which the Baby Doe case has become a symbol-selective nontreatment of disabled newborns ${ }^{3}$ - continues to pro-

* Assistant Professor, University of California, Hastings College of the Law. B.A. 1984, University of Virginia; J.D. 1987, Vanderbilt University.

1. See infra notes 87-91 and accompanying text.

2. See, e.g., Robert F. Weir, Selective Nontreatment of Handicapped Newborns: Moral Dilemmas in Neonatal Medicine (1984); Which Babies Shall Live? Humanistic Dimensions of the Care of Imperiled Newborns (Thomas H. Murray \& Arthur L. Caplan eds., 1985); Patricia A. Barber et al., Parental Perspectives on Treatment-Nontreatment Decisions Involving Newborns with Spina Bifida, in Compelled Compassion: Government Intervention in the Treatment of Critically Ill Newborns 123, 128-29 (Arthur L. Caplan et al. eds., 1992) [hereinafter Compelled Compassion]; Phoebe A. Haddon, Baby Doe Cases: Compromise and Moral Dilemma, 34 Emory L.J. 545 (1985); Hastings Center Newborns Project on the Care of Imperiled Newborns, Hastings Center Rep., Dec. 1987, at 5 [hereinafter Newborns Project]; C. Everett Koop, Life and Death and the Handicapped Newborn, 5 Issues L. \& Med. 101 (1989); Legislative Workshop, Baby Doe: Problems and Legislative Proposals, 1984 Ariz. St. L.J. 601; Stephen A. Newman, Baby Doe, Congress and the States: Challenging the Federal Treatment Standard for Impaired Infants, 15 Am. J.L. \& Med. 1 (1989); Nancy K. Rhoden, Treatment Dilemmas for Imperiled Newborns: Why Quality of Life Counts, 58 S. Cal. L. Rev. 1283 (1985); Carl E. Schneider, Rights Discourse and Neonatal Euthanasia, 76 Cal. L. Rev. 151 (1988); George P. Smith, 1l, Murder, She Wrote or Was It Merely Selective Nontreatment?, 8 J. Contemp. Health L. \& Pol'y 49 (1992); Special Section on the Treatment of Handicapped Newborns, 11 J. Health Pol. Pol'y \& L. 195 (1986).

3. Baby Doe was not the only, or even the first, infant whose selective nontreatment caught the public's attention. See Newborns Project, supra note 2, at 8; see also infra notes 86,100 . Moreover, treating Baby Doe's case as a paradigm in analyzing the legal and ethical issues raised by selective nontreatment fails to acknowledge the diversity of treatment issues that arise from the wide variety of congenital defects infants can suffer. Nonetheless, this Article will use the terms "Baby Doe" and the "Baby Doe controversy" as representative of the debate that commenced in the early 1980 s over selective nontreatment.

The literature on selective nontreatment uses the terms "imperiled," "severely 
voke debate. Today, however, the issue is also finding a new embodiment.

Less than a year after Baby Doe's death, a group of physicians in New Jersey made the first diagnosis of pediatric Acquired Immune Deficiency Syndrome (AIDS). ${ }^{4}$ In 1982, there probably seemed to be little connection between the death of Baby Doe and this first diagnosis. But in 1991, the Journal of the American Medical Association (JAMA) published the results of a survey of health professionals involved in the care of critically ill newborns at six hospitals in New York City (the JAMA survey)..$^{5}$ The results of this survey, which was designed to investigate beliefs about appropriate management for a series of hypothetical infants, some at risk for ${ }^{6}$ or infected with human immunodeficiency virus (HIV), ${ }^{7}$ made the connection between Baby Doe and the growing number of pediatric AIDS cases disquietingly clear: A significant number of those polled indicated that they would be less likely to recommend aggressive treatment of a life-threatening condition for a newborn infected with HIV than they would if the infant suffering the lifethreatening condition had no known HIV risk. ${ }^{8}$

defective," "anomalous," and "handicapped," among others, to describe infants born with congenital defects or extremely prematurely. Because this Article seeks to draw connections and distinctions between those infants whose treatment dilemmas have already been debated and infants with HIV infection, it will primarily use the term "disabled infant" as an inclusive term to describe all such infants.

4. See James Oleske et al., Immune Deficiency Syndrome in Children, 249 JAMA 2345, 2345 (1983) [hereinafter Oleske, Immune Deficiency]. The first cases of pediatric AIDS reported to the federal Centers for Disease Control (CDC) in December 1982 involved children who had received blood transfusions. Later that month, four children under the age of two years with AIDS-like symptoms and no history of blood transfusions were reported to the CDC. In early 1983 the CDC established a definition for pediatric AIDS. See id. at 2347-49.

Although pediatric AIDS was not diagnosed until 1982, it appears that sporadic cases of children with HIV infection occurred in the mid to late 1970s. The first known case of pediatric AIDS occurred in 1978 in a child who may have acquired the infection either perinatally or from a blood transfusion. At the time, the child's physicians were mystified by the child's illness, and the AIDS diagnosis was not made until years later when a serum specimen saved from 1978 tested positive for HIV. See James M. Oleske, AIDS in Our Children-Who Cares for Them?, 5 Issues L. \& Med. 437, 437 (1990) [hereinafter Oleske, AIDS in Our Children].

5. See Betty W. Levin et al., Treatment Choice for Infants in the Neonatal Intensive Care Unit at Risk for AIDS, 265 JAMA 2976, 2976-80 (1991).

6. An infant is deemed "at risk" for HIV if it is born to a mother who is infected with HIV. See id. at 2976.

7. HIV is the virus that causes AIDS. The term "HIV positive" describes someone who has tested positive for the virus and is used interchangeably with "HIV infected." See infra note 37 for a description of methods of testing for HIV.

8. The survey asked respondents, who included neonatologists, neonatal fellows, pediatric residents, and neonatal nurses, to indicate treatment recommendations regarding treatment for hypothetical cases involving an infant (1) whose mother is known to have AIDS; (2) who is known to be HIV infected; (3) who has Down syndrome; (4) who has cystic fibrosis; (5) who has Tay-Sachs disease; (6) who has Trisomy 13 syndrome; and (7) who has no genetic condition or specific AIDS risk. For a description 
In its design the JAMA survey consciously referred back to the Baby Doe case. ${ }^{9}$ It sought to determine how respondents' treatment recommendations for infants with life-threatening conditions unrelated to HIV, such as duodenal atresia ${ }^{10}$ or chronic kidney failure, would vary depending on whether the infant (1) suffered from one of a number of genetic conditions, (2) was at risk for HIV infection, (3) was known to be HIV infected, or (4) had no genetic condition or known HIV risk. That a higher percentage of the respondents would recommend aggressive treatment for infants with Down syndrome than would recommend such treatment for infants with HIV infection both reflects a shift in the decade since Baby Doe in physicians' attitudes towards aggressive treatment of Down syndrome infants and reveals a reluctance on the part of a significant number of respondents to treat HIV-infected

of Trisomy 13 syndrome and Tay-Sachs disease, see Rhoden, supra note 2 , at 1288 , 1292. In each case, the survey asked whether the respondent would recommend a specified treatment for a condition suffered by the infant. The hypothetical conditions (and corresponding treatments) posed by the survey included duodenal atresia (intravenous feedings or intestinal surgery), ventriculoseptal defect (open-heart surgery), chronic kidney failure (kidney dialysis), and chronic kidney failure combined with cardiac arrest (cardiac resuscitation). The survey instructed respondents to assume that the infant's parents' views were the same as their own. See Levin et al., supra note 5 , at 2977.

Of the 316 surveys distributed, $247(78 \%)$ were returned. The researchers summarized the results of the survey as follows:

Although there were some statistically significant differences, the proportions of respondents recommending each treatment for the infant whose mother had AIDS were similar to those for an infant with Down syndrome (a chromosomal abnormality causing mental retardation) or cystic fibrosis (a chronic, debilitating condition from which patients often die during adolescence or early adulthood). The recommendations for an infant known to be infected with HIV were similar to those for an infant with Tay-Sachs disease (a severe, deteriorating neurological condition that causes death within the first 2 years of life).

Id. at 2979.

For example, for an infant with a ventriculoseptal defect, the following percentages of respondents would recommend open-heart surgery:

$\begin{array}{lc}\text { no other condition or AIDS risk } & 97 \% \\ \text { cystic fibrosis } & 84 \% \\ \text { Down syndrome } & 84 \% \\ \text { at risk for HIV } & 77 \% \\ \text { known HIV infection } & 42 \% \\ \text { Tay-Sachs disease } & 31 \% \\ \text { Trisomy 13 syndrome } & 9 \%\end{array}$

Id. at 2978.

9. See Levin et al., supra note 5, at 2977 ("Seven vignettes were patterned after a well-known case of an infant with Down syndrome.").

10. Duodenal atresia is a form of intestinal obstruction that involves either the absence or obstruction of a portion of the duodenum. Surgery can successfully correct the obstruction, though not the absence, of a portion of the duodenum in a great majority of cases. Infants who do not receive the surgery die. See Weir, supra note 2, at 44. 
infants aggressively. For example, in the case of an infant with duodenal atresia, $99.6 \%$ of the respondents would recommend corrective intestinal surgery for a full-term infant with no other concurrent conditions; $97 \%$ would recommend such surgery for an infant with Down syndrome; and $75 \%$ would recommend surgery for an infant infected with HIV. ${ }^{11}$

Responses regarding treatment decisions for infants at risk for or infected with HIV were based on both social and medical considerations, although survey data indicated that many of the health professionals were not knowledgeable about current information concerning perinatal HIV infection. ${ }^{12}$ Reasons cited by respondents for recommending less aggressive treatment for HIV-infected infants included their concern for the poor quality of life and short life span that an HIV-infected infant could anticipate. Their quality-of-life concerns related not simply to the infant's expected suffering from AIDS, but also to the likelihood that the infant's mother would die of AIDS and that the infant would live in a "poor social environment."13 While acknowledging that selective nontreatment of infants with HIV-infected mothers may not yet present a significant practical problem, ${ }^{14}$ the au-

11. See Levin et al., supra note 5 , at 2978. Although the issue that the Baby Doe case has come to symbolize is commonly referred to as "selective nontreatment," while the JAMA survey's results describe hypothetical failures to provide aggressive treatment, the issues are usually one and the same. Only infrequently would cases of selective nontreatment involve a failure to provide any treatment or care whatsoever. The more common scenario involves a choice between aggressive and conservative treatment of a condition. See, e.g., United States v. University Hosp., 729 F.2d 144, 146 (2d Cir. 1984) (considering propriety of parental choice of conservative rather than aggressive surgical treatment of child with multiple birth defects).

12. See Levin et al., supra note 5 , at 2980 . Moreover, although some respondents may have decided to withhold treatment for HIV-infected infants solely on a medical basis, these decisions would not be consistent with the "medical effects approach" proposed in this Article because the questions posed by the survey did not include the particularized information regarding an individual infant's condition and prognosis that would allow respondents to engage in an individualized decision-making process. See infra text accompanying note 269 .

13. See Levin et al., supra note 5 , at 2980 . In open-ended questions, the survey asked respondents to explain decisions to withhold treatment both from infants known to be infected with HIV and from infants at risk of HIV infection. The published report contains no further indication as to what respondents meant by "poor social environment."

14. See id. at 2980. The authors themselves were unaware of any case in which the infant of an HIV-positive mother had been denied appropriate treatment in a neonatal intensive care unit (NICU). They attributed the small number of actual cases presenting ethical dilemmas about the aggressiveness of treatment for such infants to the fact that, to date, relatively few newborns admitted to a NICU had been identified as infants of HIV-positive mothers. The authors, however, reasoned that these ethical dilemmas are likely to arise more frequently in the future "if more mothers are identified as infected with HIV, if more newborns are screened and found to be positive for antibody, and/or if a test is developed and adopted in clinical practice that can identify infected newborns." $1 \mathrm{~d}$. 
thors were troubled by the survey's results, in terms of both the inaccuracy of medical information on which a number of responses were based and the willingness of respondents to withhold from infants at risk for AIDS life-sustaining treatment that would be provided for infants who may not similarly be at risk. ${ }^{15}$

Do the JAMA survey's findings simply present a case of "same song, second verse?" Does the JAMA survey merely demonstrate the failure of some health care professionals to generalize the controversy over Baby Doe and the resulting legal proscriptions regarding nontreatment to the emerging population of HIV-infected infants? Despite the obvious parallels the JAMA survey drew between medical decisionmaking for infants with genetic conditions and those infected with HIV, to what extent are the ethical and legal issues raised by the potential nontreatment of HIV-infected infants distinctive from those so exhaustively, if not conclusively, addressed in the 1980s?

As a general matter, it is unclear whether the federal government's response to Baby Doe was effective in ending the practice of selective nontreatment, for finding reliable evidence of the extent of selective nontreatment is as difficult today as it was in the early 1980 s. $^{16}$ As before, our best clue to the continuing prevalence of selective nontreatment may be the attitudes of the medical profession toward the practice, as revealed in recent ${ }^{17}$ medical literature.

That literature sends somewhat mixed messages. Although members of the medical profession have criticized the federal government's

15. See id. at 2981. The authors also expressed their own view regarding the appropriate response to the ethical dilemmas posed by the survey:

We believe thoughtful consideration of all relevant information, including upto-date information on the prognosis for children with perinatally acquired HIV infection as well [as] the prognosis for the other concurrent conditions, will be needed. Future suffering is relevant in assessing treatment choices. If an infant is likely to live only a short time and during that time to suffer from the illness and treatment, we believe aggressive treatment may not be in the child's best interest. However, if an infant will have a good chance to live and enjoy life for meaningful period of time, we believe neonatal treatment ought to be provided at least until the child's condition deteriorates. Judgments will need to be made about the value of particular treatments for individual infants.

Id. This approach to treatment decisions appears to be both consistent with the "best interests" approach described infra in Part IV.B and permissible under the proposed "medical effects" interpretation of the Americans with Disabilities Act articulated infra in Part VI.B.3.

16. See infra Part IIl.A. In the heyday of the Baby Doe debate, proponents of federal intervention claimed that deaths like Baby Doe's were commonplace, while opponents claimed that selective nontreatment occurred only rarely. Then, as today, no reliable figures were available regarding the extent of the practice. See generally $\mathrm{H}$. Rutherford Turnbull III, Incidence of Infanticide in America: Public and Professional Attitudes, 1 Issues L. \& Med. 363, 379-83 (1986) (detailing paucity and relative inconclusiveness of data).

17. I use the term "recent" broadly to include medical literature that postdates the Baby Doe controversy and the federal government's response by at least several years. 
attempts to regulate nontreatment, ${ }^{18}$ recent surveys suggest that at least some physicians have responded to regulation by changing their practices. A study of Massachusetts pediatricians published in 1988 found that $73 \%$ would recommend corrective intestinal surgery for a newborn with Down syndrome, ${ }^{19}$ and the JAMA survey found that $97 \%$ of its respondents would provide such surgery for a Down syndrome infant. ${ }^{20}$ This shift in medical attitudes towards infants with Down syndrome, however, may be as much the product of society's increasing

18. One national survey of neonatologists has been interpreted as showing that many respondents believed that the federal standards issued under the Child Abuse Amendments were a mistake and that their mandates could conflict with a neonatologist's duty to act in the best interests of a specific infant. See Loretta $M$. Kopelman et al., Neonatologists Judge the "Baby Doe" Regulations, 318 New Eng. J. Med. 677, 679, 683 (1988). Eighty-one percent of the neonatologists disagreed with the statement that the regulations would result in improved care for all infants, and more than $75 \%$ disagreed with the statement that the regulations were needed to protect the rights of handicapped infants. See id. at 679. But see Glyn Y. York et al., Baby Doe Regulations and Medical Judgment, 30 Soc. Sci. Med. 657, 659-64 (1990) (disputing Kopelman's interpretation of the data).

A related concern frequently voiced by physicians is that the federal standards act to increase infants' suffering by promoting overtreatment in some cases. See Jeanne $H$. Guillemin \& Lynda L. Holmstrom, Mixed Blessings: Intensive Care for Newborns 14, 281-82 (1986) (stating that overtreatment is the "more common jeopardy"); Kopelman et al., supra, at 679; Sarah Glazer, Born Too Soon, Too Small, Too Sick: Whatever Happened to Baby Doe?, Wash. Post, Apr. 2, 1991, Health Supp., at 8 (quoting physicians who question the wisdom of providing "heroic treatment at exorbitant cost"). Physicians have also criticized the federal Baby Doe rules as diverting attention and resources away from the more pressing, and easily addressed, problem of infant mortality associated with low birth weight. See John Lantos, Baby Doe Five Years Later: Implications for Child Health, 317 New Eng. J. Med. 444, 445 (1987).

19. See I. David Todres et al., Life-Saving Therapy for Newborns: A Questionnaire Survey in the State of Massachusetts, 81 Pediatrics 643, 643 (1988). Both the sample population and the question posed in the Massachusetts survey varied slightly from those in the JAMA survey. In the Massachusetts study, the questionnaire asked pediatricians: "Baby A has Down syndrome and was born with duodenal atresia. The parents have been consulted and do not want to consent to surgery to repair the intestinal obstruction. ... . Do you feel this baby should be operated on?" Id. at 647 . While similarly posing the scenario where an infant with Down syndrome is found to have duodenal atresia correctable by routine surgery, the JAMA survey asked health professionals involved in neonatal care whether they would provide corrective surgery, assuming the infant's parents' views were the same as their own. See Levin et al., supra note 5, at 2977. It should be noted that physicians in the Massachusetts survey who recommended surgery did so despite the parents' objection to surgery. It is reasonable to speculate that the percentage of respondents recommending surgery might have been higher had the question posed assumed, as the JAMA survey's question did, the parents' agreement with the physician's view.

20. See Levin et al., supra note 5, at 2978. A comparison of these figures to those obtained by similar studies in the mid-1970s demonstrates the shift in attitudes. See Anthony Shaw et al., Ethical Issues in Pediatric Surgery: A National Survey of Pediatricians and Pediatric Surgeons, 60 Pediatrics 588, 591-92 (1977) (finding that $19.9 \%$ of pediatric surgeons and $43.7 \%$ of pediatricians would recommend surgery for Down syndrome infant with duodenal atresia); I. David Todres et al., Pediatricians' Attitudes Affecting Decision-making in Defective Newborns, 60 Pediatrics 197, 197-98 
acceptance of persons with mental retardation as it is the response to changed legal requirements. ${ }^{21}$

Moreover, although these surveys reflect shifts in attitudes, the shifts may simply be at the margins; in other words, some physicians may still condone selective nontreatment when the infant's disability is more severe or when the life-saving intervention required is more extreme. For example, in the JAMA survey, only $67 \%$ of the respondents would surgically correct the duodenal atresia of an infant with TaySachs disease ${ }^{22}$ (as compared to over $99 \%$ who would perform the surgery on an infant without concomitant disability), and only $60 \%$ would provide kidney dialysis for a Down syndrome infant with chronic kidney failure (as opposed to $89 \%$ who would provide dialysis to an infant without concomitant disability). ${ }^{23}$ Thus, in light of recent evidence of medical attitudes, it may be safe to speculate that while the extent of selective nontreatment may have abated since the early 1980 s, some instances of nontreatment of severely disabled newborns continue to occur.

Although selective nontreatment may not be unique to cases involving HIV infection, several factors peculiar to HIV infection in infants make any analysis of nontreatment decisions in the context of AlDS particularly complex. First, most infected infants are either African-American or Latino, poor, and born into families racked by intravenous drug use (IVDU). ${ }^{24}$ These social factors, in combination with HIV infection, make an infected infant's life particularly vulnerable to devaluation. Second, because of the family disintegration caused by AIDS $^{25}$ and IVDU, medical decisions for a significant number of HIVinfected infants will be made not by the infant's parents, but by the state, in providing foster care, or even by a member of the medical profession. ${ }^{26}$ The compounded minority status of HIV-infected infants,

(1977) (reporting that $46.3 \%$ of responding pediatricians recommended surgery for Down syndrome infant with duodenal atresia).

21. See Glazer, supra note 18 , at 12 . But $\mathrm{cf}$. Koop, supra note 2, at 112 (reasoning that greatest protection for newborns is not federal legislation, but physicians' fear of litigation).

22. See Levin et al., supra note 5, at 2978. Tay-Sachs is an inherited metabolic disorder that may show no manifestations until an affected infant is a few months old. At that point, the infant's muscle tone begins to degenerate progressively, leading to paralysis, spasticity, deafness, blindness, and convulsions. Tay-Sachs infants become vegetative by the age of two or three and die by four or five. See Rhoden, supra note 2, at 1292.

23. See Levin et al., supra note 5, at 2978. For further evidence that pediatricians continue to debate the treatment and nontreatment options for imperiled newborns, see Donna A. Caniano \& George A. Kanoti, Newborns with Massive Intestinal Loss: Difficult Choices, 318 New Eng. J. Med. 703 (1988).

24. See infra Part II.B.

25. See Jill Armstrong \& Edward Bos, The Demographic, Economic, and Social Impact of AIDS, in AIDS in the World 195, 196-97 (Jonathan Mann et al. eds., 1992).

26. See infra Part II.B.2. 
coupled with the relatively high likelihood of nonparental decisionmaking, suggests that the bundle of issues relating to medical decisionmaking for infants infected with HIV is not simply a reprise of the Baby Doe controversy.

The emergence of a population of infants whose social characteristics increase the likelihood that necessary medical treatment may be withheld, particularly in light of the results of the JAMA survey, which indicate that a significant number of health care professionals would advocate such withholding, suggests that the time is ripe to reassess the legal status of selective nontreatment. The recently enacted Americans with Disabilities Act of 1990 (the ADA), ${ }^{27}$ which prohibits virtually all public and economic actors in American life from discriminating on the basis of disability in providing services or benefits, enriches the legal context in which nontreatment of infants with HIV may be analyzed. The ADA's express purpose is to end the pervasive discrimination that persons with disabilities, including HIV infection, currently face, so that all such persons can share fully in the benefits our society offers, including the provision of health services. This legislative focus on equal opportunities for persons with disabilities has implications for our analysis of discriminatory medical treatment decisions.

A reassessment of selective nontreatment in light of the passage of the ADA also provides a useful context for addressing a more fundamental question, namely: Can we speak meaningfully of discrimination based on disability in the context of medical treatment decision-making, and, if so, how can we distinguish illegitimate discrimination from the ethical exercise of sound medical judgment? Although this question has arisen most notably in the past as part of the selective nontreatment debate, the spread of the HlV epidemic, the skyrocketing costs of medical services, and our society's heightened sensitivity to disability discrimination in all aspects of life, among other factors, make it likely that the foregoing question will arise in a variety of patient populations. ${ }^{28}$ For example, decisions made by physicians, hospitals, or state agencies regarding the availability of treatment for either competent or incompetent disabled patients may give rise to claims of discrimination in the recommending or providing of medical treatment. ${ }^{29}$ The task

27. Americans with Disabilities Act of 1990, 42 U.S.C. $\S 12101-12213$ and 47 U.S.C. $\S \S 225,611(1991)$.

28. Cf. Glanz v. Vernick, 750 F. Supp. 39, 41 (D. Mass. 1990) (finding refusal to perform elective surgery on HIV-positive patient to support cause of action for discrimination under Rehabilitation Act); Karen J. Merrikin \& Thomas D. Overcast, Patient Selection for Heart Transplantation: When is a Discriminating Choice Discrimination? $10 \mathrm{~J}$. Health Pol. Pol'y \& L. 7, 14-21 (1985) (examining legal definition of discrimination in choosing heart transplant recipients).

29. As discussed infra Part V1.A, to constitute illegal discrimination under the ADA, treatment recommendations or decisions must be made by public entities or public accommodations as defined by the ADA. Thus, private decision-makers, such as the parents of a newborn or the proxy named under a durable power of attorney for health 
ahead for decision-makers, regulators, and courts will be to assess the legitimacy of medical decisions that take a patient's disability into account.

Thus, while this Article focuses primarily on examining the legality of withholding needed medical treatment from an infant with HIV infection, it ultimately concerns itself with the more fundamental question of how medical decision-makers may legitimately take into account HIV infection or other disabilities in making treatment decisions and recommendations. In other words, how can the concept of disability discrimination be meaningfully applied in the context of individual medical treatment? The scenario hypothesized by the JAMA surveytreatment decisions for an HIV-infected infant who also suffers from an unrelated life-threatening condition-provides a convenient springboard for analyzing the legitimacy of treatment decisions for HIV-infected infants, but the survey's results alone do not address the moral adequacy of justifications for selective nontreatment. A full assessment of this question must consider both the social and medical characteristics of perinatally infected infants ${ }^{30}$ and the legal and ethical legacy left by Baby Doe.

Part II of this Article describes both the medical features of perinatal HIV infection in terms of its incidence, diagnosis, and prognosis, and the social context characteristic of perinatal infection. Part III briefly reviews the controversy generated by the Baby Doe case and the federal responses, which took the form of regulations promulgated under section 504 of the Rehabilitation Act of 1973 and the enactment of the Child Abuse Amendments of 1984. It then considers to what extent the legal issues raised by Baby Doe have been addressed by the legal and medical communities. In light of the lack of resolution achieved by legal responses to Baby Doe, Part IV turns to ethical discussions of selective nontreatment for insights into a normative basis for regulating the practice. There, although ethicists and other commentators have failed to reach complete consensus on what moral standards should guide decision-making for disabled infants, we will find that many commentators agree that treatment decisions should be made in the best interests of a disabled infant, based upon an individualized assessment of the infant's condition and proguosis.

In Parts V and VI, this Article examines whether the legal ap-

care, would not be covered. Nor would the decisions made by a competent disabled patient with respect to her own treatment be covered. It is entirely conceivable, however, that discriminatory treatment recommendations made by a disabled patient's caregiver, could be covered by the ADA. For example, a physician who recommends a screening test for prostate cancer for all his male patients over a certain age except for those who are also HIV positive makes discriminatory treatment recommendations, as opposed to treatment decisions.

30. Perinatal transmission of HIV occurs from mother to fetus before or during birth. See infra text accompanying notes 35-36. 
proaches by which the federal government sought to regulate selective nontreatment in the mid-1980s apply to medical treatment decisions for infants with HIV infection, and, if so, whether these approaches adequately address the ethical concerns raised by selective nontreatment. Part V asserts that although the Child Abuse Amendments of 1984, in which the government approached selective nontreatment as a problem of child abuse and neglect, appear to prohibit the kinds of nontreatment hypothesized in the JAMA survey, the problems of enforcing that legislation are likely to be particularly acute in those cases when nontreatment of HIV-infected infants is most ethically problematic. The government's second approach to Baby Doe-treating selective nontreatment as a problem of disability discrimination-appears to provide a more satisfying response to the issues raised by the growing numbers of HIV-infected infants. Part VI focuses on the ADA as a vehicle for addressing selective nontreatment problems and proposes that the ADA be interpreted to apply to medical decision-making generally in a way that both recognizes and respects the complexity of the decisionmaking process, but that condemns decisions distorted by prejudice and misconceptions of disabilities.

Ultimately, this Article concludes that disability discrimination law should be interpreted to apply to medical treatment decision-making and, as so interpreted, provides a vehicle for addressing the nontreatment of HIV-infected infants in a fashion that is consistent with the standards developed in the ethical ferment prompted by Baby Doe. Reading the ADA as prohibiting nontreatment decisions for infants based on the mere existence of HIV infection and, more generally, as prohibiting treatment decisions or recommendations for any patient based on the mere existence of a disability reinforces, rather than intrudes on, existing ethical standards of the medical profession. Ideally, drawing on our ethical experience to inform our reading of the ADA will allow us to accord HIV-infected infants and all persons with disabilities protection against discrimination in medical decision-making and to avoid creating between patients and decision-makers the adversarial relationships that a civil rights approach may sometimes engender. If learning from experience enables us better to protect the true interests of the growing number of infants born infected with HIV and, indeed, all patients with disabilities, perhaps Baby Doe's death will not have been in vain.

\section{Placing the Question in Context}

\section{A. The Medical Context}

1. Perinatal Transmission of HIV and Diffculties of HIV Detection.Although AIDS entered the public's consciousness as a disease affect- 
ing homosexual and drug-using men ${ }^{31}$ and although the total number of infected women in the United States remains relatively small, the rate of increase of new cases of AIDS among women in the United States is now greater than among men. ${ }^{32}$ As HIV infection among women increases, so does infection among children. It is estimated that more than three quarters of the women diagnosed with AIDS $^{33}$ in the United States are of childbearing age, and a 1989 study estimated the incidence of HIV infection in women actually giving birth in that year to be 1.5 women out of 1000 nationwide. ${ }^{34}$

Although perinatally acquired AIDS was first diagnosed over a decade ago, much about the exact mechanism and timing of the transmission of HIV from the mother to the fetus or newborn remains a mystery. Medical research suggests that transmission may occur during pregnancy by transplacental passage of the virus, during delivery by contact with maternal blood or genital tract secretions, and following birth by breastfeeding. The exact nature of these modes of transmission and their relative importance have not yet been determined. ${ }^{35}$ Whatever the mode of transmission, not all infants born to HIV-posi-

31. See Karposi's Sarcoma and Pneumocystis Pneumonia Among Homosexual Men-New York City and California, MMWR, July 3, 1981, at 305.

32. See Margaret C. Heagarty \& Elaine J. Abrams, Caring for HlV-lnfected Women and Children, 326 New Eng. J. Med. 887, 887 (1992). As of 1992, 22,000 women with AlDS have been reported to the federal Centers for Disease Control. See id. In July 1992, officials of the World Health Organization reported that worldwide, women are becoming infected with HIV about as frequently as men and that by the year 2000 , most new infections are expected to be in women. See Lawrence K. Altman, Women Worldwide Nearing Higher Rate for AIDS than Men, N.Y. Times, July 21, 1992, at B8; see also Lawrence K. Altman, AIDS Cases from Sex on Rise for Women, N.Y. Times, July 23, 1993, at A12; Boyce Rensberger, HIV Increasing Faster Among Young Women, Report Says, Boston Globe, July 29, 1993, at 15 (citing newly released United Nations Development Program report that women between ages 15 and 25 represent $70 \%$ of the 3000 women a day who contract HIV).

33. HIV has a relatively lengthy incubation period; the period from infection to the development of AIDS ranges from several years up to a decade. See John Modlin \& Alfred Saah, Public Health and Clinical Aspects of HIV Infection and Disease in Women and Children in the United States, in AIDS, Women and the Next Generation 29, 39 (Ruth R. Faden et al. eds., 1991) (reporting median time of 8 to 11 years from infection to the development of AIDS in homosexual men). As a result, any reporting of diagnosed AIDS cases will greatly underrepresent the number of persons infected with HIV.

34. See Marta Gwinn et al., Prevalence of HIV Infection in Childbearing Women in the United States: Surveillance Using Newborn Blood Samples, 265 JAMA 1704, 1704 (1991). As the title of this article suggests, HIV prevalence studies among childbearing women usually detect maternal antibodies to HIV by assaying dried blood specimens routinely collected from newborns. The 1.5 per 1000 figure is a nationwide estimate; prevalence estimates vary widely by both geographic location and racial groups. See infra text accompanying notes 81-83.

35. See European Collaborative Study, Risk Factors for Mother-to-Child Transmission of HlV-1, 339 Lancet 1007, 1011 (1992) [hereinafter Risk Factors]; Modlin \& Saah, supra note 33, at 40-41. 
tive women will be infected with the virus; studies suggest that approximately one in three will be infected. ${ }^{36}$ Prompt determination of whether an infant born to an HIV-infected mother is itself infected with the virus, however, has proved quite difficult. Serologic tests ${ }^{37}$ generally used to detect HIV antibodies in blood, when performed on an infant less than fifteen months old, may reflect passively acquired maternal antibodies to the virus and thus produce a false positive result. ${ }^{38}$ Consequently, in diagnosing HIV infection in younger infants, physicians have had to rely either on the presence of the virus in the infant's blood or tissue or on symptoms meeting the CDC's definition of pediatric AlDS. ${ }^{39}$ Although recent studies demonstrate the success of the

36. Although studies have reported a risk of infection among infants born to HIVinfected women ranging from $7 \%$ to $39 \%$, see, e.g., Risk Factors, supra note 35 , at 1008 , experts currently believe that the overall estimated vertical mother-to-child transmission rate approximates $20 \%$ to $30 \%$. See Steven A. Miles et al., Rapid Serologic Testing with Immune-Complex-Dissociated HIV p24 Antigen for Early Detection of HIV Infection in Neonates, 328 New Eng. J. Med. 297, 297 (1993). The study described in Risk Factors found an overall rate of vertical transmission of only $\mathrm{I} 4.4 \%$, but found that the risk of transmission was greatest $(31 \%)$ for infants born to women already diagnosed with AIDS. See Risk Factors, supra note 35, at 1008-09. A linkage between full-blown maternal AIDS and a heightened transmission rate, if confirmed, would suggest that the responsibility for caring for a large proportion of infants so infected will be borne by someone other than the mother in light of her inability to care for the infant. See infra Part II.B.

37. The enzyme immunoassay (EIA), also called the enzyme linked immunosorbent assay (ELISA), is the most common serologic test for antibodies to HIV in serum or plasma. The EIA first screens test sera as single specimens. If the test result is positive, the test is repeated twice more from the same serum specimen. The serum specimen is deemed reactive by EIA if at least one of these two repeat tests is positive; otherwise, the serum specimen is deemed negative.

If the serum specimen is deemed reactive by EIA, a Western blot is usually done to confirm the EIA results. The Western blot is a more virus-specific test. It can determine whether the antibody that reacted in the EIA is specific for HIV antigens or whether it cross-reacted with nonviral components of the EIA system. Confirmation of EIA results by the Western blot is determinative of HIV infection. See Modlin \& Saah, supra note 33 , at $32-37$.

38. See Russell B. Van Dyke, Pediatric Human Immunodeficiency Virus Infection and the Acquired Immunodeficiency Syndrome, 145 Am. J. Diseases Children 529, 530 (I99I). In addition to the problem with false positives, serologic testing may also produce false negative results in some infected children whose immune systems are so debilitated by the virus at an early age that they are never able to produce HIV antibodies that would be detected. See Cheryl P. Weinstock, Children with AIDS, FDA Consumer, Oct. 1990, at 8 . In contrast to these explainable false negatives, a few rare and unexplained cases have been reported of children who show no signs of being immuno-compromised and whom serologic tests show not to be infected, but who become ill some time later. See AIDS-Infected Babies, 5 AIDS Report, Feb. I992, at I-2.

39. See Oleske, AIDS in Our Children, supra note 4, at 439 . The clinical features of pediatric AIDS typically include growth failure, developmental delay, hepatosplenomegaly, lymphadenopathy, recurrent bacterial infections, and chronic Candida infections. In many children, the virus manifests itself in the form of chronic parotitis (inflammation and swelling of one or more mump glands), pneumonias, and 
technique of polymerase chain reaction in detecting HIV infection in infants less than a month old, ${ }^{40}$ and a recent report indicates that a new rapid assay for detecting a specific HIV antigen may be of value in diagnosing HIV in neonates, ${ }^{41}$ the reliability of these means of detection is not yet established, and their use is likely to remain limited in the short run. 42

Because the exact rate of perinatal transmission of HIV remains unknown and diagnosis of the infection in young infants remains problematic, any estimate regarding the number of young children infected with HIV and projections regarding future numbers must be tentative. ${ }^{43}$ As of June 1993,4710 cases of pediatric AIDS had been reported to the CDC, of which 4121 cases, or $87.5 \%$, were attributable to perinatal infection. ${ }^{44}$ This number, however, vastly understates the prevalence of HIV infection among children: experts estimate that for each reported case of AIDS, another two to ten children are infected

thrombocytopenia (persistent decrease in the number of blood platelets, usually associated with hemorrhaging). See Irah L. Hand et al., Human Immunodeficiency Virus Seropositivity in Critically Ill Neonates in the South Bronx, 11 Pediatric Infectious Disease J. 39, 41 (1992); Van Dyke, supra note 38, at 529.

40. See Anne Marie Comeau et al., Detection of HIV in Specimens from Newborn Screening Programs, 326 New Eng. J. Med. 1703, 1703 (1992).

41. See Miles et al., supra note 36 , at 298-301.

42. See id. at 301. Cf. Task Force on Pediatric AIDS, Perinatal Human Immunodeficiency Virus (HIV) Testing, 89 Pediatrics 791, 791 (1992) (recommending that the use and interpretation of PCR tests be limited to those research centers experienced in their evaluation).

43. Cf. Robert H. Parrott, Childhood Human Immunodeficiency Virus Infection: The Spectrum of Costs, $4 \mathrm{~J}$. Acquired Immune Deficiency Syndromes 122, 122-24 (1991) (reporting estimates of the prevalence and number of new cases of HIV infection among children).

44. See Centers for Disease Control, HIV/AIDS Surveillance Report, July 1993, at 3, 6 [hereinafter CDC, Surveillance Report]; cf. Margaret C. Heagarty, Pediatric Acquired Immunodeficiency Syndrome, Poverty, and National Priorities, $145 \mathrm{Am}$. J. Diseases Children 527, 527 (1991). The percentage of HIV-infected children who acquire the infection perinatally is expected to increase as universal blood screening programs prevent further transmission to children through blood transfusions. This trend is reflected in CDC reports. Of the first 100,000 AIDS cases reported in the United States from 1981 to $1989,81 \%$ of 1683 children with AIDS were born to women with or at risk for HIV infection. Of the second 100,000 , which were reported from September 1989 to November 1991, 87\% of the 1702 children diagnosed with AIDS were born to women with or at risk for HIV. See Centers for Disease Control, The Second 100,000 Cases of Acquired Immunodeficiency Syndrome-United States, 267 JAMA 788, 788 (1992) [hereinafter CDC, The Second 100,000 Cases].

Another possible mode of transmission of HIV to the pediatric population is through child sexual abuse by an HIV-positive attacker. See George A. Gellert et al., Situational and Sociodemographic Characteristics of Children Infected with Human Immunodeficiency Virus from Pediatric Sexual Abuse, 91 Pediatrics 39, 39 (1993) (finding that although current statistics of transmission are unknown, HIV transmission through sexual abuse may emerge as a "minor but significant" mode of transmission to children in the future). 
with HIV. ${ }^{45}$ Despite our ignorance regarding the number of children infected with HIV who have not developed HIV-related symptoms or AIDS, one conclusion seems unavoidable: in the absence of an effective method of preventing perinatal transmission of HIV ${ }^{46}$ or effective measures, whether educational or coercive, for identifying and limiting reproduction by women infected with HIV, ${ }^{47}$ the rate of increase in perinatally infected infants seems likely to continue to rise, following the infection rate of women. ${ }^{48}$

2. The Prognosis for Perinatally Infected Infants.-Only several years ago, the medical community expected most infants perinatally infected with HIV to become ill and die "an agonizing death" within a few years. ${ }^{49}$ Recent studies, however, suggest a brighter prognosis: some children are being identified who have lived their first decade with few

45. See CDC, Surveillance Report, supra note 44, at 6; cf. Josephine Gittler \& Merle McPherson, HIV Infection Among Women of Reproductive Age, Children, and Adolescents: An Introduction, 77 Iowa L. Rev. 1283, 1294 (1992) (citing Secretary's Work Group on Pediatric HIV Infection and Disease, U.S. Dep't Health and Human Servs., Final Report 12 (Nov. 1988)).

46. Incomplete understanding of the timing and mechanism of perinatal transmission of HIV and of why only one in three infants born to HIV-infected women become infected themselves currently limits the ability of researchers to devise a method of preventing perinatal transmission. See Van Dyke, supra note 38, at 531 .

47. 1ssues regarding screening women of reproductive age for $\mathrm{HIV}$ and its implications for public health and reproductive freedom have been the subject of much debate in both legal and medical literature. See infra note 81 . Related issues are raised by proposals for testing newborns for the HIV antibody, since at this time serologic testing of the infant is essentially a test of the mother's serologic status. See Task Force on Pediatric AIDS, supra note 42, at 792.

48. Because factors such as intravenous drug use, poverty, transience, lack of access to family planning services, prostitution, and cultural influences may affect the birth rates of women infected with $\mathrm{HIV}$, it would be unwise simply to assume that an increased infection rate among women of childbearing years will result in a parallel increase in the number of perinatally infected infants. Several studies, however, have indicated that women with knowledge of their infection are not significantly less likely than uninfected women to become pregnant or to carry their pregnancies to term. See, e.g., Reproductive Behavior in HIV-Infected Women, 46 Am. Fam. Physician 1804, 1804 (1992) (quoting study cited in Obstetrics \& Gynecology which found that $18.8 \%$ of seronegative women, as compared to $23 \%$ of seropositive women, had subsequent live births); Peter A. Selwyn et al., Knowledge of HIV Antibody Status and Decisions to Continue or Terminate Pregnancy Among Intravenous Drug Users, 261 JAMA 3567, 3568 (1989) (reporting results of JAMA study which found that $50 \%$ of seropositive and $56 \%$ of seronegative pregnant women interviewed chose to carry their pregnancy to term). Religious and cultural values, as well as poor access to contraceptive and abortion services, may help to shape some women's decisions to give birth even though they are infected with HIV. See Taunya L. Banks, Women and AIDS-Racism, Sexism, and Classism, 17 N.Y.U. Rev. L. \& Soc. Change 351, 375 \& n.132, 380-81 (1989). See also infra text accompanying note 211.

49. See Weinstock, supra note 38, at 8-9 ("According to CDC, the average age of diagnosis of AIDS in infants is 9 months. Often, they die shortly thereafter."); see also Children and HIV lnfection: Hearings Before the Human Resources and Intergovernmental Relations Subcomm. of the House Comm. on Governmental Operations, 10 lst Cong., 1st Sess. 20 (1989) [hereinafter Children and HIV Hearing] 
or no apparent symptoms of HIV infection, and officials at the CDC now say that a majority of perinatally infected children survive beyond age five. ${ }^{50}$ Evidence that perinatally infected infants may enjoy years of active, relatively unimpaired life if provided with aggressive medical treatment highlights the human costs that can result from a decision not to provide medical treatment based on a patient's disability.

Although the threat posed to some infants by HIV infection may be less immediate than previously believed, the frequent coincidence of perinatal HIV infection with other health risks, such as exposure to other sexually transmitted diseases and to drugs, ${ }^{51}$ may create treatment dilemmas in early infancy. HIV-infected infants typically display no symptoms of infection in the weeks following birth, ${ }^{52}$ and one study suggests that a woman's asymptomatic HIV infection in itself creates no additional risk of an adverse pregnancy outcome such as low birth weight or prematurity. ${ }^{53}$ Nonetheless, a disproportionately large number of infants perinatally exposed to HIV need critical medical care at and following birth, apparently as a result of the coincidence of other health risks. ${ }^{54}$

(statement of Gwendolyn V. Scott on behalf of the Pediatric AIDS Coalition) ("HIV-1 infection in children is primarily a disease of infants and toddlers.").

50. See Mireya Navarro, Growing Up in the Shadow of the AIDS Virus, N.Y. Times, Mar. 21, 1993, at 33.

51. See Hand et al., supra note 39, at 41 (finding that in study of HIV seropositivity of infants born at Bronx Lebanon Hospital, maternal drug use played a "major role" in the need of critical care for the infants).

52. See Hermann Mendez \& Jose E. Jule, Care of the Infant Born Exposed to Human Immunodeficiency Virus, I7 Obstetrics \& Gynecology Clinics N. Am. 637, 638 (1990) ("Characteristically, the newborn who subsequently is found to be infected is asymptomatic during the nursery stay.").

53. See Peter A. Selwyn et al., Prospective Study of Human Immunodeficiency Virus Infection and Pregnancy Outcomes in Intravenous Drug Users, 261 JAMA 1289, 1291-94 (1989). This study surveyed women in a methadone program, all of whom were current or former IV drug users. The study compared the pregnancy outcomes of HIV seronegative women with the outcomes of seropositive women. The results suggest that the HIV status of the mother by itself does not contribute to complications and that any complications noted in the HIV seropositive group were usually attributable to active IVDU prior to delivery. See id. at 1292. It is unclear whether the study's findings are generalizable to non-IVDU populations of HIV-infected women.

54. See Hand et al., supra note 39 , at 4 I. In this study, conducted at a 600 -bed hospital providing comprehensive care to an indigent population with multiple risk factors for HIV infection, the incidence of HIV-positive infants was 3.17\%, but the incidence of HIV-positive infants among the neonatal intensive care unit population was four times that figure. See id. at 40-41. Researchers identified several factors associated with the HIV-positive infants' need for critical care, including prematurity, low birth weight, drug withdrawal, and microcephaly. See id. See also Levin et al., supra note 5, at 2976 ("Although infection with [HIV] does not appear frequently to lead to illness during the neonatal period, many infants who are infected with HIV are also at high risk for premature delivery and other serious conditions that lead to admission to an NICU."). These increased risks are primarily associated with maternal drug use, whose association with maternal seropositivity is discussed infra text accompanying notes 55-57. Some conditions suffered by HIV-positive infants, however, 
The primary coincident health risk for HIV-infected infants is prenatal exposure to drugs. Over two-thirds of the cases ${ }^{55}$ of maternally transmitted HIV infection are associated with intravenous drug use, either because the mother became infected through her own IVDU ${ }^{56}$ or because she was infected through heterosexual transmission from a partner engaged in IVDU. ${ }^{57}$ This linkage between maternally transmitted HIV and IVDU has dismal implications not only for the family's ability to care for a baby, but also for the infant's physical condition. Women who use drugs during pregnancy are more likely to give birth to low birth weight babies and to suffer perinatal complications, either of which may create serious medical problems for the newborn. In addition, the newborn may require intensive medical care for drug withdrawal. 58 Thus, maternal prenatal drug use not infrequently takes a heavy toll on infants infected with HIV and may set the stage for selective nontreatment by giving rise to a condition requiring life-saving treatment for the infant. 59

are "classical signs of congenital infection." These include low birth weight, small size for gestational age, hepatosplenomegaly, thrombocytopenia, jaundice, anemia, and elevated liver function tests. See Oleske, AIDS in Our Children, supra note 4, at 444.

55. This fignre has been broken down by race and ethnic group as follows: of perinatally acquired AIDS cases among African-American and Hispanic infants, $73 \%$ were associated with IVDU; of such cases among white infants, $69 \%$ were associated with IVDU. See Modlin \& Saah, supra note 33, at 31.

56. Based on AIDS cases reported to the CDC in 1990, $47.6 \%$ of women with AlDS reported a history of IVDU. See Centers for Disease Control, Update: Acquired Immunodeficiency Syndrome-United States 1981-1990, 265 JAMA 3226, 3226 (1991) [hereinafter CDC, Update 1981-1990].

57. See Modlin \& Saah, supra note 33 , at 31 . Until the late 1980 s, the vast majority of IV drug users were heroin addicts. Since that time, however, an increasing number are cocaine addicts who inject the drug ten or more times daily. The frequency of injection by cocaine addicts places them at greater risk of HIV infection from shared needles than heroin addicts, who usually inject the drug only three or four times daily. See Children and HIV Hearing, supra note 49, at 194 (statement of Charles P. Schuster, Director, Nat'l Institute on Alcohol, Drug Abuse and Mental Health Admin.). In addition, persons using crack cocaine or other mind-altering substances have a disproportionately high incidence of HIV infection resulting from their increased sexual activity. See Constance M. Ryan \& Jean Emery, Meeting the Challenge of HIV Infection in Family Foster Care 19 (199I).

58. See Hand et al., supra note 39 , at 41 .

59. Although I have found no figures regarding what percentage of all HIVinfected infants suffer unrelated complications, one study suggests that infants born to HIV-infected women are siguificantly more likely than other infants to suffer a complication requiring intensive care. See id. at 40-41 (finding incidence of HIV seropositivity among all infants born at hospital in South Bronx to be $3.17 \%$, while incidence of seropositivity in hospital's NICU was $11.6 \%$ ). These complications may be linked to maternal drug use during pregnancy, to the presence of other sexually transmitted diseases, and to inadequate prenatal care. See id. at 41 . The dearth of figures regarding the percentage of HIV-positive infants suffering other complications may be attributable in part to the common failure in the past to identify an infant as HIV positive during the neonatal period. See Levin et al., supra note 5, at 2980-81.

The negative effects of prenatal maternal use of cocaine and of heroin have been 
With respect to the clinical course of the infant's HIV infection, however, recent studies suggest that prognoses may vary depending both on when the infant or child first manifests signs of HIV infection and on what the presenting clinical signs are. ${ }^{60}$ For example, infants whose HIV infection is first manifested by Pneumocystis carinii pneumonia (PCP) tend to be diagnosed at an early age and to survive for only a short time, while those who first present with lymphocytic interstitial pneumonitis (LIP) tend not to develop symptoms until around the age of two and to live several years longer. However, survival figures even for infants diagnosed with PCP appear to be improving, possibly as a result of more aggressive therapy and the use of prophylactic antibiotics. ${ }^{61}$

\section{Despite the tentative nature of current findings regarding prognos-}

documented. Physicians have found a high incidence of prematurity and low birth weight among cocaine babies. See John L. Goldman, Cocaine's Tiniest Victims: A Struggle from the Start, L.A. Times, May 30, 1988, at 1, 16. Fetal growth, including head and brain size, may be impaired, strokes and seizures may occur, and malformations of the kidneys, genitals, intestines, and spinal cord may develop. See John Langone, Crack Comes to the Nursery, Time, Sept. 19, 1988, at 85. Cardiovascular abnormalities, including atrial and ventricular septal defects, have also been documented. See Steven E. Lipshultz et al., Cardiovascular Abnormalities in Infants Prenatally Exposed to Cocaine, 118 J. Pediatrics 44, 44-49 (1991). Additionally, these children experience speech and hearing problems, dyslexia, "emotional problems, aggressiveness, organization and language problems, difficulties with personal relationships and trouble experiencing pleasure and other emotions." Peggy McCarthy, Prenatal Drug Exposure Shadows Children in School, N.Y. Times, Mar. 24, 1991, $\S 12 \mathrm{CN}$, at 1 . It has also been observed that heroin babies endure classic withdrawal symptoms: they are irritable and jittery; they scream and scrape their elbows and knees raw in their restlessness. See Mothers' Drug Use Causes An Epidemic Of Damaged Babies, Chi. Trib., Sept. 5, 1988, at 15.

60. Pediatric.AIDS experts now have identified three distinct patterns of clinical courses followed by pediatric AIDS cases. In the first type of case (which describes up to $25 \%$ of perinatally infected infants), the child develops symptoms of infection within his first 18 months, and the disease progresses quickly to death. In the second type of case, the virus attacks the child's immune system less aggressively so that the child may suffer milder or transient symptoms and live until he is three to five years of age. Finally, experts are just now recognizing that a number of children infected from birth are living with few or no symptoms for many years; these children may not even be diagnosed with AIDS until they are nine or older. Experts suggest that the different courses of pediatric AlDS cases may be related to factors such as the viral strain carried and at what point during preguancy or birth transmission occurred. See Navarro, supra note 50, at 33, 36 .

61. See Pauline Thomas et al., Trends in Survival for Children Reported with Maternally Transmitted Acquired Immunodeficiency Syndrome in New York City, 1982 to 1989,11 Pediatric Infectious Disease J. 34, 38 (1992) (noting that although the improvement in survival following biopsy-proved PCP must be reviewed with caution, the improved survival was "undoubtedly real"); P.A. Tovo et al., Prognostic Factors and Survival in Children with Perinatal HIV-1 Infection, 339 Lancet 1249, 1252 (1992). Antibiotics can be used both prophylactically to prevent the development of opportunistic infections such as PCP and therapeutically to combat infections once developed. Therapies for pediatric AIDS also include antiviral drugs and immunotherapy in combination with supportive nutrition. 
tic factors and the effectiveness of existing therapies for perinatally infected infants, three important conclusions flow with some certainty from the medical literature: First, survival in cases of maternally transmitted HIV remains markedly variable. ${ }^{62}$. Second, children with perinatally acquired HIV infection are living longer than previously expected. ${ }^{63}$ Third, a physician cannot currently predict, in advance of clinical manifestations of HIV infection, what a given infant's clinical course and survival will be. ${ }^{64}$

This combination of improving, but variable, survival with prognostic uncertainty has significant implications for analyzing the propriety of selective nontreatment of HIV-infected infants. Because a physician treating a young infant with HIV infection usually cannot reliably forecast the infant's prognosis, the physician or other decisionmaker cannot easily balance the benefits of providing life-saving treatment against the risks and burdens of providing that treatment. As a result, any attempt to assess what treatment is in the best interests of the infant ${ }^{65}$ must remain speculative. In light of this uncertainty, erring on the side of providing treatment that might enable a child to enjoy many years of life seems preferable to erring on the side of letting the infant die as a result of nontreatment.

\section{B. The Social Context}

For most people who ever have the occasion to read a law review article, imagining with any accuracy the world into which most perinatally infected infants are born is probably difficult: The setting is urban and poor. The family is ravaged by intravenous drug use, AIDS,

62. See Thomas et al., supra note 61 , at 38 (finding a "marked variability" in survival from birth for children with maternally transmitted AIDS in New York City to be supported by other studies).

63. See id.; see also Nancy Hutton \& Lawrence S. Wissow, Maternal and Newborn HIV Screening: Implications for Children and Families, in AIDS, Women and the Next Generation, supra note 33, at 105,108 (citing report of perinatally infected children living to I0 or I1 years); Navarro, supra note 50 , at 33 (reporting infected children as old as 14); Tovo et al., supra note 61 , at 1252 (showing approximately $70 \%$ of HIVinfected children in study alive at 6 years). It is unclear to what extent an improvement in survival figures reflects more effective prophylaxis and therapy as opposed to reflecting a time lag in diagnosing cases of perinatally acquired AIDS in older children. Cf. Mendez \& Jule, supra note 52, at 638 (predicting that as more cases of AlDS are diagnosed in older children, the average incubation time will increase); Thomas et al., supra note 61 , at 38 (finding that at least part of improved survival rates must be attributed to earlier diagnosis).

64 . See Hutton \& Wissow, supra note 63 , at 107 ; see also Tovo et al., supra note $6 \mathrm{I}$, at 1252 (suggesting that because children at risk for those infections that cause most early pediatric AIDS deaths cannot be prospectively identified, prophylactic measures in all at-risk infants may be needed). For further discussion of the clinical course and manifestations of pediatric HIV infection, see generally Gittler \& McPherson, supra note 45 , at 1295-98.

65. The best interests standard and alternative standards for guiding treatment choices for infants are discussed infra in Part IV. 
or both, and may not have the financial, social, or emotional wherewithal to care for the baby. The infant itself may be addicted to drugs even before birth and he or she belongs to a minority group whose members frequently suffer discrimination. This is not the most auspicious of beginnings.

While this combination of social factors makes most perinatally infected infants particularly vulnerable to decisions to withhold needed medical treatment, it is ultimately the mother's (and perhaps father's) HIV infection, either alone or in combination with familial drug use, that most often triggers a separate factor figuring siguificantly in our analysis of nontreatment: involvement of the state in making medical decisions for perinatally infected infants. The coexistence of familial HIV infection and drug use with an infant's HIV infection means that at some point the family may become either unable or unwilling to provide the special care the infant needs. ${ }^{66}$

Consequently, many infants and children with perinatally acquired HIV infection at some point need foster care placement. ${ }^{67}$ Finding foster families willing to care for an HIV-infected infant can be difficult,

66. See Phyllis Gurdin \& Gary R. Anderson, Quality Care for Ill Children: AIDSSpecialized Foster Family Homes, 66 Child Welfare 291, 291 (1987). Cf. Heagarty \& Abrams, supra note $\mathbf{3 2}$, at 888 (reporting estimate from New York City Department of Health that in that city alone, some 40,000 children may be orphaned by AIDS in the 1990s); Hutton \& Wissow, supra note 63, at 115 (noting that belief that an infant is HIV infected may increase the chance that she will be abandoned or rejected after birth); Van Dyke, supra note 38, at 530 ("As the HIV infection progresses in the child's parents, they are unable to care adequately for themselves and their child.").

A mother whose dependency on illegal drugs leaves her incapable to care adequately for her child may recruit assistance from members of the child's extended family. If the family learns that the child is HIV positive, however, this caregiving arrangement may be jeopardized, and the child may be forced into the formal foster care system. See Hutton \& Wissow, supra note 63, at 114.

67. See Task Force on Pediatric AIDS, Infants and Children With Acquired Immunodeficiency Syndrome: Placement in Adoption and Foster Care, 83 Pediatrics 609, 609 (1989); see also J. Curtis McMillen \& Victor Groze, Child Welfare Policies Affected by the Difficulty in Diagnosing HIV Infection in Infants and Young Children, 6 AIDS \& Pub. Pol'y J. 59, 59 (1991) (estimating that $25 \%$ to $33 \%$ of infants born with HIV infection will not receive care from their biological parents); Oleske, AIDS in Our Children, supra note 4 , at 439 (estimating that more than $30 \%$ of pediatric AIDS cases are in foster care).

HIV-positive children are put in state custody under a variety of circumstances. The unflattering popular image of a drug dependent mother abandoning her infant to feed her habit suggests one reason why HIV-positive infants may fall under the state's care, but it is by no means the only way that such infants are taken into the foster care system. For example, a child may be placed in a transitional home for children with HIV when its mother, suffering from the final stages of AIDS, is taken to the hospital. Or, what is considered "abandonment" may represent an effort by the mother to insure that her child will receive the nutrition and medical care that she is financially unable to provide. See Field Hearing on the Abandoned Infants Assistance Act: Hearing Before the Subcomm. on Select Education of the House Comm. on Education and Labor, Newark, New Jersey, May 10, 1991, at 25-26 [hereinafter AIAA Hearings]. 
and as a result, infants left in a hospital nursery by their mothers may stay in the hospital longer than is medically necessary. ${ }^{68}$ For these "boarder babies," the hospital fills the gap left by a lack of foster care. ${ }^{69}$

Options for placing an infant or child with HIV infection depend on what programs are available locally and on the child's legal status with respect to its natural parents; possibilities may include placement in a temporary shelter or group care facility, kinship care, or placement with a regular or specially trained foster family. ${ }^{70}$ A number of programs designed to address the special foster care needs of HlV-positive infants and children have been developed, ${ }^{71}$ but for the foreseeable future it is likely that the number of infected children in need of placement will remain greater than the number of available homes. ${ }^{72}$

The removal of approximately $30 \% 73$ of perinatally infected infants and children from parental custody and their placement in some kind of foster care raises the question of who has legal authority to consent to medical treatment for these children. Are the foster parents, the state child welfare agency, the family court, or the biological parents responsible for making treatment decisions? Although there

68. See McMillen \& Groze, supra note 67, at 59; Van Dyke, supra note 38, at 530.

69. See, e.g., James D. Hegarty et al., The Medical Care Costs of Human Immunodeficiency Virus-Infected Children in Harlem, 260 JAMA 1901, 1903 (1988) (reporting that at Harlem Hospital medically unnecessary social days accounted for $20 \%$ of the total cost of care for children with HIV infection). Although the boarder baby problem has received the most public attention in the context of drug-exposed infants, the population also includes a significant number of HIV-positive infants. See AIAA Hearings, supra note 67, at 60 (reporting Child Welfare Leagne of America survey findings that $69 \%$ of babies boarding in surveyed hospitals were boru to drug dependent mothers and that in many cases one or both of the parents of the boarding infants were HIV positive or had AIDS); Hutton \& Wissow, supra note 63, at 114 (estimating that 1 in 10 boarder babies in New York City may be infected with HIV).

70. See AIAA Hearings, supra note 67, at 65-67; McMillen \& Groze, supra note 67, at 61-62. Although permanent adoption is also an option, it is infrequently used for an abandoned HIV-infected infant, both because courts and child welfare agencies may be loath to sever ties with a living biological parent and because prospective adoptive parents may be fearful of making a commitment in the face of the infant's special medical needs. See id. Even when an infant has been abandoned, proceedings to terminate parental rights are frequently contested. Although termination could theoretically take place in about 18 months, depending on the jurisdiction, the process usually takes about three years. See id. at 67.

71. See Abigail English, The HIV-AIDS Epidemic and the Child Welfare System: Protecting the Rights of Infants, Young Children and Adolescents, 77 Iowa L. Rev. 1509 , 1547-48 (1992). In addition, it has been suggested that child welfare agencies operate small boarding homes for HIV-positive children who are too sick or disabled to receive care in a foster home so that those children will have an alternative to long hospitalizations. See Gurdin \& Anderson, supra note 66, at 301.

72. See Gurdin \& Anderson, supra note 66, at 301 .

73. See supra note 67 and accompanying text. If we estimate that currently approximately 12,000 children in the United States have been perinatally infected, see supra text accompanying notes $44-45$, then we can estimate that 3600 of these children are likely to end up in some form of foster care. 
seems to be no uniform answer to this question, it appears that in most states, the commitment of a child to the Department of Social Services does not necessarily deprive the parents of medical guardianship of their child, so that parents may continue to have some voice in medical decision-making. ${ }^{74}$ Nonetheless, as a practical matter, in the frequent cases involving parents who are seriously ill themselves or involved in IVDU, the parents may not play an active role. In addition, although most states allow foster parents to consent to routine medical care, the appropriate decision-maker regarding nonroutine care is less clear. ${ }^{75}$ What does seem clear, however, is that when an infant's biological parents are either legally or practically disabled from making treatment decisions for an infant in foster care, some agent of the state must assume that responsibility.

As if this social landscape were not disheartening enough, fully grasping how the deck is stacked against most perinatally infected infants requires us to consider the broader context in which questions involving their medical treatment will be addressed. First, decisions regarding infected infants' medical care will be made under conditions of scarcity, in terms of both medical and social service resources. The AIDS epidemic has placed an enormous burden on federally and state funded medical programs at a time when expenses for those programs were already soaring. ${ }^{76}$ Moreover, child welfare agencies already stretched to their limits by the need to place infants born to drug-addicted parents are unlikely to be able to provide zealous advocacy for HIV-positive infants' access to aggressive medical care. ${ }^{77}$

74. See Deborah Weimer, Beyond Parens Patriae: Assuring Timely, Informed, Compassionate Decisionmaking for HIV-Positive Children in Foster Care, 46 U. Miami L. Rev. 379, 381 (199I).

75. See Jonathan D. Moreno, Foster Parents as Surrogates for Infants and Young Children, 58 Mt. Sinai J. Med. 393, 396 (1991).

76. Former HHS Secretary Louis Sullivan estimated that, by the end of $1993, \$ 17$ billion in federal funds will have been spent on AIDS-related programs. This expenditure is more than that spent for any other infectious disease. On research and prevention, only cancer-related programs receive more federal funds. See Statement by Health and Human Services Secretary Louis Sullivan, Fed. News Serv., Sept. 25, 1992, available in LEXIS, Nexis Library, Wire file. Each year $\$ 300$ million in federal funding is distributed to hundreds of community organizations for AIDS education. See Brenda Wilson, All Things Considered: AIDS Advertising Campaign Unveiled by HHS (National Public Radio broadcast, Mar. 26, 1992).

Federal funds are allocated to states through a formula tied to the number of reported AIDS and HIV cases. Cities with more than 2000 AlDS cases qualify for emergency federal funding. Although this fund was authorized to receive $\$ 875$ million in 1991 , it received only approximately $\$ 275$ million. See Rebecca Kolberg, More Emergency Funds Sought for AIDS, UPI, June 2, 1992, available in LEXIS, Nexis Library, UPI file. The National Commission on AIDS has recommended that the 1994 federal budget for AIDS research be expanded by 19.4\%. See Jacqueline Frank, AIDS Commission Blasts Bush On Lack of AIDS Plan, The Reuter Library Report, June 25, 1992, available in LEXIS, Nexis Library, Reuter file.

77. See English, supra note 71, at 1512-13 ("[T]he child welfare system must 
In addition, medical decisions regarding the treatment of infants infected with HIV are likely to be influenced by the negative attitudes of a significant number of physicians towards persons with AIDS. This negative attitude manifests itself in part by a desire to avoid personally caring for AIDS patients. For example, in a survey of a random sample of office-based primary care physicians in Los Angeles County, 48\% of physicians in the sample had elected not to care for, or said they would not provide care for, patients with HIV infection. ${ }^{78}$ Another survey suggests that this reluctance to care for adult patients with HIV flows from a combination of factors, including negative attitudes towards homosexuals and IV drug users, fear of contagion, and the time demands imposed by caring for an HIV patient. ${ }^{79}$ It is not yet clear to what extent this negative attitude extends to HIV-infected infants, but at least some of the factors identified will be present in infant care. This negative attitude may also be displayed by a reluctance to allocate scarce medical resources to individual AIDS patients. ${ }^{80}$

Finally, racial or ethnic bias may also play a role. Mirroring the increasing percentage of all AIDS cases that are found among persons

respond to the complex issues associated with perinatal drug exposure and pediatric and adolescent HIV infection at a time when their resources are already stretched thin by limited funding and increasing numbers of abused and neglected children."); Hutton \& Wissow, supra note 63 , at II4.

78. See Charles E. Lewis \& Kathleen Montgomery, Primary Care Physicians' Refusal to Care for Patients Infected with the Human Immunodeficiency Virus, $156 \mathrm{~W}$. Med. 36 (1992). See also Molly Cooke \& Merle A. Sande, Sounding Board: The HIV Epidemic and Training in Internal Medicine, 321 New Eng. J. Med. 1334, 1334 (1989).

In a study of interns and residents in New York City, 36\% of medical house officers and $19 \%$ of pediatric house officers responded that their experience with AIDS patients had led them to plan a career path less likely to involve the care of AIDS patients, and one quarter of the respondents said they would not continue to care for AIDS patients if given a choice. See Robert J. Blendon \& Karen Donelan, AIDS and Discrimination: Public and Professional Perspectives, in AIDS and the Health Care System 77, 82-83 (Lawrence O. Gostin ed., 1990) (citing R.N. Link et al., Concerns of Medical and Pediatric House Officers about Acquiring AIDS from their Patients, 78 Am. J. Pub. Health 455 (1988)).

The unwillingness to treat patients infected with HIV is inconsistent with the American Medical Association's position which recognizes the moral obligation of physicians to care for persons with HIV. See The Duty to "Attend upon the Sick" (Editorial), 266 JAMA I876 (1991); see generally Josephine Gittler \& Sharon Rennert, HIV Infection Among Women and Children and Antidiscrimination Laws: An Overview, 77 Iowa L. Rev. 1313, 1362-64 (1992) (describing response of medical community to needs of HIV patients).

79. See Barbara Gerbert et al., Primary Care Physicians and AIDS: Attitudinal and Structural Barriers to Care, 266 JAMA 2837, 2838 (1991).

80. See Children and HIV Hearing, supra note 49, at 59 (testimony of Mary Boland, R.N.) ("There are many-unfortunately-health care providers who think that because you have AIDS you should be written off and why should you want to be involved? Why should you have a right to treatment? It's just AIDS. You're going to die anyway."); see also Michael R. Flick, The Due Process of Dying, 79 Cal. L. Rev. 112 l, 1159 (1991) ("One argnment for disconnecting Mr. B from his ventilator that arose even before he was attached to it was that AIDS rendered all treatment futile."). 
of color, ${ }^{81}$ perinatally acquired pediatric AIDS has evolved as a threat primarily to children in minority groups. Of the perinatally infected children in the United States, $84 \%$ are either African-American or Hispanic. ${ }^{82}$ By contrast, African-American and Hispanic children together

81. Of the first 100,000 cases of AlDS reported in the U.S., $27 \%$ were in AfricanAmericans and $15 \%$ were in Hispanics. Of the second 100,000 cases, $31 \%$ were in African-Americans and $17 \%$ were in Hispanics. See CDC, The Second 100,000 Cases, supra note 44 , at 788 . The concentration is even greater when only AlDS cases reported in women are considered. See CDC, Update 1981-1990, supra note 56, at 3226 (finding that $51.9 \%$ of all AIDS cases in women were in African-Americans and 21.9\% were in Hispanics). The accuracy of the CDC estimates, however, is not beyond question. Because the CDC receives its data primarily from state departments of public health, who in turn receive their data from hospitals, public health clinics, and private providers, the CDC estimates may fail to reflect the full extent of HIV infection among white women. See Banks, supra note 48 , at $354 \&$ n.13 (discussing debate in medical literature over the accuracy of CDC estimates).

The heavy concentration of AIDS cases in women in these groups has added another dimension to policy discussions regarding HIV screening of women of childbearing age as a method of preventing perinatal transmission of HIV. See id. at 351-54; cf. Oleske, AIDS in Our Children, supra note 4, at 442 ("Simplistic approaches of recommending avoidance of pregnancy do not take into consideration cultural-social pressures for such women to bear children as an expression of self-worth."); Michael T. Osterholm \& Kristine L. MacDonald, Facing the Complex Issues of Pediatric AIDS: A Public Health Perspective, 258 JAMA 2736, 2736 (I987) (arguing that, in light of the disproportionate level of infection in the African-American and Hispanic communities, the control of HIV infection in the pediatric population raises "many difficult issues that touch the core of the social fabric among America's urban poor").

As Professor Banks, who considers the history of sterilization abuse and racist medical experimentation in the United States, states: "Given the racial composition of women currently thought to be at risk, HIV screening and counseling proposals designed to somehow prevent perinatal transmission have genocidal overtones." Banks, supra note 48 , at 354 . In addition, in the urban ghettoes where the vast majority of vertically acquired cases of HIV infection are found, community and religious leaders have raised charges of genocide in response to calls for infected women voluntarily to postpone or forgo pregnancy. See Ronald Bayer, Perinatal Transmission of HIV Infection: The Ethics of Prevention, in AIDS and the Health Care System, supra note 78 , at 62, 70; see also infra note 84 with respect to the legacy of mistrust left among African-Americans by the Tuskegee syphilis study.

82. See Modlin \& Saah, supra note 33, at 31. According to the CDC's 1990 figures, $77.5 \%$ of all children with AIDS in the United States are either African-American or Hispanic. See Heagarty \& Abrams, supra note 32, at 888.

Geographic concentration also characterizes the pediatric AIDS population. As of $1990,84 \%$ of pediatric AlDS cases in the United States occurred in metropolitan areas of over half a million people, with New York City, Newark, Miami, Los Angeles, and San Juan accounting for $45 \%$ of these cases. See Mendez \& Jule, supra note 52, at 637. Newark alone is home to $20 \%$ of all HIV-infected children in the United States. See AlAA Hearings, supra note 67 , at 1,3-4. The figures are similarly distressing for New York City: the Bronx has $10 \%$ of all pediatric AlDS cases in the United States, see AIAA Hearings, supra note 67 , at 3-4, and as long ago as 1987 , one in sixty-three newborns in the Bronx were found to be seropositive. See Children and HIV Hearing, supra note 49 , at 50 (testimony of Dr. Joanne E. Lukomnik). The current geographic concentration of HIV-infected children, however, does not suggest that other areas will escape having to face issues regarding the care of children with HIV infection; it simply means the crisis is temporarily confined. As of 1990 , eighty of ninety-three metropolitan areas had 
comprise only $10 \%$ of the general pediatric population. ${ }^{83}$ Evidence of continuing racial bias in medicine suggests that decisions regarding the medical care of more than three quarters of HIV-infected infants may be subject to further negative influence. ${ }^{84}$

Taking all the foregoing factors together, a disturbing picture emerges of the medical and social contexts in which medical treatment decisions for the growing number of infants infected with HIV are likely to be made. First, because of coincident health risks suffered by many of these infants, they run a relatively high chance of suffering potentially life-threatening complications in the neonatal period. Second, many of these infants will have their medical treatment decisions made for them by the state rather than by their parents. Third, because these infants are HIV infected and are likely to be either African-American or Latino, they may trigger biases on the part of those involved in their medical care. Perinatally infected children have been called the "ultimate minority," 85 and they are a minority that cannot effectively advocate for themselves. More to the point, they are a minority that cannot even begin to make decisions for themselves, and in many instances medical decision-making power will be vested in the hands of decisionmakers who may be motivated by concerns and biases inconsistent with the best interests of the HIV-infected infants needing medical treatment. Thus, while vulnerability may not in itself justify legal protection, the extreme vulnerability of perinatally infected infants to selective nontreatment should justify our close scrutiny of existing law

reported at least one case of pediatric AIDS. See Mendez \& Jule, supra note 52, at 637-38. See also Hutton \& Wissow, supra note 63, at 106 (noting that in inner city Baltimore, approximately one in eighty infants is born to a seropositive mother); Osterholm \& MacDonald, supra note 81, at 2737 (citing Minneapolis as example of city where the disproportionate racial and ethnic concentration of pediatric AIDS cases is being replicated).

83. See McMillen \& Groze, supra note 67 , at 60.

84. The most notorious example of racism in American medical science is the Tuskegee syphilis study, which studied the natural course of untreated syphilis by following approximately 400 poor black men infected with syphilis without providing treatment to them, even when penicillin was developed as an effective treatment for syphilis in the 1940s. The study began in 1932 and continued until 1972, when it was publicly exposed. For a full account of the Tuskegee study, see James H. Jones, Bad Blood: The Tuskegee Syphilis Experiment (1981). Although blatant examples of racism in medicine may be less common today, several studies continue to suggest that a more subtle form of racism continues. See Banks, supra note 48 , at 359,360 n.35 (citing studies in the medical literature providing evidence of continuing racial bias in medicine). Cf. Gittler \& Rennert, supra note 78, at 1331 n.87 ("The continuing widespread stigmatization of people of color creates enormous difficulties for effectively combatting the HIV/AIDS epidemic.' ") (quoting National Comm'n on AlDS, The Challenge of HIV/AIDS in Communities of Color 2-3 (1992)); James H. Jones, The Tuskegee Legacy: AIDS and the Black Community, Hastings Center Rep., Nov.-Dec. I992, at 38 (suggesting that the Tuskegee study's legacy of suspicion and distrust has hampered efforts to control AIDS in the black community).

85. Children and HIV Hearing, supra note 49, at 31 . 
to determine whether it provides any protection. That scrutiny seems especially imperative in light of the state's role in providing foster care and making medical decisions for a significant number of infected infants.

\section{The Legal Legacy of Baby Doe}

Although controversy over the selective nontreatment of handicapped newborns was brewing in the $1970 \mathrm{~s},{ }^{86}$ the death of Baby Doe in April 1982 catapulted the debate to national prominence. When Baby Doe was born on April 9 in Bloomington, Indiana, he was diagnosed with Down syndrome and an obstruction of the esophagns that precluded normal feeding but was surgically correctable; on the advice of their obstetrician, Baby Doe's parents refused to consent to surgery to correct that obstruction. ${ }^{87}$ The hospital sought a judicial hearing to override the parents' decision, but neither the Indiana Superior Court nor the local Child Protection Committee found any reason to interfere with the parents' decision. ${ }^{88}$ Baby Doe died when he was six days

86. Several articles published in medical journals in the 1970 s displayed the interest of some pediatricians in establishing criteria for nontreatment of infants born with congenital anomalies and the willingness of practitioners to acquiesce in parental decisions not to treat such infants. See, e.g., Raymond S. Duff \& A.G.M. Campbell, Moral and Ethical Dilemmas in the Special-Care Nursery, 289 New Eng. J. Med. 890, 891 (1973) (reporting that over a two and a half year period, 43 of 299 deaths in the special care nursery of Yale-New Haven Hospital resulted from the withdrawal of treatment); John Lorber, Early Results of Selective Treatment of Spina Bifida Cystica, 4 Brit. Med. J. 201, 203 (1973) (examining list of contraindications to acute therapy for infants with spina bifida cystica); Shaw et al., supra note 20, at 588 (reporting results of survey concerning treatment decisions for infants born with congenital abnormalities). See generally Koop, supra note 2 (describing the medical debate over nontreatment in the 1970s); Stanley J. Reiser, Survival at What Cost? Origins and Effects of the Modern Controversy on Treating Severely Handicapped Newborns, $11 \mathrm{~J}$. Health Pol. Pol'y \& L. 199 (1986) (describing technological innovations, emergence of bioethics movement, growth of government involvement in health care, and social and medical debate on abortion as background for controversy over selective nontreatment).

87. See Koop, supra note 2, at 109.

88. See Bowen v. American Hosp. Ass'n, 476 U.S. 610, 617 (1986) (plurality opinion). The trial judge reasoned that because the parents were faced with two competent medical opinions regarding the appropriateness of corrective surgery, they could choose to follow either opinion without government interference. See Lawrence D. Brown, Givil Rights and Regulatory Wrongs: The Reagan Administration and the Medical Treatment of Handicapped lnfants, 11 J. Health Pol. Pol'y \& L. 231, 233 (1986).

Additional attempts to obtain judicial intervention were to no avail: the lndiana Court of Appeals denied a request for an immediate hearing, In re Infant Doe, No. GU 8204-004A (Monroe County Cir. Ct. Apr. 12, 1982), and the Indiana Supreme Court rejected a petition for a writ of mandamus, State ex rel. Infant Doe v. Baker, No. 482-S140 (lnd. 1982). Baby Doe died while a stay was being sought in the United States Supreme Court, which subsequently denied certiorari in the case. See Infant Doe v. Bloomington Hosp., 464 U.S. 961 (1983). See also Bowen, 476 U.S. at 617 n.5. 
old. ${ }^{89}$ The stark facts of this six-day-long drama set in motion a chain of legal events that would take four years to play out, ${ }^{90}$ but would resolve little. Instead, the federal responses to Baby Doe, as discussed below, ultimately have failed to resolve the confusion surrounding the legal status of selective nontreatment. ${ }^{91}$

\section{A. Baby Doe as a Handicap Discrimination Problem}

Just weeks after Baby Doe's death, acting on a directive from President Reagan, ${ }^{92}$ the Office of Civil Rights of the Department of Health and Human Services sent a notice to most of the nation's hospitals "remind[ing]" them that the Rehabilitation Act of 1973 prohibited a recipient of federal financial assistance from withholding from a handicapped infant nutrition or medical treatment necessary to correct a life-threatening condition. ${ }^{93}$ The statutory authority cited, section 504 of the Rehabilitation Act, provided: "No otherwise qualified handicapped individual ... shall, solely by reason of his handicap, be excluded from the participation in, be denied the benefits of, or be

89. For a fuller account of the turmoil of Baby Doe's brief life, see Koop, supra note 2 , at $109-10$.

90. I do not mean to suggest that the legal issues raised by the Baby Doe case were fully resolved by 1986 . Nonetheless, since the Supreme Court's decision in Bowen, the law regarding nontreatment of disabled infants has been relatively static, if not uncontroversial.

91. See, e.g., Robert H. Mnookin, Two Puzzles, 1984 Ariz. St. L.J. 667, 668. Professor Mnookin noted the "striking dichotomy between the law on the books .... and the law in action" with respect to parental withholding of life-sustaining treatment for disabled newborns. He supported his observation by comparing a formalistic approach to the legality of nontreatment, as exemplified in John A. Robertson, Involuntary Euthanasia of Defective Newborns: A Legal Analysis, 27 Stan. L. Rev. 213 (1975), which finds selective nontreatment to be outlawed, with a legal realist's approach, which finds no criminal prosecutions and few neglect proceedings triggered by parental nontreatment. Mnookin therefore concluded that parents have a legal right to select nontreatment. See Mnookin, supra, at 668-7I. Cf. Carl E. Schneider, supra note 2, at 152 (noting "a troubling disjunction between the law on the books, which seems to make neonatal euthanasia criminal, and the law in action, which does not punish it").

92. See Brown, supra note 88, at 233-35 (describing President Reagan's reaction to Baby Doe's death). The Reagan administration's conviction that federal law should prohibit the withholding of medical treatment from handicapped infants was closely linked to the administration's opposition to abortion. See Koop, supra note 2, at 101 ("The death of handicapped newborn infants ... is extraordinarily important to those of us who are interested in the sanctity of human life because this practice could never have come about had it not been for abortion."); Constance Paige \&. Elisa B. Karnofsky, The Antiabortion Movement and Baby Jane Doe, $11 \mathrm{~J}$. Health Pol. Pol'y \& L. 255, 258 (1986). One commentator in 1985 linked the fervor with which right to life groups pursued the issue to their inability in the 1970 s to prevail on the abortion front. See John D. Arras, Ethical Principles for the Care of Imperiled Newborns: Toward an Ethic of Ambiguity, in Which Babies Shall Live?, supra note 2, at 83, 83. Following this reasoning, the inroads made on abortion rights since the late $1980 \mathrm{~s}$ may explain in part why right to life groups have recently paid little attention to newborn nontreatment issues.

93. 47 Fed. Reg. 26027 (1982). 
subjected to discrimination under any program or activity receiving Federal financial assistance."94 The Department followed up on this notice in March 1983 with the promulgation of an "Interim Final Rule," requiring hospitals to post in a conspicuous place a notice titled: "DISCRIMINATORY FAILURE TO FEED AND CARE FOR HANDICAPPED INFANTS IN THIS FACILITY IS PROHIBITED BY FEDERAL LAW."95

The Interim Final Rule was promptly challenged by a group of medical organizations and struck down by the D.C. District Court in April 1983 on the grounds that it was "arbitrary and capricious and promulgated in violation of the Administrative Procedure Act."96 Undeterred by this setback, the Department recommenced the rulemaking process and promulgated Final Rules by the beginning of $1984 .{ }^{97}$ For the most part, the new set of rules varied only slightly from the invalidated Interim Final Rule. ${ }^{98}$ ln a substantial departure, however, the Final Rules required state child protective services agencies that received federal funds to use their "full authority pursuant to state law to prevent instances of unlawful medical neglect of handicapped infants."99 Like the Interim Final Rule, the Department's Final Rules

94. 29 U.S.C. $§ 794$ (1988). In enacting the Rehabilitation Act in 1973, Congress's purpose was to develop and support programs for vocational rehabilitation and independent living for persons with handicaps. See infra note 238. The civil rights provision of the Act, $\S 504$, drew scant legislative attention and was included in the legislation by congressional staffers who were concerned that the vocational rehabilitation programs' goal of allowing disabled persons to enter the mainstream of society might be impeded by discriminatory attitudes of employers. See Richard K. Scotch, From Good Will to Civil Rights: Transforming Federal Disability Policy 51 (I984).

95. 48 Fed. Reg. 9630, 9631-32 (1983). The Interim Final Rule also required the notice to advise of the availability of a confidential "hotline" for reporting violations and authorized expedited investigations and access to medical records when HHS officials believed such access was necessary to protect a handicapped infant. Although these provisions were decried by medical personnel as being disruptive of hospital routine and infant care, see American Academy of Pediatrics v. Heckler, 561 F. Supp. 395, 399 (D.D.C. 1983), they were consistent with "fundamental standard operating procedures" for enforcing federal civil rights laws. See Brown, supra note 88, at 235-36 (describing the drafting of the Interim Final Rule).

96. American Academy of Pediatrics, $561 \mathrm{~F}$. Supp. at 404. The court found the Interim Final Rule arbitrary and capricious because HHS failed to consider important aspects of medical decision-making and found an additional violation of the Administrative Procedure Act (APA) in the Secretary's failure to solicit public comment before issuing the rule. See id. at 399-401.

97. See 45 C.F.R. § 84.55(b)(3) (1983) (codification of Final Rules).

98. The Final Rules required hospitals to post informational notices on one of two approved forms and authorized expedited access to records and expedited compliance actions. See 45 C.F.R. \& 84.55 (b), (d), (e).

99. 45 C.F.R. \& 84.55(c)(1). As part of this mandate, the Final Rules set forth certain procedures that the state agencies would be required to establish and maintain for receiving and reviewing reports of medical neglect. See 45 C.F.R. $\S 84.55(c)(1)(\mathrm{i})-(\mathrm{v})$. 
were promptly challenged in court by a group of medical organizations. The fate of the challenge to the Final Rules, however, was shaped by a decision of the Second Circuit Court of Appeals arising out of another highly publicized instance of nontreatment. ${ }^{100}$

At issue in that case, United States $v$. University Hospital, ${ }^{101}$ was the Department of Health and Human Services' authority pursuant to section 504 to obtain from a hospital the medical records of an infant whose parents had refused to consent to corrective surgery for spina bifida. ${ }^{102}$ The court framed the question as one of statutory construction: Did Congress intend section 504 to reach medical treatment decisions for infants with handicaps? ${ }^{103}$ After reviewing the regulatory history of section 504 and parsing the statutory language, the court concluded that the statute could not sensibly be applied to such decisions. Although the infant might be a "handicapped individual" under section 504, its very handicap was likely to give rise to the need for medical services, ${ }^{104}$ and the infant therefore could not be "otherwise qualified" for those services, as required by section 504's express language. Likewise, the court rejected the idea that a medical treatment decision could be found to be discriminatory " $[w]$ here the handicap-

100. See United States v. University Hosp., 729 F.2d 144 (2d Cir. 1984). This decision was one of several dealing with issues raised by the nontreatment of an infant, known as "Baby Jane Doe," born with multiple congenital defects, including myelomeningocele (spina bifida or imperfect closure of the spinal column), microcephaly (an abnormally small head), and hydrocephalus (fluid in the cranial vault). Baby Jane Doe's parents declined to consent to corrective surgery for the spina bifida and hydrocephalus, choosing instead to follow a "conservative" course of medical treatment, involving good nutrition, administration of antibiotics, and measures to prevent infection. See id. at 146. Litigation challenging the parents' choice in the New York State courts ultimately failed because the petitioner seeking an order directing University Hospital to perform the corrective surgery had no interest in or relationship to the family and had not requested the aid of the responsible state agency. See Weber v. Stony Brook Hosp., 456 N.E.2d 1186, 1187-88 (N.Y. 1983) (per curiam). The matter found its way into federal court when, during the course of the state court proceedings, HHS received a complaint that Baby Jane Doe was being discriminatorily denied treatment in violation of $\S 504$. When HHS's request to the hospital for access to all of Baby Jane Doe's medical records was denied, the federal government brought suit alleging that University Hospital had violated § 504 and 45 C.F.R. $\$ 80.6$ (c) (an access provision in the general regulations promulgated under § 504). See Universily Hosp., 729 F.2d at $147-48$.

For a follow-up story on Baby Jane Doe's life after the litigation, see Glazer, supra note 18 , at 8 .

101. 729 F.2d 144 (2d Cir. 1984).

102. Because this litigation commenced after the Department's Interim Final Rule had been held invalid, but before its Final Rules were promulgated, at issue in Universily Hospital was the Department's authority under $\$ 504$ itself and an implementing regulation that predated the Baby Doe case, 45 C.F.R. $\S 80.6$ (c) (1982), as incorporated by 45 C.F.R. $\S 84.61$ (1982). See Universily Hosp., 729 F.2d at 146.

103. See 729 F.2d at 150.

104. See id. at $155-57$. 
ping condition is related to the condition(s) to he treated."105 Thus, the court refused to sanction HHS's attempt to conduct an investigation of alleged nontreatment pursuant to section 504. ${ }^{106}$

Judge Winter dissented from the majority's conclusion, largely in reliance on Congress' treatment of handicap discrimination as analogous to race discrimination. ${ }^{107}$ Once that analogy is drawn, according to Judge Winter, the analytical task of applying the law to medical treatment decisions hecomes more straightforward: "A judgment not to perform certain surgery because a person is black is not a bona fide medical judgment. So too, a decision not to correct a life threatening digestive problem because an infant has Down's Syndrome is not a bona fide medical judgment." 108 Thus, Judge Winter concluded that section 504 applies to the provision of medical services to handicapped infants.

University Hospital's holding that Congress did not intend section 504 to apply to medical treatment decisions for handicapped infants provided clear authority to the district court hearing the challenge to HHS's Final Rules to declare the Rules invalid, a decision the Second Circuit summarily affirmed in accordance with its own earlier decision. ${ }^{109}$ The Supreme Court granted certiorari in Bowen v. American Hospital Association 110 and affirmed, but on narrower grounds.

The plurality opinion ${ }^{111}$ in Bowen limited its consideration to the validity of the Final Rules' "four mandatory components"112 and dis-

105. Id. at I57.

106. See id. at 161. In so doing, the Court of Appeals affirmed the judgment of the district court without confirming its reasoning. In granting summary judgment for the hospital, the district court reasoned that the hospital's failure to perform the corrective surgery could not be a violation of $\S 504$ because it was based on Baby Jane Doe's parents' refusal to consent to the surgery, not on the infant's handicap. See United States v. University Hosp., 575 F. Supp. 607, 614 (E.D.N.Y. 1983), aff'd, 729 F.2d 144 (2d Cir. 1984).

107. See University Hosp., 729 F.2d at 162 (Winter, J., dissenting). In finding this analogy, Judge Winter cited to the Senate Report on $\$ 504$, which stated: "Section 504 was patterned after, and is almost identical to, the antidiscrimination language of section 601 of the Civil Rights Act of 1964 ...." Id. (citing S. Rep. No. 1297, 93d Cong., 2d Sess. 18 (1974), reprinted in 1974 U.S.C.C.A.N. 6373, 6390).

108. Id. Judge Winter, however, failed to apply his reasoning to the judgment not to perform surgery to correct the myelomeningocele suffered by Baby Jane Doe and thus failed to confront the question of how to apply antidiscrimination law when the disabling condition is the very one needing treatment. For a discussion of the difficulty of applying antidiscrimination law to such a situation, see infra text accompanying notes 253-254.

109. See American Hosp. Ass'n v. Heckler, 585 F. Supp. 541, 542 (S.D.N.Y.), aff'd, 794 F.2d 676 (2d Cir. 1984).

110. 476 U.S. 610 (1986).

111. Justices Marshall, Blackmun, and Powell joined in the opinion authored by Justice Stevens. Chief Justice Burger concurred in the judgment. Justices White, Brennan, and O'Connor dissented. Justice Rehnquist took no part in the decision. See id. at 611 .

112. 1d. at 624 . The four mandatory provisions required (1) that health care providers receiving federal funds post certain notices; (2) that state child protective 
claimed any need to determine "whether $\S 504$ ever applies to individual medical treatment decisions involving handicapped infants."113 Leaving this fundamental issue unaddressed, the Court focused on whether the Department had sufficiently justified its promulgation, pursuant to section 504, of rules authorizing the federal government to intervene in medical treatment decisions for handicapped infants. ${ }^{114}$

The Secretary of HHS justified the need for federal intervention by pointing out that hospitals could be violating section 504 in one of two ways: either by failing to treat a handicapped infant when its parents have consented to treatment ${ }^{115}$ or by failing to report incidents of medical neglect of handicapped infants to state child protection agencies. ${ }^{116}$ The plurality found insufficient evidence in the administrative record to support either justification. ${ }^{117}$ Accordingly, the plurality invalidated the four mandatory provisions of the Final Rules for lack of a proper evidentiary foundation. ${ }^{118}$

In dissent, Justice White found that the appeal directly posed the question whether section 504 authorized the Secretary to regulate med-

services agencies establish certain procedures; (3) immediate access to patient records; and (4) expedited compliance actions. See id. at 613-16 (citing 45 C.F.R. $\$ 84.55$ (1985)).

I13. Id. at 624 .

114. Before assessing the Secretary's justifications for intervention, the plurality emphasized that prior to the regulatory activity triggered by the Baby Doe case, the federal government played no role in the process of medical decision-making for infants. See id. at 627-28.

115. The Department's first attempts at rulemaking following the Baby Doe case sought to prescribe hospitals' obligations under $\$ 504$ without addressing the absence of parental consent to treatment as an issue. See id. at 617-19. In promulgating the Final Rules, however, the Secretary recognized that $\$ 504$ does not mandate that a hospital may override a discriminatory parental decision. See 49 Fed. Reg. 1631 (1984) (preamble to Final Rules).

116. See 476 U.S. at 637.

117. The plurality found no evidence that hospitals refused treatment authorized by an infant's parents. See id. at 631 . Instead, the instances cited by the Secretary as support for the regulations involved parental refusal to consent to treatment. See id. at 631-32. No $\$ 504$ violation is involved in such cases, however, because "without the consent of the parents or a surrogate decisionmaker the infant is neither "otherwise qualified' for treatment nor has he been denied care 'solely by reason of his handicap." " Id. at 630 .

In response to the Secretary's other asserted justification, the plurality conceded that a hospital's selective failure to report medical neglect of handicapped infants when it would report neglect of a similarly situated infant could violate $\$ 504$, but again found no specific evidence that such a violation had occurred. See id. at 637-38. Moreover, the plurality reasoned that the Final Rules did not directly require hospitals to report instances of medical neglect of handicapped infants, but instead imposed an obligation on state agencies to require such reports, an imposition the plurality found "totally foreign" to the Secretary's authority to prevent discrimination under $\S 504$. See id. at 639-40.

118. See id. at 643 . The lack of an evidentiary basis for the Final Rules particularly concerned the plurality in light of the unprecedented federal intrusion into an area of traditional state governance that enforcement would entail. See id. at 643-44. 
ical treatment decisions for handicapped newborns. ${ }^{119}$ Addressing that issue, the dissent disagreed with the Second Circuit's conclusion in University Hospital and found that in some situations section 504 may apply to medical treatment decisions for newborns. For example, the dissent suggested that in cases involving medical treatment for a problem completely unrelated to an infant's handicapping condition, the failure to provide treatment that an otherwise healthy child would receive could constitute discrimination on the basis of handicap. ${ }^{120}$ In addition, in response to the plurality's conclusion that no need for the Final Rules had been shown, the dissent argued that a "more elusive discrimination" justifying federal regulation could be found in physicians' influence on parental decisions regarding consent to treatment for handicapped newborns. ${ }^{121}$

Thus, the four years of legal wrangling following Baby Doe's death came to an end when the Supreme Court pulled the rug out from under efforts ${ }^{122}$ by the Reagan administration to use handicap discrimination law to save the lives of handicapped infants denied life-saving treatment. ${ }^{123}$ The legal battles that flowed from the Administration's reliance on section 504 illustrate some of the difficulties inherent in adopting a disability discrimination approach to the problem of selective nontreatment. Although the Administration's instinct that treating some infants differently based simply on their handicapped status was unjust and contrary to the spirit of the nondiscrimination provision of the Rehabilitation Act was sound, the government's response failed to address adequately the implication of section 504's "otherwise qualified" standard. The series of regulations issued under section 504 raised but did not answer the question of what it means for a handicapped infant like the infant in University Hospital to be "otherwise qualified" for medical treatment that would not be called for in the absence of her handicap.

The Supreme Court did not respond to this difficulty directly, for

119. See id. at 648 (White, J., dissenting).

120. See id. at 655-56 (White, J., dissenting).

121. See id. at 658-59 (White, J., dissenting). The plurality rejected this theory of justification as "find[ing] no support in the text of the regulation, the reasoning of the Secretary, or the briefs filed on his behalf in this Court." Id. at 636 n.22.

122. Bowen left in force the nonmandatory provisions of the Final Rules recommending that health care providers establish Infant Care Review Committees (ICRCs) and describing a model ICRC. The purpose of the ICRCs was to assist in the development of treatment standards for handicapped infants and to provide assistance in making individual treatment decisions. See 45 C.F.R. $\$ 84.55$ (a), (f) (1992).

I23. Justice Stevens' plurality opinion chastised the Secretary of HHS: "[N]othing in the statute authorizes the Secretary to dispense with the law's focus on discrimination and instead to employ federal resources to save the lives of handicapped newborns, without regard to whether they are victims of discrimination by recipients of federal funds or not." 476 U.S. at 647 . What the plurality opinion failed to address, and what this Article seeks to clarify, is what the concept of discrimination means in the context of medical treatment decision-making. 
their decision in Bowen invalidated the section 504 regulations based on the Secretary's procedural failure to develop a record justifying the regulations, but conspicuously left open the question whether medical treatment decisions for those infants could ever fall within the scope of section 504's protection. Moreover, although the Second Circuit concluded in University Hospital that medical treatment decisions for a disabled infant were beyond the scope of section 504, its reasoning reflected the facts of the case before it, where the infant's disability itself gave rise to the need for medical treatment. ${ }^{124}$ Thus, neither Bowen nor University Hospital needs be read to preclude application of section 504 to selective nontreatment when, for example, the parents of a disabled infant do not refuse to consent to the treatment and the condition requiring treatment is unrelated to the infant's disabling condition. Thus, the question of whether and how disability discrimination law ${ }^{125}$ can be appropriately applied to medical treatment decision-making remains open. By the time the Supreme Court rendered its decision in Bowen, however, the federal government was already using a new mechanism for combatting selective nontreatment: in 1984 Congress amended the Child Abuse Prevention and Treatment Act ${ }^{126}$ to include provisions addressed to nontreatment of infants.

\section{B. Baby Doe as a Child Welfare Problem}

In enacting the Child Abuse Amendments of 1984 (the Amendments or CAA), ${ }^{127}$ Congress cast the issue of selective nontreatment as a child welfare issue properly within tbe authority of state cbild welfare agencies. Rather than protecting disabled infants from discrimination, the Amendments sought to protect them from medical neglect, which Congress defined as including "instances of withholding of medically indicated treatment from disabled infants witb life-threatening conditions." 128 This phrase, moreover, is defined as meaning "the failure to respond to the infant's life-threatening conditions by providing treatment (including appropriate nutrition, hydration, and medication) which, in the treating physician's or physicians' reasonable medical judgment, will be most likely to be effective in ameliorating or cor-

124. See United States v. University Hosp., 729 F.2d 144, 155-57 (2d Cir. 1984); see also supra text accompanying notes 101-106.

125. Although this Article focuses its analysis on how the ADA should be interpreted to apply in the context of medical treatment decision-making, this analysis is also largely applicable to interpreting $\S 504$ in that context. While either disability discrimination law may thus be applicable, infra Part VI.A discusses why the ADA may provide a better vehicle for addressing disability discrimination in medical decisionmaking.

126. 42 U.S.C. \$§ 5101-5106 (1988).

127. Pub. L. No. 98-457, 98 Stat. 1749 (codified as amended at 42 U.S.C. § 5101-5106 (1988)).

128. 42 U.S.C. $\$ 5106 \mathrm{a}(\mathrm{b})(10)(1988)$. 
recting all such conditions." 129 Backing away from an absolute treatment mandate, however, Congress limited the broad sweep of the statutory definition of medical neglect by making exceptions for a failure to provide treatment

when, in the treating physician's or physicians' reasonable medical judgment- $(\AA)$ the infant is chronically and irreversibly comatose; (B) the provision of such treatment would-(i) merely prolong dying; (ii) not be effective in ameliorating or correcting all of the infant's life-threatening conditions; or (iii) otherwise be futile in terms of the survival of the infant; or (C) the provision of such treatment would be virtually futile in terms of the survival of the infant and the treatment itself under such circumstances would be inhumane. ${ }^{130}$

The regulations issued by HHS under the Child Abuse Amendments and the interpretative guidelines published as an Appendix to the regulations provide an administrative gloss on the meaning of the statutory standards. ${ }^{131}$ The Appendix indicates that HHS expects to construe narrowly the three exceptional situations when failure to treat will not constitute medical neglect; ${ }^{132}$ in particular, the Appendix lets it be understood that quality of life considerations must not be the basis of a decision not to treat a disabled infant. ${ }^{133}$

Despite the Department's attempt to provide interpretative guidance, much disagreement remains about just how far the Amendments and regulations go in requiring continued treatment of severely ill or disabled infants. ${ }^{134}$ For those who focus on the statutory exceptions'

129. 42 U.S.C. $\S 5106 \mathrm{~g}(10)$.

130. 1 d.

131. See 45 C.F.R. $\S \S 1340.15,1340$ app. (1992). The Appendix includes interpretations that were contained in the Department's proposed rule, 49 Fed. Reg. 48,160 (1984) (proposed Dec. 10, 1984), but withdrawn by the Department following objections by commentators. In publishing the Appendix, the Department disavowed any attempt to establish the interpretations as binding rules of law. "Rather," the Appendix states, "this guidance is intended to assist in interpreting the statutory definition so that it may be rationally and thoughtfully applied in specific contexts in a manner fully consistent with the legislative intent." 45 C.F.R. $\$ 1340$ app., at 297.

132. See, e.g., 45 C.F.R. $\$ 1340$ app., at 300-01 (stating that the "merely prolong dying" provision does not apply "where the prognosis is not for death in the near future, but rather the more distant future"); id. at 302 (interpreting "virtually futile" to mean that "the treatment is highly unlikely to prevent death in the near future").

133. See id. at 298 (stating that the definition "does not sanction decisions based on subjective opinions about the future 'quality of life' of a retarded or disabled person"); id. at 303 (stating that HHS "strongly believes" an interpretation of the inhumaneness exception that would allow consideration of the infant's future "quality of life" is inconsistent with the statute).

134. The two, and apparently only, instances in which courts have applied the standards of the CAA to treatment decisions for individual infants shed little light on the scope of the standards. In In re Steinhaus, No. J-86-92 (Minn. Redwood County Ct., Juv. Div. Sept. 11, 1986), reprinted in Order in the Steinhaus Case, 2 Issues L. \& Med. 241,251 (1986), the court had to decide whether antibiotics and resuscitation could be withheld from an infant suffering from severe brain damage as a result of an abusive 
strict language, the requirements seem overbroad and harsh: "A slim chance of survival apparently justifies inhumane treatment as does some chance of a survival wracked by excruciating pain, severe abnormalities and a torturous regime of medical interventions."185 By contrast, for those who focus on the directive that decisions reflect "reasonable medical judgment,"136 the regulations appear to leave some latitude in decision-making. ${ }^{137}$ And despite the Appendix's firm stance that quality of life judgments are off limits, Professor Nancy Rhoden argues that, to the extent the three exceptions allow some degree of discretion, they embody "an implicit recognition of the relevance of quality of life concerns." 138

State child protective service agencies, rather than HHS, are re-

beating. The court's holding turned on whether the infant was in a chronic and irreversible coma or a persistent vegetative state, since the CAA provides that treatment may be withheld from infants in the former condition, but not the latter. A further hearing found that the infant was chronically and irreversibly comatose and that resuscitation was not required. See In re Steinhaus, No. J-86-92 slip op. at 3 (Minn. Redwood County Ct., Juv. Div. Oct. 18, 1986).

In In re Baby Girl Muller, described in James Bopp, Jr. \& Mary Nimz, A Legal Analysis of the Child Abuse Amendments of 1984, in Compelled Compassion, supra note 2, at 73, 91-92, the court was confronted with the issue of whether ventilator support could be withdrawn from an infant born one month prematurely with severe, permanent mental and physical disabilities. The infant could neither breathe without the assistance of a ventilator nor be fed except through intravenous means. The court found that (1) the infant was terminally ill despite the aid of life-support systems; and (2) the use of the ventilator was thus merely prolonging death and was not effective in ameliorating or correcting all of the infant's life-threatening conditions. Since the CAA did not require treatment under these conditions, the court held that the ventilator could be withdrawn provided that all other medical care, including nutrition and hydration, continue. See id.

135. Newman, supra note 2, at 4; see also Loretta M. Kopelman et al., Neonatologists, Pediatricians, and the Supreme Court Criticize the "Baby Doe" Regulations, in Compelled Compassion, supra note 2, at 237, 262-65 (arguing that the regulations may be interpreted as requiring physicians to act inconsistently with the infant's best interests); Robert F. Weir, Pediatric Ethics Committees: Ethical Advisers or Legal Watchdogs? 15 L. Med. \& Health Care 99, 104 (1987) (arguing that the Amendments reflect an inflexible rule that "whenever current technology can prolong life (that is, can prolong noncomatose life beyond the 'near future'), it must be employed") (quoting J.C. Moskop \& R.L. Saldanha, The Baby Doe Rule: Still a Threat, 14 Hastings Center Rep. 10 (1984)).

136. The regulations define "reasonable medical judgment" as "medical judgment that would be made by a reasonably prudent physician, knowledgeable about the case and the treatment possibilities with respect to the medical conditions involved." 45 C.F.R. $\$ 1340.15$ (b)(3)(ii) (1992).

137. See Lantos, supra note 18 , at 445 . Physicians' confusion regarding the meaning and effect of the regulations is evidenced by the results of a survey of perinatal pediatricians. See Kopelman et al., supra note 18, at 678-79. The authors posed three hypothetical case histories and asked respondents, among other questions, what response the federal regulations would require in the hypothetical cases, and found little agreement among respondents as to what action the regulations required in specific cases. See id.

138. Rhoden, supra note 2 , at 1313 . 
sponsible for enforcing the Amendments' protections by establishing procedures for receiving and responding to reports of medical neglect. As part of their enforcement role, the Amendments call for state agencies to have authority to initiate legal proceedings "to prevent the withholding of medically indicated treatment from disabled infants with life-threatening conditions."139

In marked contrast to the flurry of regulatory and judicial activity spawned by HHS's attempts to regulate selective nontreatment under section 504, the Child Abuse Amendments of 1984 have faced no judicial challenges and have generated little litigation. ${ }^{140}$ This paucity of litigation may be partly attributable to the Amendments' genesis as a political compromise among right to life activists, disability rights groups, and the medical profession, ${ }^{141}$ or it may suggest that the Amendments, as implemented, have done little to challenge the nature of medical decision-making in the neonatal or pediatric intensive care units.

In fact, the efficacy of the Amendments in combatting nontreatment of disabled newborns is commonly questioned. Although evaluating the impact of the Child Abuse Amendments is a difficult task, ${ }^{142}$ as a practical matter the Amendments may be difficult to enforce for a combination of reasons. First, the Amendments delegate enforcement responsibility to a chronically overburdened, understaffed group: state child protective services agencies. ${ }^{143}$ The obligation to take on this new task of policing against selective nontreatment is not mandatory on the state agencies, but is only a condition of receiving federal grant

139. 42 U.S.C. $\$ 5106 \mathrm{a}(\mathrm{b})(10)(\mathrm{C})(1988)$. The requirement that the state agency have such procedures in place is not directly binding on the states, but is a condition of receiving federal grants for child abuse and neglect prevention and treatment programs. See 42 U.S.C. \$ $5106 \mathrm{a}(\mathrm{b})(10)$. 134.

140. For a description of two cases decided under the Amendments, see supra note

141. In proposing regulations under the Amendments, HHS commented that the regulations had developed through the cooperation of medical and disability advocacy organizations. See 49 Fed. Reg. 48,160 (1984) (proposed Dec. 10, 1984). Right to life groups also influenced the enactment of the legislation. See Martin H. Gerry \& Mary Nimz, The Federal Role in Protecting Babies Doe, 2 lssues L. \& Med. 339, 343 (1987).

142. See Janna C. Merrick, Conflict, Compromise, and Symbolism: The Politics of the Baby Doe Debate, in Compelled Compassion, supra note 2, at 35, 60. Merrick suggests that the following factors complicate the evaluation: the substantial disagreement about the extent of selective nontreatment prior to the federal government's initiatives; the vagueness of the Amendments' language; and the lack of adequate information regarding changes in medical practice and any causal relationship to the Amendments.

143. See 42 U.S.C. $\$ 5106 \mathrm{a}(\mathrm{b})(10)$ (1988); cf. Koop, supra note 2, at 111-12 (reasoning that the Amendments' standards, because they are left to states with different child abuse regulatory procedures and are not enforceable against individuals, effectively are unenforceable); Newman, supra note 2, at 6 (" $[T]$ he law selects the understaffed, often overwhelmed personnel of state and local child abuse agencies to carry out its mandate."). 
monies. ${ }^{144}$ Yet this carrot may not be inducement enough ${ }^{145}$ for the state agencies to rechannel scarce resources away from growing problems of physical and sexual abuse and drug-exposed infants to Baby Doe enforcement activity. Moreover, the Amendments, by their very terms, ${ }^{146}$ focus solely on whether a state has in place procedures for the purpose of responding to reports of medical neglect; they impose no obligation to implement those procedures aggressively. ${ }^{\mathbf{1 4 7}}$

The nature of the neonatal intensive care unit (N1CU), where most decisions regarding the treatment or nontreatment of disabled newborns are made, presents an additional structural barrier to strict enforcement of the federal standards. ${ }^{148}$ The process of making treatment decisions for infants in the NICU has been described as a "closedworld phenomenon," where external influences, including legal authority, are frequently denied and where neonatologists may usurp parental decision-making authority. ${ }^{149}$ In addition, the tightly knit

144. See 42 U.S.C. $\$ 5106 a(b)$ (1988).

145. In 1992, the Child Abuse and Neglect Basic State Grants distributed nationally amounted to a total of $\$ 17,518,000$. Indiana, Maryland, and Pennsylvania did not apply for Basic State Grants. Telephone conversation witb Mary McKeough, National Center for Child Abuse and Neglect (Feb. 23, 1993). Cf. Newman, supra note 2, at 6 (citing $\$ 9$ million as the total outlay for 1987).

146. 42 U.S.C. $\$ 5106 a(b)(10)$ (1988) provides:

In order for a State to qualify for a grant under subsection (a) of this section, such State shall-

(10) have in place for the purpose of responding to the reporting of medical neglect (including instances of withholding of medically indicated treatment from disabled infants with life-threatening conditions), procedures or programs, or both (within the State child protective services system), to provide for-

(A) coordination and consultation with individuals designated by and within appropriate health-care facilities;

(B) prompt notification by individuals designated by and within appropriate health-care facilities of cases of suspected medical neglect (including instances of withholding of medically indicated treatment from disabled infants with life-threatening conditions); and

(C) authority, under State law, for the State child protective services system to pursue any legal remedies, including the authority to initiate legal proceedings in a court of competent jurisdiction, as may be necessary to prevent the withholding of medically indicated treatment from disabled infants with life-threatening conditions.

147. The only enforcement provision in the Child Abuse Prevention and Treatment Program Act is a provision allowing the Secretary of HHS to withhold funds from a state, after reasonable notice and an opportunity for a hearing, when the Secretary finds a failure to comply with any provisions of the Act. See 42 U.S.C. $\$ 5116 \mathrm{e}$ (1988). Cf. Note, Developments in the Law-Medical Technology and the Law, 103 Harv. L. Rev. 1519, 1592-93 (1990) (suggesting that procedural uncertainty and procedural safeguards may also limit the enforceability of the Amendments).

148. See Guillemin \& Holmstrom, supra note 18, at 281 ("The closed world of the Level Ill nursery may permit greater discretion than the rule allows.").

149. See id. at 141-42, 171-72 (describing NICU as a place where "[t]he influence of the law was ... kept at bay" and where staff interaction with parents was "based on 
hierarchical structure among physicians and nurses working in the NICU may tend to quell any dissension in the ranks regarding treatment or nontreatment decisions and thus prevent the reporting of nontreatment to state agencies. ${ }^{150}$

In light of these factors, the fact that federal monitors of the Amendments' implementation have questioned their effectiveness ${ }^{151}$ should come as no surprise. Nonetheless, the federal standards may have served a symbolic, if not practical, purpose of appeasing the antiabortion and disability rights groups that influenced their passage. ${ }^{152}$

Thus, the legal legacy of Baby Doe is one of uncertainty. Neither the viability nor the appropriateness of either of the federal government's responses to Baby Doe has been fully confirmed or denied. In the context of this uncertainty, Congress passed the Americans with Disabilities Act in 1990. Although neither the language of the ADA nor its legislative history makes express reference to nontreatment of disabled newborns, ${ }^{153}$ the ADA can and should be construed as prohibiting discriminatory nontreatment based on disability, in much the same way that section 504 can be construed as prohibiting nontreatment based on handicap. It is into this arena of legal uncertainty on the question of nontreatment decisions that the HIV-infected infant need-

the ... assumption that ... power of guardianship passes to the physicians on admission").

150. See id. at 118-24 (discussing interactions between physicians, residents, nurses, and other hospital staff in the NiCU).

151. See U.S. Comm'n on Civil Rights, Medical Discrimination Against Children with Disabilities 148-49, 152 (1989) [hereinafter U.S. Comm'n on Civil Rights] (finding "substantial failure" by state child protective agencies to enforce the Amendments and charging that "discriminatory denial of medical treatment . . . has not dramatically changed since the implementation of the Child Abuse Amendments of 1984"); Newman, supra note 2, at 9 ("It is not clear what impact the Federal legislation and increased State responsibility have had on the incidence or handling of baby Doe reports." ") (quoting Office of Inspector General, U.S. Dep't of Health and Human Services, Survey of State Baby Doe Programs 13 (1987)).

Of course, determining "effectiveness" requires identifying a base point from which to measure change. Since there is little agreement over the extent of selective nontreatment prior to the Child Abuse Amendments, the debate over the effectiveness of the Amendments begins to sound like an argument over whether a glass of water is half empty or half full. Compare Bopp \& Nimz, supra note 134, at 94-95 (citing Civil Rights Commission's findings of widespread failures by state agencies to implement the Amendments and of the agencies' abdication of their authority to hospital infant care review committees, hospital staffs, and medical associations) with Arthur L. Caplan, Hard Cases Make Bad Law: The Legacy of the Baby Doe Controversy, in Compelled Compassion, supra note 2, at 105, 113 ("The information that does exist [regarding the treatment of newborns] does not support the view that federal intervention was necessary, nor does it support the position that federal action has been beneficial for infants or their families.").

152. See, e.g., Guillemin \& Holmstrom, supra note 18, at 255, 281 (discussing influence of Life, an anti-abortion pressure group, in prosecution of pediatrician for nontreatment of infant with Down syndrome); Mnookin, supra note 91, at 675-76.

153. See infra text accompanying note 252. 
ing medical treatment is thrown. In light of the mixed legal responses to selective nontreatment, we need also to consider what the Baby Doe controversy taught us regarding the ethics of selective nontreatment and whether those ethical lessons can lend normative insights to our legal analysis of selective nontreatment based on HIV infection.

\section{The Ethical Legacy of Baby DoE}

A fundamental ethical question posed by both the Baby Doe controversy and the hypothetical scenarios of selective nontreatment revealed by the JAMA survey is what standards should guide medical decision-makers making treatment choices for an infant incapable of making its own autonomous choices. The general model of medical decision-making, discussed below, requires physician deference to patient autonomy and thus does not suit treatment decision-making for a disabled infant. The ethical principle of respect for autonomy is premised on a decision-maker who is capable of making decisions that are voluntary and that are informed by his own values and priorities. ${ }^{154} \mathrm{By}$ definition, an infant, whether or not disabled, has no decisional autonomy that demands respect.

This lack of autonomy has two main implications with respect to disabled infants. First, someone other than the patient must choose among treatment options. ${ }^{155}$ Second, that decision-maker may need ethical guidance in determining what treatment option is preferable for a particular infant. In terms of the relevance of that ethical guidance to legal analysis, identifying appropriate ethical norms for making treatment decisions for disabled infants may help us decide whether and how existing legal standards could be applied consistently with ethical decision-making for HIV-infected infants.

For example, Part VI proposes a standard for interpreting the ADA's sweeping mandate as applying to nonparental decision-making for HIV-infected infants. In light of the ADA's extremely broad and inclusive general prohibitions, as contrasted with the failure of either the statute itself or its legislative bistory to address specifically this particular application, Part VI must confront an essentially normative

154. See generally Tom L. Beauchamp \& James F. Childress, Principles of Biomedical Ethics 67-71 (3d ed. 1989) (refiguring the concept of autonomy for use in moral theory). The principle is extended, however, to respecting the former autonomy of patients who are no longer competent to make autonomous choices. Under a "substituted judgment" standard, courts have deferred to refusals of treatment based upon a now-incompetent patient's past expressions of values and priorities or of desires regarding medical treatment. See, e.g., In re Storar, 420 N.E.2d 64, 68, 72 (N.Y. 1981).

155. The ordinary presumption is that parents are the proper decision-makers regarding medical treatment for minor children. See Joseph Goldstein, Medical Care for the Child at Risk: On State Supervention of Parental Autonomy, 86 Yale L.J. 645, 645-46 (1977). Much of the commentary on the Baby Doe controversy occupied itself with whether that presumption should remain intact in cases involving severely disabled newborns. 
question: Should the ADA's indeterminacy be resolved by interpreting the statute to apply to nonparental treatment choices for infants with HIV and to medical decision-making more generally? Considering the ethical debate sparked by Baby Doe's death can both help us answer this question and suggest an answer to a related question: What should it mean to "apply the ADA" in the context of medical decision-making? More specifically, having considered ethical arguments regarding the appropriateness of selective nontreatment based on disability will enable us better to assess the normative implications of the different ways that the ADA could be interpreted as applying (or not) to medical decision-making, particularly decision-making for infants with HIV infection.

Before plunging into Baby Doe's ethical maelstrom, ${ }^{156}$ however, a brief examination of ethical standards for medical decision-making in general is in order. As a general proposition, the intrinsic purpose of medicine is to promote health, a goal more specifically described as seeking to preserve life and to eliminate or lessen pain and suffering, all while respecting patients' autonomy. Because these goals may at times conflict, for example when measures necessary to preserve a patient's life will increase her physical suffering, they should be pursued in a balanced manner. In other words, no single goal will always take precedence over the others. ${ }^{157}$

In deciding what treatment to recommend for a patient, a physician should adhere to the principles of beneficence and

156. While the issue discussed in the text is substantive in nature, the other central issue raised by selective nontreatment is procedural: Who is the appropriate party to decide whether a disabled newborn should receive life-saving medical treatment? Secondary, but difficult, issues raised by selective nontreatment include the following: Is there any ethical distinction between withholding treatment and withdrawing treatment once it has been commenced? Can nutrition and hydration ethically be withheld or withdrawn? What role should institutional ethics committees play in the decision-making process? What are the respective obligations of the family and society to care for a disabled infant whose life is saved by medical treatment? Can the costs of treatment ethically be considered in deciding whether to treat? For a comprehensive analysis of these ethical issues, see Newborns Project, supra note 2.

157. See David C. Blake, State Interests in Terminating Medical Treatment, Hastings Center Rep., May-June 1989, at 5, 6. The balancing of these sometimes incompatible goals occurs most clearly in cases where patients seek to refuse medical treatment that would prolong their lives, but cause either physical or mental suffering that the patient is unwilling to bear. If the patient is competent, courts almost invariably respect the patient's autonomous choice to refuse treatment. See, e.g., Bouvia v. Superior Court, 179 Cal. App. 3d 1127, 1137 (Cal. Ct. App. 1986); Public Health Trust of Dade County v. Wons, 541 So. 2d 96, 97-98 (Fla. 1989). If the patient is incompetent, the courts are likely either (1) to seek to determine, based on evidence regarding the patient's expressed desires and values, what decision regarding treatment the patient would make if competent (the "substituted judgment" test) or (2) to decide what treatment decision is in the patient's "best interests." See In re Conroy, 486 A.2d 1209, 1229-30 (N.J. 1985); In re Storar, 420 N.E.2d at 68, 72. 
nonmaleficence. ${ }^{158}$ Both principles are embodied in the ethical precept that physicians should make decisions consistent with the best interests of the patient. ${ }^{159}$ This norm, which is concordant with the standard of care applied in medical malpractice cases, ${ }^{160}$ requires that the benefits expected to flow from proposed medical treatment outweigh any harms that may accompany the treatment. ${ }^{161}$ The best interests of the patient

158. The principle of beneficence requires that a moral agent act to promote good or minimize or prevent harm. The principle of nonmaleficence requires that an agent refrain from doing harm. See Beauchamp \& Childress, supra note 154, at 194-95. Of these two general principles, the latter comports with the primary principle of medical ethics: "First, do no harm." Id. at 120.

Until the past few decades, physicians were expected to rely exclusively on the principles of beneficence and nonmaleficence in making decisions for the benefit of a patient. In the past twenty years, however, patients have demanded, and medical ethics has come to recognize, that the patient, not his physician, should be primarily responsible for determining the patient's best interests. Consequently, many of the ethical issues that physicians face today arise from a perceived conflict between the physician's ethical obligations both to respect the patient's autonomous decision regarding treatment and to pursue the treatment that the physician believes is in the patient's best interests. See generally Edmund D. Pellegrino \& David C. Thomasma, The Conflict Between Autonomy and Beneficence in Medical Ethics: Proposal for a Resolution, 3 J. Contemp. Health L. \& Pol'y 23 (1987) (proposing beneficence model of medical treatment as alternative to patient autonomy and medical paternalism models).

159. Evidence that the medical profession's fundamental ethical obligation lies in promoting the patient's well-being is present throughout the American Medical Association's code of ethics. See, e.g., AMA Council on Ethical \& Jud. Aff., Current Opinions, op. 2.17 (1989) (stating that in making treatment decisions concerning the severely ill, the primary consideration is the best interests of the patient and not those of the family or society); id. op. 2.20 (specifying that when a patient is incompetent to act in his own behalf and did not indicate his views on withholding or withdrawing lifeprolonging medical treatment prior to becoming incompetent, the family or the patient's proxy, with the physician's aid, must act in the patient's best interest); AMA Council on Ethical \& Jud. Aff., Reports, op. 2.22 (1987) (listing as one of seven considerations in drafting a statement of policy regarding do not resuscitate orders: " $[t]$ he social commitment of a physician is to sustain life despite disabilities, handicaps, or advanced age, except in circumstances where efforts to prolong life would be inhumane and unconscionable" and are not in accord with the patient's best interests.).

160. Cf. Edward B. Hirshfeld, Should Ethical and Legal Standards for Physicians be Changed to Accommodate New Models for Rationing Health Care?, $140 \mathrm{U}$. Pa. L. Rev. 1809, 1816 (1992) ("[O]ne major theme followed [by medicine and law] is that the best interests of the patient should be the overriding concern when determining what care should be provided.").

161. See Beauchamp \& Childress, supra note 154, at 228-34; Rhoden, supra note 2, at 1314 (argning that dying newborns may not live long enough to develop an ability to appreciate their last days in a way that outweighs the pain of present medical procedures). Although many people may think of medical treatment as being inherently beneficial, most treatments carry with them some level of physical invasiveness, pain, risk of side effects, or risk of iatrogenic injury or nosocomial infection. See, e.g., Rhoden, supra note 2, at 1322. An iatrogenic injury is any adverse condition suffered by a patient as a result of medical treatment, especially infections acquired during the course of treatment, and a nosocomial infection is an infection acquired after admittance to the hospital. See Dorland's Illustrated Medical Dictionary 812, 1151 (27th ed. 1988). Thus, few medical treatments can be regarded as purely benign. Moreover, neither 
standard also prescribes that a physician's treatment recommendation reflect an individualized assessment of the patient's interests ${ }^{162}$ and that those interests take priority over any conflicting interests of a health care provider in personal financial benefit or of society in conserving or allocating scarce resources. ${ }^{163}$

Because these general norms do not fit a situation involving medi-

medical ethics nor the legal standard of care necessarily require a physician to recommend every procedure or treatment that potentially offers some benefit, no matter how minimal or how uncertain, to the patient. Thus, some medical care that offers some potential benefit may nonetheless be deemed unnecessary. See Hirshfeld, supra note 160, at 1828-31. But see Helling v. Carey, 519 P.2d 981, 983 (Wash. 1974) (holding that standard of care required glaucoma testing for young patient even though glaucoma occurs in only one out of every 25,000 people under age forty).

162. See Hirshfeld, supra note 160, at 1817-18 ("Decisions about necessity . . . are based on case by case determinations . . . as opposed to the application of a set of predetermined criteria."). Çf. AMA Council on Ethical \& Jud. Aff., Current Opinions, op. 2.20 (1992) (directing physicians to consider such factors as "the possibility for extending life under humane and comfortable conditions; the patient's values about life and the way it should be lived; and the patient's attitudes toward sickness, suffering, medical procedures, and death").

163. See AMA, supra note 162, op. 2.09 ("[S]ocial policy expects that concern for the care the patient receives will be the physician's first consideration."); id. op. 4.04 ("[W]here the economic interests of the hospital are in conflict with patient welfare, patient welfare takes priority."); id. op. 8.03 ("If a conflict develops between the physician's financial interest and the physician's responsibilities to the patient, the conflict must be resolved to the patient's benefit.").

Of course, the current debates over whether and how to ration scarce health care resources suggest that situations may exist when, as a matter of social policy, a patient's interest in receiving a particular beneficial medical treatment may be subordinated to society's interests in conserving or efficiently allocating resources. For discussions of rationing from a variety of perspectives, see generally Symposium, The Law and Policy of Health Care Rationing: Models and Accountability, 140 U. Pa. L. Rev. 1505 (1992). A distinction can and should be made, however, between decisions made by policymakers, whose charge is to act in the interests of society, and decisions made by physicians, whose charge is to act in the interests of individual patients. Cf. Hirshfeld, supra note 160, at 1840-42 (suggesting that a societal decision to engage in explicit rationing need not be incompatible with physician decision-making based on a patient's best interests). This distinction is discussed further infra in the text accompanying notes 291-302.

Some commentators, however, suggest that the medical malpractice standard of care should be changed to accommodate current efforts towards cost containment in health care and new models of health care delivery like health maintenance organizations. See, e.g., Mark A. Hall, The Malpractice Standard under Health Care Cost Containment, 17 L. Med. \& Health Care 347, 347-52 (1989) (examining the view of commentators on the role of cost containment in establishing a standard of care for physicians in malpractice cases); E. Haavi Morreim, Cost Containment and the Standard of Medical Care, 75 Cal. L. Rev. 1719, 1745-63 (1987) (discussing several ways in which the current malpractice standard may be modified). But see Andrea J. Lairson, Reexamining the Physician's Duty of Care in Response to Medicare's Prospective Payment System, 62 Wash. L. Rev. 791, 804 (1987) (arguing against changing the standard of care to take into account economic considerations). Changes to the medical malpractice standard of care would seem implicitly to suggest a change in a physician's ethical obligations. 
cal decisions for a nonautonomous newborn, however, it is necessary to extrapolate from these norms to identify the appropriate standard for a decision-maker to adhere to in such a situation. Although commentators have advocated a variety of substantive standards against which to judge treatment decisions for disabled infants, most of those standards can be described as reflecting either a "sanctity of life" approach or "quality of life" approach. ${ }^{164}$

\section{A. Sanctity of Life Approaches}

Those who condemn selective nontreatment on sanctity of life grounds have staked out two basic positions. The more extreme of the two positions insists that, because all life is sacred, treatment of a disabled infant is ethically mandated as long as the infant is alive, no matter how disabled or how near death the infant might be. This vitalist approach has few adherents, in part because it loses any appeal it has when applied to an infant in the process of dying. In that situation, vitalists would argue that decision-makers are morally required to subject a dying infant to painful and invasive medical interventions until the moment of death, even though the interventions have no prospect of saving the infant's life. ${ }^{165}$

Most advocates of a sanctity of life approach find no moral requirement that medical interventions be used to prolong the dying of a terminally ill infant. ${ }^{166}$ They do argue, however, that because each infant's life has intrinsic value, no infant should be allowed to die from selective nontreatment simply because of a disability or an expected poor quality of life. According to this view, therefore, the only morally relevant consideration in deciding whether to provide medical treatment to an infant who is not dying is whether the treatment offers a medical benefit to the infant. ${ }^{167}$ The Child Abuse Amendments reflect this "medical indications" approach, for example, in their provision

164. The following discussion draws heavily from the Hastings Center Newborns Project, supra note 2, at 13 (Section 3: Standards of Judgment for Treatment). The Hastings Center Newborns Project assembled a group of experts from disability groups, family self-help associations, right-to-life associations, medical societies, state and federal agencies, and academia to discuss the ethics of neonatal care.

165. See id. at 13-14.

166. For example, according to former Surgeon General C. Everett Koop: "For such [dying] infants, neither medicine nor law can be of any belp, and neither medicine nor law should prolong these infants' process of dying." Treatment of lnfants with Handicapping Conditions: Hearings Before Subcomm. on Select Education House Comm. on Education and Labor, 97th Cong., 2d Sess. 5 (1982).

167. See Newborns Project, supra note 2, at 14; Paul Ramsey, Ethics at the Edges of Life: Medical and Legal Intersections 154, 181-88 (1978). This stance is not consistent with the "best interests" approach, as discussed infra at text accompanying notes 177-184, because it does not inquire whether the benefit received from the treatment justifies the burdens imposed by the treatment. Proponents of this approach reject a consideration of burdens as requiring an improper reference to the infant's future quality of life. See Arras, supra note 92, at 96. 
that a failure to provide "medically indicated treatment" (i.e., treatment deemed most likely to ameliorate or correct an infant's life-threatening conditions) will constitute medical neglect unless the treatment would merely prolong dying. ${ }^{168}$

In addition, because it decrees willful blindness to an infant's disability, the medical indications approach appears to reflect the principle of nondiscrimination, that is, that no one should be denied benefits on the basis of a characteristic that is morally irrelevant to the purpose of the distribution of benefits in question. ${ }^{169}$ Critics of this approach, however, suggest that while an infant's Down syndrome may be morally irrelevant to deciding whether she should receive relatively routine lifesaving corrective surgery for an esophageal blockage, not all disabilities that an infant may suffer are in fact morally irrelevant to treatment decisions for the infant. For example, a disability may so compromise an infant's health, life expectancy, or potential cognitive ability that the pain and risk of complications posed by a contemplated treatment are so great that the treatment offers no net benefit to the infant and therefore is not truly in the infant's best interests. ${ }^{170}$ Thus, critics reject the medical indications approach as an overly simplistic response to the complexities of medical decision-making for disabled infants. ${ }^{171}$

\section{B. Quality of Life Approaches}

While the label "sanctity of life" can be applied to two different substantive standards for judging the morality of treatment decisions for disabled infants, the phrase "quality of life" describes a wider diversity of ethical standards. At the end of the spectrum furthest from either sanctity of life approach are those commentators who argue not only that an infant's expected future quality of life is an ethically valid

168. See 42 U.S.C. $\$ 5106 g(10)$ (1988). For a discussion of the Amendments and their other exceptions to the treatment requirement in the context of treatment for HIVinfected infants, see infra notes 190-204 and accompanying text. But see Rhoden, supra note 2, at 1313-I7 (arguing that the Amendments' exceptions implicitly recognize the validity of quality of life considerations).

169. See Arras, supra note 92, at 97. In this sense, the medical indications approach is consistent with the antidiscrimination approach of HHS's regnlations under $\S 504$ of the Rehabilitation Act. See id. at 96-97, 100.

170. For further discussion of the possible moral relevance of disabilities to treatment decisions, see infra Part VI.B.2.

171. See Newborns Project, supra note 2, at 14; Arras, supra note 92, at 98-99 (arguing that while the death of Baby Doe was morally objectionable, the Reagan administration's response was to propound a "hopelessly simplistic rule"). Professor Nancy Rhoden made the following observation:

It is crucial to recognize that making treatment decisions [for infants requiring intensive care] is a complex task, and that this complexity is a function of th[e] wide range of possible disorders and treatment dilemmas they present. All too often, analyses of this problem oversimplify its medical parameters by focusing on only one or two birth defects (e.g., Down's syndrome).

Rhoden, supra note 2, at 1287 . 
consideration, but that assessing quality of life should include a utilitarian consideration of how the infant's life will affect other individuals and society, including the burdens that caring for a disabled infant may place on the infant's family. ${ }^{172}$

An alternative quality of life standard might be used to measure an individual infant's life against some norm of an "acceptable life." From this perspective, the Child Abuse Amendment's exception for an irreversibly comatose infant arguably reflects a quality of life standard with the threshold for what constitutes an "acceptable life" placed quite low. ${ }^{173}$ Other advocates of such an approach, however, could raise the threshold to an objectionably high level. ${ }^{174}$

Consequently, the danger of quality of life standards that either consider the social worth of a disabled infant or measure the infant's life against an "acceptable" life lies in their subjectivity and variability. These characteristics describe a moral landscape in which "slippery slope" objections carry considerable force, particularly when surrounding circumstances (such as movements towards health care rationing and the social stigma attached to HIV infection and IVDU) increase the danger that morally unacceptable decisions may be made. ${ }^{175}$ In other words, once we accept that the burdens an individual imposes on soci-

172. See Newborns Project, supra note 2, at 14. Professor George Smith describes the utilitarian ethic in the following terms:

Life-viewed as a human resource-should be developed and preserved along those lines which allow for the achievement of its fullest potential for total economic realization, maximization or productivity. . . . Viewed thusly, attainment of the quality of purposeful, humane living becomes a coordinate or complement to total economic utility.

George P. Smith, Il, Death Be Not Proud: Medical, Ethical and Legal Dilemmas in Resource Allocation, 3 J. Contemp. Health L. \& Pol'y 47, 63 (1987). But see James F. Childress, Triage in Neonatal Intensive Care: The Limitations of a Metaphor, $69 \mathrm{Va}$. L. Rev. 547, 556 (1983) (arguing that considerations of social utility are inappropriate in allocating resources for neonatal intensive care).

173. See Newborns Project, supra note 2, at 15. Nancy Rhoden made the point cogently:

The exception that most clearly rests on quality of life concerns . . . is the one that allows nontreatment for comatose infants .... .

The reason for this exception is that unconscious infants have no potential

for human life as we know it .... When the capacity to consciously experience

life is wholly absent, nontreatment decisions are relatively uncontroversial.

Rhoden, supra note 2, at 1316-17. Although Rhoden's approach resembles a version of a best interests approach, she can also be seen as adopting a standard for what constitutes a minimally "acceptable" life: "Any disorder that reliably restricts life to infancy (e.g., a few years) will most likely render its victims unable to experience those characteristically human pleasures of relating to their environment and to others. Thus, withholding aggressive treatment from such infants . . can be justified." ld. at 1319.

174. See, e.g., Lorber, supra note 86, at 204 (suggesting that an infant's predicted ability to work or marry may be a factor for guiding the treatment decision).

175. Cf. Frederick Schauer, Slippery Slopes, 99 Harv. L. Rev. 361, 381-82 (1985) (arguing that persuasive slippery slope arguments must be based on empirical circumstances that skew the risk of dangerous decisions). 
ety are a valid consideration in deciding whether to provide medical treatment to that individual, how are we to assess how severe the burden must be before we ethically can consider it? Should the burdens a prisoner or a chronically mentally ill person imposes factor into decisions whether those persons should receive life-saving medical treatment? If not, where and how should the line be drawn? ${ }^{176}$

Another approach accepts the validity of considering an infant's quality of life, but attempts to conduct the assessment solely from the infant's own perspective. This quality of life approach directs that treatment decisions accord with the "best interests of the child," so that the only relevant benefits and burdens to be weighed are those experienced by the child. While resembling the "medical indications" approach discussed above, this best interests of the child standard recognizes that in some cases medical treatment and continued life may impose a burden on an infant that is not outweighed by any benefits to be gained by continued life. Moreover, this standard accepts that an infant's mental and physical condition, including the effects of any disability, should weigh in the benefits-burdens calculus.

Not only does the best interests standard limit consideration of benefits and burdens to those experienced by the infant; it also seeks to weigh alternatives from the disabled infant's point of view. In other words, the proper comparison is not between the quality of life experienced by a "normal" infant and the quality of life expected for this disabled infant, but between this infant's prospective quality of life and no life at all. Thus, a severe disability may justify withholding medical

176. The most notorious historical example of a society sliding down a slippery moral slope is, of course, that of Germany in the 1920s through the 1940s. This example holds particular power in the context of selective nontreatment because the Nazi practice of killing those whose lives were deemed not worth living was rooted in the Weimar Republic's introduction of euthanasia as a "treatment option." The idea that selected categories of patients may benefit from euthanasia developed in Germany during the 1920s. These categories included willing patients competent to make such a decision, as well as those whose decision would be made for them such as the disabled, particularly disabled children. Though proponents emphasized the compassionate nature of euthanasia, they also justified it by focusing on the cost and burden imposed on society as a result of maintaining the lives of the sick and disabled. The latter justification developed over time, especially in relation to disabled children who would require a lifetime of care. Reports began to appear comparing the cost of educating the disabled child with that of the "normal child," criticizing the undue burden placed on the community in caring for the disabled. Thus, the value and cost of lives were weighed and balanced in considering "treatment options."

Over time, novels and movies joined scholarly works in advocating euthanasia. Ultimately, the general public and medical community bowed to the propaganda and accepted it. Under the Nazi regime, an advisory committee was formed to organize a program for terminating the life of those children who were deemed to have no prospect of a meaningful life. Means of death used included starvation and failure to provide heat-means meant to sidestep any accusations of murder since they were simply the withholding of treatment. See Rita L. Marker et al., Euthanasia: A Historical Overview, 2 Md. J. Contemp. Legal Issues 257, 265-275 (1991). 
treatment from an infant, but only when the burdens resulting from the disability are so extreme that, from the infant's perspective, continued life offers no overriding benefit. ${ }^{177}$

While even advocates of a best interests standard have acknowledged its "staggering problems of interpretation and application,"178 including the potential influence of the decision-maker's subjective biases, many commentators have embraced it as the morally preferable approach to making treatment decisions because it seeks to focus exclusively and realistically on the infant's welfare. ${ }^{179}$

By focusing on the child's interests, this standard avoids morally dubious utilitarian justifications based on the well-being of other interested parties, such as parents, siblings, or even of society at large; and by giving full weight to the child's interests, this approach can justify nontreatment in certain cases without having to make the (usually pernicious) assumption that the child is a nonperson with no standing in the human community. 180

This approach also best satisfies the principle of justice by holding medical decisions for disabled newborns to the same standard-a best interests standard-as medical decisions for other noncompetent patients who have not previously expressed their autonomous desires regarding treatment choices. ${ }^{181}$

177. See President's Comm'n for the Study of Ethical Problems in Medical and Biomedical and Behavior Research, Deciding to Forego Life-Sustaining Treatment: A Report on the Ethical, Medical and Legal Issues in Treatment Decisions 218-19 (1983) [hereinafter President's Commission].

178. Arras, supra note 92 , at 106; see also Rhoden, supra note 2, at 1307-12 (discussing interpretive problems of best interests standard as set forth by President's Commission). One of the difficulties inherent in the best interests approach-that of predicting any infant's future quality of life-is complicated by the prognostic uncertainty that physicians face with respect to many infants for whom treatment decisions must be made. See President's Commission, supra note 177, at 220 . For further discussion of the implications of prognostic uncertainty, see infra Part lV.C.

179. See Newborns Project, supra note 2, at 15; President's Commission, supra note 177, at 215-16 (arguing that child's best interests should override parental decision-making rights when the two conflict); Weir, supra note 2, at 17-18. Weir describes the essence of decision-making under a best interests standard: "Such decisions should focus on the child's medical condition, concern suffering and irremediable handicap rather than projected social worth, and involve comparative judgments about the continuation of the child's injurious existence as opposed to the child's nonexistence." ld.

180. Arras, supra note 92, at 105-06. Arras's reference to "nonpersons" responds to the argument advanced by, for example, Tooley, who would find death by selective nontreatment morally acceptable on the ground that severely disabled newborns, and in fact all newborns, are not "persons" entitled to moral consideration because they lack qualities necessary for personhood, chief among which are the capacities to have a concept of self and to entertain desires about one's future. See Michael Tooley, Abortion and Infanticide, 2 Phil. \& Pub. Aff. 37, 62-64 (1972).

181. See, e.g., In re Rosebush, 491 N.W.2d 633, 640 (Mich. Ct. App. 1992) (finding that decision-makers should use best interests standard in cases involving never- 
One criticism of using a best interests standard to guide decisionmaking for severely disabled infants is that its calculus of weighing burdens against benefits is inapt for an infant whose prognosis is "bereft of any distinctly human potentiality," for example, a comatose infant or an infant who is profoundly retarded, blind, and deaf. ${ }^{182}$ ln other words, the argument goes, a patient who lacks any potential for present or future human relationsbips is properly described as having no real interests at all, except to be free from pain. ${ }^{183}$ Because such an infant has no interests of its own to which a best interests standard can apply, allowing the interests of others to weigh in that infant's treatment decision is morally acceptable. The general applicability of a best interests standard may be limited by infants who are so severely neurologically impaired that they have no relational potential and therefore no interests of their own. ${ }^{184}$

competent persons or immature minors); In re Conroy, 486 A.2d 1209, 1232 (N.J. 1985) (holding that in absence of trustworthy evidence that a formerly competent patient would have refused treatment, treatment may be withheld if "the net burdens of the patient's life with the treatment ... clearly and markedly outweigh the benefits that the patient derives from life"); In re L.W., 482 N.W.2d 60, 63 (Wis. 1992) (holding that decision whether to withdraw treatment for patient with a long history of schizophrenia, who may never have been competent and who is now in persistent vegetative state, could be made by guardian consistently with patient's best interests). These cases reflect the principle that, except to the extent respect for a patient's autonomous choice dictates otherwise, all medical decisions should be made in the best interests of the patient. Cf. Rhoden, supra note 2, at 1337 ("Decisions involving patients other than newborns thus show that reasonable quality of life judgments, even if not designated as such, are appropriate and lawful. This must also be true with infants ....").

What a patient's best interests are has been described as follows:

[T] he concept of "best interests" can be used to capture the most fundamental future interest that persons have when they are patients, namely, an interest in not being harmed on balance during the course of medical treatment. For most patients in most clinical situations, this vital interest in not being harmed on balance means that they prefer continued life to death-unless intractable pain and other suffering have made continued life more harmful than the prospect of death.

Weir, supra note 2, at 21.

182. Arras, supra note 92 , at 119-21.

183. See Richard A. McCormick, To Save or Let Die, 229 JAMA 172 (1974) (arguing that in Judeo-Christian tradition, life is not to be preserved for its own sake, but for capacity of the person to form human relationships).

184. See Newborns Project, supra note 2, at 15-16. Arras describes the case of the profoundly neurologically impaired infant as illustrating the limits of the best interests standard:

The presence or absence of such characteristics as the ability to think, to communicate, to give and receive love, seems to be highly relevant from a moral point of view. Indeed, in the absence of these capacities, it is problematical in the extreme how we can attribute any human interests to the child on which a best-interest standard might operate. By narrowing the range of meaningful data to the presence or absence of unrelievable pain, the best interest standard consigns itself in extreme cases to operating in a moral 


\section{Process and the Problem of Uncertainty}

Compounding the difficulty of settling on the ethically correct substantive norm to guide medical treatment decisions for disabled newborns is the inextricably related issue of how and when decisionmakers should apply the chosen norm. Because of the uncertainty inherent in establishing prognoses and predicting the risks of treatment, treatment decisions for a disabled infant must be made without complete information that would allow confident prediction of the infant's future quality of life. ${ }^{185}$

This uncertainty has led to three decision-making strategies for imperiled newborns: (1) treat an infant until it is certain that continued treatment cannot benefit the infant (the "wait until certainty" approach); (2) decide whether to start treating an infant based on a statistical prediction of its likelihood of benefitting from treatment (tbe

vacuum. The result is an indiscriminate mandate to treat, to keep alive, that flies in the face of common sense.

Arras, supra note 92, at 121 .

In proposing a set of guidelines for when treatment is nonobligatory, Nancy Rhoden expanded the concept of relational capacity to include an assessment of how the burdens of medical treatment affect the ability of the infant to "experience those characteristically human pleasures of relating to their environment and to others." Rhoden, supra note 2, at 1319 . Noting that virtually all medical treatments impose burdens, Rhoden proposed that aggressive treatment should not be mandatory if an infant:

(1) is in the process of dying; (2) will never be conscious; (3) will suffer unremitting pain; (4) can live only with major, highly restrictive technology which is intended to be temporary (e.g., artificial ventilation); (5) cannot live past infancy (i.e., a few years); or (6) lacks potential for human interaction as a result of profound retardation.

Id. at 1322-23.

185. Uncertainty regarding the prognoses of disabled newborns is but a particular example of the uncertainty that characterizes medical decision-making generally:

[M]edicine is inherently a probabilistic profession. Diagnoses are rarely 100 percent certain and in spite of the traditional jargon, very few diagnoses are ever "ruled out." Prognosis ... is rarely certain ... because all treatments vary in their efficacy from patient to patient and from time to time. Furthermore, the risks of treatment are not always predictable. ...

Diagnostic and prognostic uncertainty can be generated by a data base which is incomplete, unclear or inconsistent.

Newborns Project, supra note 2, at 10. The rapid development of new technologies for treating newborns has heightened this general uncertainty, particularly in the context of neonates who are either extremely premature or severely asphyxiated at birth, two of the most common problems that require neonatal intensive care and treatment decisions for a newborn. See Nancy K. Rhoden, Treating Baby Doe: The Ethics of Uncertainty, 16 Hastings Center Rep., Aug. 1986, at 34; cf. Carol L. Berseth, Ethical Dilemmas in the Neonatal Intensive Care Unit, 62 Mayo Clinic Proc. 67, 68 (1987) ("[A]Ithough statistics can provide the family and the physician with general perceptions of survival and morbidity, such statistics cannot specifically predict the survival or morbidity for any individual infant."). Likewise, as discussed supra text accompanying notes 49-65, the prognosis for infants infected with HIV is extremely uncertain. 
"statistical prognostic strategy"); and (3) start treating an infant but constantly reevaluate, based on information accumulated in the course of treatment, whether continuing treatment is likely to benefit the infant (the "individualized prognostic strategy"). ${ }^{186}$ Although positive aspects commend each strategy, ${ }^{187}$ the individualized prognostic strategy is morally preferable because it focuses on the situation of the particular infant whose life is at stake and thus comports with the ethical precept that treatment decisions should be based on an individualized assessment of the patient's interests. ${ }^{188}$ As a practical matter, the individualized prognostic strategy means that the decision-maker responsible for making treatment choices-whether the infant's natural parent, a foster parent, a physician, or whoever-should assess on an ongoing basis whether the provision or withholding of treatment is in the infant's best interests. ${ }^{189}$

In conclusion, based on the foregoing discussion, combining the best interests standard with an individualized prognostic strategy appears to offer the ethically preferable approach to making medical treatment decisions for disabled infants. In other words, decision-makers should seek only to further the infant's own interests and should reevaluate treatment decisions as accumulated information lends greater certainty to the nature of those interests. The question that remains for us to address, however, is whether our ethical conclusion 11-12.

186. See Rhoden, supra note 185 , at 38-40; Newborns Project, supra note 2, at

187. Both the "wait until certainty" approach and the "statistical prognostic strategy" seek to pursue a consistent, plausible goal. The former approach seeks to ensure that all infants who could receive an overall benefit from treatment not be allowed to die, i.e., it errs on the side of life. The latter approach, by contrast, seeks to minimize the likelihood of any infants surviving with unacceptable impairments. See Newborns Project, supra note 2, at 12-13.

188. See Rhoden, supra note 185 , at $38-40$. Rhoden also endorsed the individualized approach because using it in individual cases will entail the agonizing deliberations that are commensurate with the moral weight of the questions involved. See id. at 40; see also Newborns Project, supra note 2, at 13 ("[W]here mistakes at either end are so serious, it is morally preferable to decide on the basis of the individual infant's prognosis.").

189. Although the individualized prognostic strategy is ethically preferable and consistent with the philosophy of the ADA, see infra note 279 and accompanying text, it may prove expensive, both in terms of time and energy allocated to decision-making and the resources allocated to the resulting treatment. Thus, situations may exist when this mode of decision-making, while morally preferable, is practically infeasible. For example, a state social worker may be practically unable constantly to reassess all the medical information regarding numerous ill children in foster care under her supervision. Nonetheless, to the extent the state agency is compelled to depart from using an individualized prognostic strategy in making decisions for its wards, a more time- or cost-effective strategy should be used for all children under the state's care and not simply for children with H1V infection or other disabilities. See infra notes 294-296, 301 and accompanying text. 
can help illuminate the applicability of existing law to medical decisionmaking for infants infected with HIV.

\section{Applying the Lessons of History: The HiV-Infected Infant AND CHILd WELFARE LAW}

Having recognized the ethically problematic nature of selective nontreatment and identified the preferable ethical norms for gniding treatment decisions for disabled infants, including infants infected with HIV, we now must consider whether and how the law responds to selective nontreatment of HIV-infected infants. Assessing the legal status of medical treatment decisions for infants with HIV proves particularly difficult because of the mix of medical and social factors characterizing perinatal HIV infection. From a medical viewpoint, testing to detect HIV infection during the neonatal period is not yet reliable; a perinatally infected infant's prognosis is likely to be extremely uncertain and variable; and the infant's health may be compromised, independently of HIV infection, by prenatal exposure to drugs or inadequate prenatal care. From a social viewpoint, the infected infant faces a relatively large chance that decisions regarding its care will be made effectively not by its parents but by the state or a treating physician, and that those decisions may be influenced by such factors as negative attitudes towards persons with HIV, racial or ethnic bias, and a perceived need to ration medical resources. Are existing laws capable of supporting an appropriate and adequate response to the troubling practice of selective nontreatment in this setting? This Part begins to address that question by focusing on the applicability of federal child welfare law to the problem.

\section{A. Applying the CAA to Infants with HIV Infection}

Attempting to apply the Child Abuse Amendments and regulations ${ }^{190}$ to the case of an HIV-infected infant who also suffers some other life-threatening condition (i.e., the kind of case hypothesized by the JAMA survey) illustrates how elusive the precise bounds of the CAA's treatment mandate remain. The first step is relatively straightforward: The Amendments' basic standard prohibits a failure to provide whatever treatment for an infant's life-threatening conditions that reasonable medical judgment indicates will be most effective in ameliorating or correcting those conditions. ${ }^{191}$ Thus, unless an exception applies, an infant infected with HIV should receive whatever treatment is judged to be most effective for any concurrent medical conditions that he suffers.

One could argue, however, that withholding treatment from an

190. See supra notes $127-138$ and accompanying text for a description of the standards erected by the Amendments and their implementing regulations.

191. See 45 C.F.R. $\S 1340.15$ (b)(2) (1992). 
HIV-infected infant with a concurrent life-threatening condition falls within the exception for treatment that "would merely prolong dying, not be effective in ameliorating or correcting all of the infant's lifethreatening conditions, or otherwise be futile in terms of the survival of the infant." More plainly stated, because no cure for HIV or AIDS is currently known, treating an infected infant's other medical conditions arguably will not be effective in correcting all the infant's life-threatening conditions and, by postponing the inevitable death from AIDS, will merely prolong the infant's dying.

This argument, however, ignores the Department's interpretation of the exception. According to the Appendix, the inability to correct a condition that, while not life-threatening in the near future, may become life-threatening in the more distant future does not permit the withholding of treatment for another condition that can be corrected or ameliorated. 192 Likewise, the Department interprets the "merely prolong dying" prong of the exception as applying only when the infant's prognosis is for death in the near future, rather than in the more distant future. ${ }^{193}$

These distinctions between the "near future" and the "more distant future," while suggesting that the current inevitability of death from HIV infection does not, in and of itself, except an HIV-infected

192. The interpretative guidelines provide:

With respect to the context of a future life-threatening condition, it is the Department's interpretation that the term "not be effective in ameliorating or correcting all of the infant's life-threatening conditions" does not permit the withholding of treatment on the grounds that one or more of the infant's lifethreatening conditions, although not life-threatening in the near future, will become life-threatening in the more distant future.

45 C.F.R. § 1340 app. at 301 (1992).

193. In its proposed rule, the Department described the "merely prolong dying" provision as referring to "situations where death is imminent and treatment will do no more than postpone the act of dying." Id. at 300 . Because commentators objected to the sense of immediacy connoted by the term "imminent," the Department deleted the term from its final rule and did not adopt it for purposes of the interpretative guidelines. See id. at 300-01.

The guidelines do provide some further guidance on the meaning of the "merely prolong dying" provision:

The Department interprets the term "merely prolong dying" as referring to situations where the prognosis is for death and, in the treating physician's ... reasonable medical judgment, further or alternative treatment would not alter the prognosis in an extension of time that would not render the treatment futile.

Thus, the Department continues to interpret Congressional intent as not permitting the "merely prolong dying" provision to apply where many years of life will result from the provision of treatment. . . [T]he Department's interpretation is that reasonable medical judgments will be formed on the basis of knowledge about the condition(s) involved, the degree of inevitability of death, the probable effect of any potential treatments, the projected time period within which death will probably occur, and other pertinent factors. Id. 
infant from the protection of the CAA, fail to provide clear guidance ${ }^{194}$ on how to weigh an eventuality whose nature and timing are both uncertain. Hypothetically, if current data were to show that a majority of perinatally infected infants die within three years of birth, could physicians exercising reasonable medical judgment conclude that treating an infected infant's other conditions would "merely prolong dying," even though the number of perinatally infected children living to four or more years was increasing? 195 Is death in three years in the "near" or "more distant" future? Even if three years is considered tbe near future, how certain must the prognosis of such a near death be? 196

Turning to the exceptions for treatment that would be "futile in terms of the survival of the infant" or "virtually futile" and under the circumstances "inhumane" provides little respite from this ambiguity. Consistent with its explication of the other exceptions, the Department defines "virtually futile" as meaning that the "treatment is highly unlikely to prevent death in the near future."197 Again, we seem to be thrown back to speculating whether the certain death of an infant infected with HIV will occur in the near or more distant future.

Upon closer examination, however, the inclusion in the definition of "virtually futile" of a standard regarding the certainty of death suggests that withholding treatment is permissible only when the infant is

194. Analysis by commentators has likewise failed to suggest clear standards. See, e.g., Bopp \& Nimz, supra note 134, at 86 ("[T]reatment may not be withheld from any and every infant diagnosed as terminally ill. The child's death must be expected to occur relatively soon .....").

195. See supra text accompanying notes $49-64$ for a discussion of the uncertainty and variability of prognoses for perinatally infected infants.

196. The ambiguity in these exceptions is also illustrated by attempting to apply them to treatment for infants with Tay-Sachs disease, a metabolic disorder described supra note 22. While HHS has interpreted the CAA not to allow treatment for concurrent conditions to be withheld from infants with Tay-Sachs, commentators have argned that treating a remediable condition only to allow the child to suffer an agonizing and prolonged death is itself an act of abuse. See Terry Walman, Decision Making in the Neonatal Intensive Care Unit: The lmpact of the 1984 Child Abuse Amendments, in Compelled Compassion, supra note 2, at 299, 311; cf. Rhoden, supra note 2, at 1313-23 (arguing that to the extent exceptions permit discretion, they imply a recoguition of quality of life considerations).

197. 45 C.F.R. $\$ 1340$ app. at 302 (1992). The guidelines do not separately define the term "futile." The definition provided for "virtually futile," however, suggests that a treatment will be considered futile if it will not prevent the infant's death in the near future. The debate within the medical community over the meaning and the usefulness of the concept of futility limits its value as a legal standard. See, e.g., Robert D. Truog et al., The Problem With Futility, 326 New Eng. J. Med. 1560, 1561-62 (1992) (asserting that the notion of futility fails to provide an ethically coherent ground for limiting lifesustaining treatment as a result of (1) the difficulty in defining futility because of differences in social values, (2) the difficulty in estimating the probability of treatment's success, and (3) the possibility that assertions of futility may provide a method of allocating resources without fair procedures). This ambiguity may be partially avoided by the statute's express reference to futility "in terms of the survival of the infant." See 42 U.S.C. § $5106 \mathrm{~g}(10)$ (B)(iii) (1988). 
highly likely to die in the near future. ${ }^{198}$ While such a conclusion may be medically justified once an infant with HIV develops an opportunistic infection like PCP, ${ }^{199}$ it is far less certain for an infected infant who is asymptomatic or who displays milder symptoms. ${ }^{200}$ Because the prognosis and the estimated life expectancy for such an infant are uncertain, ranging from less than a year to more than five years, ${ }^{201}$ treating the infant's immediately life-threatening condition would seem to be neither futile nor virtually futile.

Although neither the exception for treatment that "merely prolong[s] dying" nor that for treatment "not effective in ameliorating or correcting all of the infant's life-threatening conditions" expresses an applicable standard of certitude, in light of the inherently probabilistic nature of medical judgments, it seems impossible to apply these exceptions without asking how certain the exception's applicability must be. The statute and regulations simply defer to "reasonable medical judgment" in this regard. For the regulations to make sense as a consistent whole, however, it seems a fairly high standard of certainty should be read into all the exceptions. ${ }^{202}$

198. Commentators on the proposed rules, which eventually became the Appendix, expressed concern that the "highly unlikely" standard required a level of certitude that is medically impossible. The Department responded that the pervasive reference to "reasonable medical judgment" in determining whether an exception to the treatment requirement is present obviates an "impossible or unrealistic standard of certitude." 45 C.F.R. \& 1340 app. at 302 (1992).

199. See supra text accompanying note 61 .

200. The first published opinion addressing treatment decisions for a perinatally infected child involved an infant who was diagnosed with HIV infection before her first birthday. See In re C.A., 603 N.E.2d 1171 (Ill. App. Ct. 1992), appeal denied, 610 N.E.2d 1264 (IIl. 1993). Born prematurely, the infant experienced interventricular hemorrhaging-a spontaneous rupture of weak blood vessels in the brain-and required a cardiac monitor and mechanical ventilation for weeks after birth. As she grew, C.A. became neurodevelopmentally delayed, but remained fully conscious and aware of her surroundings. The infant also suffered from necrotizing of the bowel, "an infection of the bowel that results in the death of tissue and requires removal." Id. at 1173-74. At the time of the trial, C.A. was receiving central line feedings, intravenous feeding, and tracheostomy, had already been resuscitated twice, and had had a catheter inserted into her heart. The court authorized the guardian appointed by the Illinois Department of Children and Family Services (DCFS) to consult with C.A.'s treating physicians and to enter a do not resuscitate (DNR) order when the guardian and the physicians believed the order was necessary and proper. In his dissent, Judge McMorrow disagreed with the majority's decision that a DNR order was in C.A.'s best interests because the precedential and statutory standards for making such a determination had not been met. In addition, the dissent pointed out that Illinois' Health Care and Surrogate Act does not supersede the provisions of the CAA and drew the Court's attention to the significance of the Amendments in determining whether to withhold medically indicated treatment.

20I. See supra text accompanying notes 49-50.

202. In other words, it would not make sense for the "virtually futile" exception to apply only when it is highly unlikely that treatment will prevent death in the near future, but for the "merely prolong dying" exception to apply any time the treating physician determines it is unlikely, i.e., less likely than not, that prognosis is for death in the more 
So interpreted, the regulations implementing the CAA indicate that a failure to provide treatment for an HIV-infected infant's lifethreatening conditions, ${ }^{203}$ at least while the infant's infection is asymptomatic or only mildly manifested, is unlikely to fall within an exception $^{204}$ permitting nontreatment and thus will constitute medical neglect. A conclusion that the CAA prohibit nontreatment of such infants, however, is not necessarily a conclusion that prohibition will effectively deter and address that behavior. Addressing the latter issue requires consideration of both the CAA's past effectiveness in addressing nontreatment in analogous situations and factual differences that may make the CAA more or less effective in responding to selective nontreatment of HIV-infected infants.

\section{B. Enforcement Predicaments}

As discussed above in Part III.B, an apparent lack of enforcement throws open to serious question the CAA's effectiveness in deterring and addressing selective nontreatment of disabled infants. ${ }^{205}$ Despite this lack of effective enforcement by state agencies, however, the Amendments and state legislation implementing their standards are currently the only legal avenues for addressing nontreatment choices made by a disabled infant's parents. ${ }^{206}$ As such, the Amendments conceivably could enable an effective response if parental nontreatment is

distant, as opposed to near, future. Bolstering this linkage between the exceptions is the Appendix's use of a futility standard in explaining the "merely prolong dying" exception: "The Department interprets the term 'merely prolong dying' as referring to situations where the prognosis is for death and ... further or alternative treatment would not alter the prognosis in an extension of time that would not render the treatment futile." 45 C.F.R. \& 1340 app. at 300 (1992).

203. The Appendix suggests that treatment is required for any condition that, while not itself immediately life-threatening, "significantly increases the risk of the onset of complications that may threaten the life of the infant." Id. at 298. By implication, failure to treat a condition that negatively affects the infant's development or well-being, but that does not increase the chance that a life-threatening complication will develop, would not constitute medical neglect as defined by the CAA.

204. Of course, a physician exercising reasonable medical judgment may determine that an infant infected with HIV is also "chronically and irreversibly comatose" or that treatment would "merely prolong dying" or would be "futile in terms of the survival of the infant" because the infected infant also suffers from another condition rendering the infant's prognosis for death in the near future. For example, withholding treatment from an HIV-infected infant whose head injuries in an automobile accident rendered her comatose or who is also anencephalic would fall within one of the exceptions and thus not constitute medical neglect. By contrast, my analysis focuses on an infant who is HIV positive and concurrently suffers a remediable life-threatening condition.

205. See supra notes $142-151$ and accompanying text.

206. Cf. Bowen v. American Hosp. Ass'n, 476 U.S. 610, 630 (1986) (plurality opinion) (noting that $\S 504$ is not called into question when parents refuse to consent to treatment). The ADA, while applicable to a far broader scope of actors than $\S 504$, presumably will not be read to extend to parental decisions regarding medical treatment for minor children. 
ever viewed as a problem of great public importance and claims a position of priority on the agendas of state child protection agencies. ${ }^{207}$

It is not in the context of parental decision-making, however, that the most problematic instances of nontreatment based on HIV infection are likely to occur. Rather, one can plausibly speculate that the parents of an HIV-infected infant may be less likely than the parents of an infant suffering another severe mental or physical disability to withhold their consent to life-saving treatment. A reason for parents' decisions to withhold treatment from a disabled newborn frequently cited during discussions of the Baby Doe controversy is the threat posed by the infant's continued life to the family's emotional and financial stability. ${ }^{208}$ For example, parents might justify the decision not to treat based on the need to protect the quality of life of other children in the family. In many cases involving an infant with HIV infection, by contrast, the family's living situation is already unstable, both financially and emotionally. ${ }^{209}$ In addition, the Medicaid program is likely to cover much of the costs of the infant's medical care. ${ }^{210}$ For these reasons, parents of HIV-infected infants may be less likely to feel that they have a great deal to lose by consenting to medical treatment that will sustain their infant's life. ${ }^{211}$

207. Little mention has been made recently regarding state agencies' responsibility to address medical neglect in the form of selective nontreatment. Congressional hearings conducted in 1991 on the Child Abuse Prevention and Treatment Act focused on the need to stem an increasing incidence of child abuse and neglect through the development of early intervention programs, but made no mention of the medical neglect provisions of the federal statute. See Child Abuse Prevention and Treatment in the 1990s: Keeping Old Promises, Meeting New Demands: Hearings Before the House Select Comm. on Children, Youth, and Families, 101st Cong., 2d Sess. 11-39 (1991).

208. See Jeff Lyon, Playing God in the Nursery 210 (1985) (discussing parental fear of financial and social constraints when choosing whether to permit medical treatment).

209. See supra Part II.B. for a description of the social context in which perinatal transmission of HIV most often occurs.

210. For a discussion of Medicaid coverage of health services for HIV-infected infants and children, see English, supra note 71, at 1553-57; see also Oleske, AIDS in Our Children, supra note 4, at 438-39 (discussing percentage of medical costs of HIVinfected children covered by Medicaid).

21I. Moreover, the parents of an infant infected with HIV may be less inclined culturally to allow an infant to die because it is less than "perfect." Undaunted by the risk of perinatal transmission of HIV, a substantial number of women who are infected with HIV neither refrain from becoming pregnant nor choose an abortion once pregnant. See Reproductive Behavior in HIV-Infected Women, supra note 48, at 1804 (citing finding that only 12 of $87 \mathrm{HIV}$-positive pregnant women and 11 of $101 \mathrm{HIV}$ negative pregnant women chose to abort their fetuses); Selwyn et al., supra note 48 , at 3568 (reporting study showing that 14 of 28 women with HIV chose to carry pregnancies to term). This willingness to become pregnant and carry to term an infant that faces a significant risk of infection with HIV may in some cases reflect a lack of access to family planning and abortion services, but may also bespeak both the value the women's culture and religion places on childbearing, see id. at 3571, and the women's perceived lack of other opportunities for achieving personal satisfaction. See Bayer, supra note 81, at 69-70 (explaining that for an HIV-positive woman, "[t]here is a 50-80 
While one can speculate that parental nontreatment decisions might be less likely to occur for infants with HIV than for infants with other disabilities, nontreatment decisions made by the state are more likely to occur. In the paradigmatic Baby Doe case, the parents decide to withhold treatment from their disabled newborn. ${ }^{212}$ By contrast, because a significant number of infants infected with HIV will become wards of the state, ${ }^{213}$ medical decisions for those infants will be made by the state or one of its agents. ${ }^{214}$ In addition, those parents who retain custody of their perinatally infected infant may not be the actual decision-makers for their infant's medical treatment; instead, the medical professionals treating the infant effectively may assume decisionmaking control.215 Again, as compared to the paradigmatic Baby Doe case, the danger of treating physicians assuming such control would

percent chance of having a healthy baby. From the perspective of an infected woman whose own life prospects are not good ... the chance of having a healthy baby might seem worth the risks entailed."). These influences may also come to bear on parents making medical treatment decisions for their perinatally infected infant.

For example, a survey conducted among IV drug using women who became pregnant yielded some interesting findings. Of the seropositive women who became pregnant $50 \%$ chose to terminate their pregnancy and $50 \%$ chose to continue pregnancy; of the seronegative women, $44 \%$ chose termination and $56 \%$ chose to carry to term. Among the reasons cited by seropositive women who chose to continue their pregnancy were religious beliefs, the overriding desire to have a child, family pressure to have a child, and reluctance to undergo abortion. Lack of access to abortion services was not a factor in this study, for all participants were offered the option of referral for abortion services covered in full by Medicaid. See Selwyn et al., supra note 48, at 3568, 3570 .

212. Cf. Bowen v. American Hosp. Ass'n, 476 U.S. 610, 633-34 (1986) (plurality opinion) (noting that all 49 cases of nontreatment cited by the Secretary of HHS as displaying a need for the promulgation of regulations under $\S 504$ involved instances where the infant's parents refused to consent to life-saving treatment).

213. See supra notes $66-75$ and accompanying text.

214. Throughout this discussion, references to decisions made by "the state" will include decisions made by agents of the state. See Vonner v. Department of Pub. Welfare, 273 So. 2d 252, 256 (La. 1973) ("It is the Department, not the foster parents, who has the legal custody of the child and, consequently, the right and responsibility to provide for the physical, mental, moral and emotional well-being of the child."). But cf. Jordy v. County of Humboldt, 14 Cal. Rptr. 2d 553, 558 (Cal. Ct. App. 1992) (holding that public agency is not liable for injury caused by foster parents' occasional negligence in day-to-day supervision of children). Agents of the state who might make medical treatment decisions for HIV-infected infants who are wards of the state include guardians, foster parents, operators of emergency shelters for medically fragile children, and representatives of child welfare agencies.

An example of a state agency's direct involvement can be found in In re C.A., 603 N.E.2d 1171 (Ill. App. Ct. 1992), appeal denied, 6 I0 N.E.2d 1264 (III. 1993), discussed supra note 200. In that case, Illinois's Department of Children and Family Services, which acted as the court-appointed guardian, filed a petition seeking authority to consent to the entry of a do not resuscitate order on the chart of a nine-month-old infant with HIV. By the time the trial court's order granting the petition was affirmed by the appellate court, the child was almost two years old. See id. at 1173.

215. See infra notes 244-246 and accompanying text for further discussion of the dangers of physician override in neonatal decision-making. 
appear to be magnified in the case of an HIV-infected infant whose parents are more likely to lack medical sophistication, be physically absent from the hospital, and receive less respect from the treating physicians. ${ }^{216}$

A decision not to provide life-saving treatment for an infant whose HIV infection remains asymptomatic or mildly symptomatic, when made either by the state for an infant in its custody 217 or by a treating physician who has assumed decision-making control for an infant, appears to fall within the scope of the Child Abuse Amendments' definition of medical neglect ${ }^{218}$ and thus should trigger the response provided for in the Amendments. Yet the already substantial barriers

216. Such a case is described in Guillemin \& Holmstrom, supra note 18, at 198-225. In this case, Darlene, a critically ill infant, was transferred from the NICU to the general pediatric nursery, where she died. Although Darlene was not infected with HIV, she shared many of the relevant characteristics of HIV-infected infants: plagued by a number of severe health problems, Darlene was born to a mother who was single, poor, and African-American. Darlene's transfer to the general pediatric nursery was a result of the treating physicians' decision, which was made without meaningful input from or intervention by the family or social workers. Although Darlene's mother, grandmother, and social workers were optimistic and wanted to keep Darlene in the NICU, the treating physicians' attitudes were negative regarding Darlene's prospects. The physicians experienced difficulty in communicating with both Darlene's mother (a single parent with learning disabilities) and her grandmother, perceiving the women as volatile and unresponsive to reasonable argument. See id. at 224. By failing to communicate with the family members, the physicians and staff effectively alienated them from participating in the decision-making process. The authors suggest this response may appropriately be regarded as a result of the unstable family situation attributed to Darlene. See id. at 223-24.

217. In the face of tightening budgetary constraints, a growing population of drugexposed infants, and negative societal attitudes towards persons infected with HIV, the danger that the state or its agent might decide not to provide life-saving treatment to an infant infected with HIV does not seem fanciful. The provision of medical care even for reasonably healthy children within the state's care is frequently sporadic and disorganized. See, e.g., David P. Schor \& Charles M. Abel, Back to Basics in Health Care for Foster Children, Children Today, May-June 1985, at I3-14 (pointing to lack of immunization of foster children as one manifestation of the neglect endemic to foster care systems); Suzanne Daley, Health Violations Cited at Child Group Homes, N.Y. Times, May 20, 1989, at 1 .

218. The Amendments define "child abuse and neglect" as meaning "the physical or mental injury, sexual abuse or exploitation, negligent treatment, or maltreatment of a child by a person who is responsible for the child's welfare . . ." 42 U.S.C. § $5106 \mathrm{~g}(4)$ (1988). The statute goes on to define "person who is responsible for the child's welfare" as including "any employee of a residential facility" and "any staff person providing out-of-home care." 42 U.S.C. \$ $5106 g(5)$. The latter definition makes clear that agents of the state may be guilty of child neglect, including medical neglect. Whether a physician's assuming effective, if not legal, control of medical decisionmaking for an infant makes the physician "a person responsible for the child's welfare" is a closer question. If it does not make the physician so responsible, then the CAA provide no deterrence for such behavior. Even if a physician who assumes control could be found guilty of child neglect, the CAA's standards are unlikely to be enforced against such behavior for reasons discussed in the text. 
to effective enforcement of the CAA's standards ${ }^{219}$ seem likely to prove even more acute in cases involving HIV-infected infants. In those cases, a state's child protective services agency may be both violator and enforcer. Depending on the state, a single agency or related agencies may be responsible for both responding to complaints of child abuse and neglect (including medical neglect as required by the CAA) and running the foster care system. For example, in New York State, the Department of Social Services is ultimately responsible both for dealing with complaints of child abuse and neglect and overseeing the care and placement of foster children. Thus, the same state agency may, on the one hand, either directly or through an agent decide not to provide an infant with needed medical treatment and, on the other hand, be responsible under the CAA for taking steps to prevent and address such practices. Moreover, because the state agency depends largely upon hospital personnel for reports of suspected medical neglect occurring within the hospital, 220 the agency may be unlikely to receive information about nontreatment decisions effectively made by treating physicians on the hospital's staff. The hospitals' failure to report seems probable in light of both the hierarchical structure of authority within neonatal intensive care units, ${ }^{221}$ which lessens the likelihood that caregivers such as neonatal nurses will break ranks even if they disagree with the decision to withhold treatment, and the generally negative reaction by neonatologists to the requirements imposed by the CAA. ${ }^{222}$

For all these reasons, the state-administered child welfare approach to selective nontreatment embodied in the Child Abuse Amendments, while applicable, seems unlikely to provide an adequate response to instances of selective nontreatment of an infant with HIV infection, whether the nontreatment decision is made by the infant's parents, by the state, or by a treating physician. Mindful of this conclusion, let us turn now to considering whether an antidiscrimination approach offers any greater promise.

219. See supra notes $143-150$ and accompanying text.

220. The Amendments call for the state to have in place procedures, among others, to provide for "prompt notification by individuals designated by and within appropriate health-care facilities of cases of suspected medical neglect." 42 U.S.C. $\S 5106 \mathrm{a}(\mathrm{b})(10)(\mathrm{B})(1988)$. In fourteen states, the state child protective services agencies explicitly abdicate authority to the hospital staff or infant care review committees to determine whether a child is illegally being denied treatment. See U.S. Comm'n on Civil Rights, supra note 151 , at $233-80$ app. c.

221. See supra note 150 and accompanying text.

222. See Kopelman et al., supra note 18, at 679 ("Most neonatologists who responded to our survey indicated that they thought the current federal regulations were a mistake."). The unlikeliness of full reporting is further supported by data showing that, from 1985 until the third quarter of 1988 , only seventeen state agencies received any reports of possible violations of the Amendments, and the total number of reports was only forty-one. See U.S. Comm'n on Civil Rights, supra note 151, at 233-80 app. c. 


\section{Applying the Lessons of History: The HIV-Infected Infant and DisabilitTy Discrimination LaW}

As discussed in Part 11I.A above, the Reagan administration's initial response to the death of Baby Doe was to issue regulations interpreting section 504 of the Rehabilitation Act to prohibit the withholding of life-saving medical treatment from a handicapped infant. ${ }^{223}$ Thus, the administration treated the problem as one of discrimination: Handicapped infants with life-threatening conditions were being treated differently from "otherwise normal" infants with lifethreatening conditions, and this difference in treatment constituted unjust and illegal discrimination.

While commentators debated the wisdom of addressing selective nontreatment as a discrimination problem, ${ }^{224}$ the Supreme Court ultimately declined to decide whether section 504 might ever apply to cases of selective nontreatment. Instead, the Court simply concluded that the requirements that the regulations imposed on health care facilities and state child welfare agencies were not justified by the administrative record. Thus, the Second Circuit's pronouncement in University Hospital that Congress did not intend section 504 to apply to selective nontreatment remains the primary authoritative judicial response to the question. In this Part, I argue that existing antidiscrimination law can be interpreted to advance the law's goal of eradicating disability discrimination in all public settings and still be construed with sensitivity to the complexity of medical decision-making. As so interpreted, antidiscrimination law provides an appropriate and potentially effective vehicle for addressing both selective nontreatment of infants with HIV infection and other discriminatory medical decisions.

\section{A. Section 504 and the ADA: Two Generations of Disability Discrimination Law}

The rationale employed by HHS in seeking to regulate selective nontreatment under section 504 also supports treating some cases of nontreatment of HIV-infected infants as illegal discrimination under either section 504 or the more recently enacted Americans with Disabilities Act (ADA). Both statutes prohibit discrimination on the basis of disability $^{225}$ and extend to discrimination based on asymptomatic HIV

223. See supra text accompanying notes $92-99$.

224. Compare Brown, supra note 88, at 251 (arguing that the $\S 504$ regulations' civil rights approach represented an overly simplistic response to selective nontreatment) with Martin H. Gerry, The Civil Rights of Handicapped Infants: An Oklahoma "Experiment," 1 Issues L. \& Med. 15, 42 (1985) (approving civil rights approach).

225. Congress did not intend the change in terminology from "handicap" in $\S 504$ to "disability" in the ADA to have any effect. Instead, the change simply reflects Congress' adoption of currently preferred terminology. See The Americans with Disabilities Act of 1989, S. Rep. No. 116, 101 st Cong., 1st Sess. 21 (1989); H. Rep. No. 
infection and AIDS. While section 504's application to HIV infection and AIDS has been by judicial construction, ${ }^{226}$ the ADA's legislative history indicates that Congress expressly contemplated coverage of HIV discrimination.227 Thus, HIV-infected infants clearly fall within the protective bounds of both section 504 and the ADA. ${ }^{228}$ Given this protection, the question that this Part must grapple with is whether and how the decision to withhold needed medical treatment from those infants is legislatively proscribed.

This Article focuses on resolving that question with respect to the ADA. ${ }^{229}$ Although many of the points made regarding the applicability of the ADA to selective nontreatment of HIV-infected infants could also be made with respect to section 504, the ADA's sweeping scope, explicitness of purpose, and legislative history ${ }^{230}$ lend support to its applicability that cannot be duplicated with respect to section 504. Un-

485, 101 st Cong., 2d Sess., pt. 2, at 50-51 \& pt. 3, at 26-27 (1990). In fact, the Rehabilitation Act Amendments of 1992 amended $\S 504$ to substitute the term "disability" for "handicap." See Pub. L. No. 102-569, \& 102(p)(32), 106 Stat. 4344, 4360 (1992) (codified at 29 U.S.C.A. $\$ 794$ (a) (West. Supp. 1993).

226. See, e.g., Harris v. Thigpen, 941 F.2d 1495, 1526 (11th Cir. 1991); Doe v. Attorney Gen. of United States, 941 F.2d 780, 790 (9th Cir. 1991); Severino v. North Fort Myers Fire Control Dist., 935 F.2d 1179, 1183 (11th Cir. 1991); Leckelt v. Board of Comm'rs, 909 F.2d 820, 825 (5th Cir. 1990); Martinez v. School Bd., 861 F.2d 1502, 1506 (1 Ith Cir. 1988). This line of cases flows from the Supreme Court's decision in School Bd. v. Arline, 480 U.S. 273 (1987), which held that $\S 504$ 's definition of "handicap" may extend to contagious diseases, in that case tuberculosis, because society regards people with such diseases as impaired.

227. Like the Rehabilitation Act's definition of "handicap," the ADA's definition of "disability" has three prongs: (1) actual impairment that substantially limits one or more major life activities; (2) a history of such impairment; or (3) being regarded as having such an impairment. See 42 U.S.C. $\$ 12102$ (2) (Supp. III 1991). The ADA's legislative history recognizes the first prong as including HIV infection. See H.R. Conf. Rep. No. 101-596, 101 st Cong., 2d Sess. 143 (1990), reprinted in H.R. Comm. on Educ. and Labor, 1 Legislative History of the Americans with Disabilities Act 120 (1990) [hereinafter Legislative History]. Moreover, even an infant whose own HIV status has not been confirmed, but who was born to an HIV-infected woman and whose blood contains HIV antibodies arguably suffers a disability under the definition's third prong if other persons believe the infant is infected. See 29 C.F.R. § 1630.2(1) app. (1992) (a person will be regarded as having an impairment if another person believes she has an impairment that she does not actually have). It is more questionable, however, whether an infant who is discriminated against hecause a $30 \%$ chance exists that he is HIV infected is protected by the ADA.

228. Infancy does not remove a person from the scope of $\S 504$ 's or the ADA's protection. See Bowen v. American Hosp. Ass'n, 476 U.S. 610, 624 (1986) (plurality opinion).

229. While this Article focuses on the applicability of the ADA, it relies frequently on judicial interpretations of analogous provisions of $\S 504$ as suggestions of how the courts are likely to interpret the ADA. Section 2201 of the ADA expressly states that "nothing in this chapter shall be construed to apply a lesser standard than the standards applied under title $V$ of the Rehabilitation Act of $1973 \ldots$. . or the regulations issued by Federal agencies pursuant to such title." 42 U.S.C. $\$ 12201$ (a).

230. See infra notes $235,237$. 
like section 504, which belongs to the first generation of disability rights legislation and whose inclusion in the Rehabilitation Act was marked by scant legislative history, ${ }^{231}$ the ADA represents the culmination of years of legislative efforts by disability rights advocates to achieve the enactment of comprehensive antidiscrimination legislation. ${ }^{232}$ Moreover, both tbe ADA's express terms and its legislative history illustrate the Act's mandate of eliminating all forms of discrimination against persons with disabilities in public life and ensuring their ability to participate fully in the opportunities and benefits of our society.

Congress' findings in enacting the ADA demonstrate both Congress' awareness of the scope of the problem of disability discrimination and its intent to adopt a correspondingly broad response to the problem. Specifically, Congress found that "historically, society has tended to isolate and segregate individuals with disabilities, and ... such forms of discrimination ... continue to be a serious and pervasive social problem," 233 that such discrimination persists in the critical area of "health services,"234 and that

individuals with disabilities are a discrete and insular minority who have been faced with restrictions and limitations, subjected to a history of purposeful unequal treatment, and relegated to a position of political powerlessness in our society, based on characteristics that are beyond the control of such individuals and resulting from stereotypic assumptions not truly indicative of the individual ability of such individuals to participate in, and contribute to, society. ${ }^{235}$

231. See Richard K. Scotch, From Good Will to Civil Rights: Transforming Federal Disability Policy 49-59 (1984) (discussing the evolution and passage of the Rehabilitation Act and $\S 504$ ).

232. In the 1970 s and 1980 s, a number of federal laws advanced specific goals of disability rights advocates and laid the foundation for the ADA. See, e.g., Individuals with Disabilities Education Act, 20 U.S.C. §§ 1232, 1400-1485 (1988) (originally enacted as Education for All Handicapped Children Act in 1975) (mandating a "free appropriate public education" for all children with disabilities in the least restrictive environment); Fair Housing Act Amendments of 1988, 28 U.S.C. §§ 2341, 2342 (1988) (prohibiting discrimination against persons with disabilities in selling and renting of public and private housing); Developmental Disabilities Assistance and Bill of Rights Act, 42 U.S.C. $\$ \$ 6000-6081$ (1988) (enacted 1975) (establishing, inter alia, a system of state protection and advocacy organizations for persons with developmental disabilities); Air Carrier Access Act, 49 U.S.C. $\S \S 1301,1374$ (1990) (enacted 1986) (prohibiting discrimination by air carriers against persons with disabilities). See generally Jane West, The Social and Policy Context of the Act in The Americans with Disabilities Act: From Policy to Practice 15-19 (1991).

233. 42 U.S.C. $\S 12101$ (a)(2).

234. 42 U.S.C. $\$ 12101(\mathrm{a})(3)$.

235. 42 U.S.C. $\S 12101(a)(7)$. The legislative history notes that "discrimination against persons with disabilities often results from false presumptions, generalizations, misperceptions, patronizing attitudes, ignorance, irrational fears, and pernicious mythologies." H.R. Rep. No. 485, 101 st Cong., 2d Sess., pt. 2, at 30 (1990), reprinted in Legislative History, supra note 227, at 302. 
Based on these and other findings, Congress announced the Act's purpose as "provid[ing] a clear and comprehensive national mandate for the elimination of discrimination against individuals with disabilities."236 A national solution was deemed necessary in light of the failure of existing federal and state laws to address adequately the discrimination faced by disabled persons. ${ }^{237}$ Thus, Congress consciously chose to pursue a national solution by adopting a broad, sweeping legislative approach rather than limiting the legislation to discrete types of discrimination. ${ }^{238}$ ln so doing, Congress expressly acknowledged the comprehensive impact that it intended the ADA to have.

Another reason for focusing analysis on the ADA is that it prohibits discrimination by a broader range of actors than does section 504, which applies only to programs receiving federal financial assistance. ${ }^{239}$ By contrast, the ADA's mandate reaches virtually all economic actors that offer employment, goods, or services to the public. Particularly important for this Article's analysis is the ADA's coverage of public entities in Title II and public accommodations in Title IlI. Because a

236. 42 U.S.C. $\S 12101(\mathrm{~b})(1)$.

237. See H.R. Rep. No. 485, 101st Cong., 2d Sess., pt. 2, at 29 (1990), reprinted in Legislative History, supra note 227, at $304,320$.

238. The stated purpose of the Rehabilitation Act has evolved and broadened over time. From its focus on "vocational rehabilitation and independent living" from the time of the Act's passage through the mid-1980s, see 29 U.S.C. $§ 701$ (1988) ("The purpose of this chapter is to develop and implement, through research, training, services, and the guarantee of equal opportunity, comprehensive and coordinated programs of vocational rehabilitation and independent living."), Congress has broadened the Act's purpose to address broader issues of empowerment of individuals with disabilities. See 29 U.S.C.A. $\$ 701$ (b) (West Supp. 1993) ("The purposes of this chapter are-(1) to empower individuals with disabilities to maximize employment, economic self-sufficiency, independence, and inclusion and integration into society, ... . and (2) to ensure that the Federal Government plays a leadership role in promoting the employment of individuals with disabilities ...."). Even this broadened statement of purpose, however, is less comprehensive than the ADA's.

239. See 29 U.S.C. $\$ 794$. Of course, extensive federal government funding of social services and health care programs means that $\$ 504$ may in fact cover many actors in these fields. See Gittler \& Rennert, supra note 78, at 1343-44 nn.149-51 (listing health, child welfare, and other social service programs receiving federal funds). For example, a hospital that receives Medicaid or Medicare reimbursement qualifies as "receiving federal financial assistance" within the meaning of $\S 504$ and is thus bound by its requirements. See Glanz v. Vernick, 756 F. Supp. 632, 636 (D. Mass. 1991). In addition, the court in Glanz found that a clinic may be held liable under the doctrine of respondeat superior for the acts of an employee physician. See id. at 636-37. Moreover, the definition of "program or activity" for purposes of $\S 504$ (added in 1988) suggests that even an individual physician could be liable for violating $\$ 504$ if she receives federal funds. See 29 U.S.C.A. § 794(b) (defining "program or activity" in pertinent part as "all of the operations of . . . [a] partnership, . . . or an entire sole proprietorship, ... . which is principally engaged in the business of providing . . . health care").

Nonetheless, §504's limitation to federally funded programs sets up a potential roadblock to coverage in individual cases, a roadblock that the ADA never creates. 
"public entity" includes "any department, agency . . . or other instrumentality of a State," 240 state child welfare agencies responsible for infant wards of the state are subject to the ADA. And because "public accommodations" include hospitals and the professional offices of health care providers, ${ }^{241}$ a hospital or physician treating an infant infected with HIV is subject to the ADA.

Of course, in most cases an infant's parents make decisions regarding their baby's medical treatment, and neither section 504 nor the ADA extends to such quintessentially private, parental decision-making. ${ }^{242}$ Nonetheless, because many infants infected with HIV become wards of the state, ${ }^{243}$ the ADA's public entity provisions may apply to treatment decisions made for those infants, whether made directly by a state agency or by foster parents or other agents of the state. Furthermore, the ADA's public accommodations provisions may be triggered when, despite parental retention of legal responsibility for medical decision-making, the infant's treating physician effectively makes medical decisions for the infant.

As Justice White recognized in his dissent from the Bowen plurality, because physicians participate in formulating parental treatment decisions, "discrimination against a handicapped infant may assume gnises other than the outright refusal to treat once parental consent has been given."244 In some instances, moreover, physicians may go beyond influencing parental decisions to assume the role of actual decisionmaker. This usurpation of decision-making authority seems likely to occur not only when the parents willingly abdicate decision-making authority to treating physicians, ${ }^{245}$ but also when the parents are frequently absent from the hospital or when the treating physicians hold the parents' decision-making or caregiving capacity in low regard. ${ }^{246}$

\section{B. Responding to the Medical Complexity Argument}

Although neither the ADA nor its legislative history specifically ad-

240. 42 U.S.C. $\S 12131(1)$.

241. See 42 U.S.C. $\$ 12181(7)(F)$. Like other private entities, a doctor's office and a hospital are considered public accommodations if their operations affect commerce. See id.

242. Cf. Bowen v. American Hosp. Ass'n, 476 U.S. 610, 647 (1986) (plurality opinion) (finding no role for government in parental decisions).

243. See supra note 67 and accompanying text.

244. Bowen, 476 U.S. at 659 (White, J., dissenting). Cf. Johnson v. Thompson, 971 F.2d 1487, 1492 (10th Cir. 1992) (dictum) (accepting plaintiffs' arguments that if the treating physicians' action "rendered parental consent a sham, such 'consent' cannot be considered an intervening cause that makes section 504 inapplicable").

245. Cf. Weir, supra note 2, at 21 (asserting that infanticide may occur by "parents abandoning a premature or defective infant to the medical staff in an NICU, with decision-making about the infant's life or death being left to the physicians").

246. See, e.g., Guillemin \& Holmstrom, supra note 18, at 198-225 (describing appropriation of decision-making power by medical personnel when patient's family is perceived as incompetent and unresponsive). 
dresses the legislation's applicability to medical treatment decisions, simply reading the ADA's language suggests that its facial prohibitions on discriminatory treatment apply to medical decision-makers who fail to treat certain infants because of their HIV status. Congress recognized the persistence of discrimination against persons with disabilities in health settings ${ }^{247}$ and expressly extended the Act's mandate of eliminating disability discrimination to state agencies, hospitals, and physicians. ${ }^{248}$ Accordingly, the ADA's prohibitions ${ }^{249}$ would seem to proscribe the failure by such actors to provide medical treatment to an HIV-infected infant when the same treatment would be provided to an uninfected infant. The factual hypotheticals posed by the JAMA survey appear to demonstrate that such situations may exist. While $97 \%$ of respondents in the survey indicated they would provide open-heart surgery to an infant with a ventriculoseptal defect and no other concomitant conditions, only $42 \%$ would provide the surgery for an infant with a ventriculoseptal defect and HIV infection. ${ }^{250}$ Approximately half of the respondents would withhold treatment based on the infant's HIV infection, a seemingly clearcut example of discrimination based on disability. Not only does this situation fall within the ADA's express terms, but reading the ADA to prohibit such discriminatory medical decisionmaking also appears ethically sound. ${ }^{251}$ Just as an infant with a ventriculoseptal defect should not be denied open heart surgery because she is African-American or Jewish, so too she should not be denied the needed surgical treatment because she is blind or HIV infected.

Despite the facial appeal of this argument, which mirrors the argument made by the Reagan administration in promulgating its Baby Doe regulations under section 504, the argument faces several objections. First, one can argue that although the ADA's prohibitions of disability discrimination are by their terms sufficiently broad to encompass medical decisions made by doctors, hospitals, state social workers, or foster parents for HIV-infected infants, the statute's legislative history con-

247. See 42 U.S.C. $\S 12101$ (a)(3).

248. See 42 U.S.C. $\S 12181(7)(f)$.

249. Under Title II of the ADA, "no qualified individual with a disability shall, by reason of such disability, be excluded from participation in or be denied the benefits of the services, programs, or activities of a public entity, or be subjected to discrimination by any such entity." 42 U.S.C. $\$ 12132$. Title III states the general rule applicable to public accommodations as follows: "No individual shall be discriminated against on the basis of disability in the full and equal enjoyment of the goods, services, facilities, privileges, advantages, or accommodations of any place of public accommodation by any person who owns, leases (or leases to), or operates a place of public accommodation." 42 U.S.C. $\$ 12182(a)$.

250. See Levin et al., supra note 5 , at 2978.

251. The ethical principle of nondiscrimination demands that in the allocation of benefits (in this case, open-heart surgery) "no one be denied benefits based on characteristics irrelevant to the purposes of the distribution in question" (in this case, preservation of life through surgical correction of a heart defect). Arras, supra note 92, at 97. 
tains no indication that Congress ever specifically contemplated applying the statute to those decisions. Thus, the ADA and its legislative history by themselves do not clearly indicate whether or how the ADA's antidiscrimination mandate should apply to medical treatment decisions. ${ }^{252}$

Perhaps a more fundamental objection, though, is that antidiscrimination law simply is not an appropriate mechanism for regulating the complex process of medical decision-making. To wit, antidiscrimination law and the nondiscrimination principle of justice must take as their premise that the persons seeking to receive benefits are similarly situated except for the trait that prompts the discrimination; ${ }^{253}$ in other words, no distinction legally or morally relevant to the distribution of the benefit in question exists between the persons. According to critics of the section 504 Baby Doe regulations, however, this premise is faulty in many cases involving disabled newborns. While it may be logically and morally correct to say that, except for having Down syndrome, Baby Doe was similarly situated to an infant of normal intelligence with an esophageal blockage and therefore should not have been denied the benefit of treatment, it makes no sense to apply this line of reasoning to an infant whose need for medical treatment is generated by a condition that, by definition, is never present in nondisabled infants. ${ }^{254}$ Stated more generally, the argument is that the nondiscrimination principle is logically inapplicable to a disabled patient who seeks medical treatment somehow related to her disability because nondisabled but otherwise similarly situated patients do not exist.

252. Accord Lawrence O. Gostin, The Americans with Disabilities Act and the U.S. Health System, Health Affairs, Fall 1992, at 248, 251 ("The ADA does not completely clarify the distinction between the genuine exercise of clinical judgment and unlawful discrimination."); see also Wendy E. Parmet, Discrimination and Disability: The Challenges of the ADA, $18 \mathrm{~L}$. Med. \& Health Care 331, 339 (1990) (noting that ADA provides little guidance for deregulation of medical decision-making).

Three possible interpretations of the ADA in the context of medical decisionmaking are evaluated infra Part VI.B.1-3.

253. This premise is reflected in the "otherwise qualified" language of $\S 504$ and in Title II of the ADA's limitation to "qualified individual[s]," 42 U.S.C. $\$ 12132$, for a failure to qualify for the benefits at issue would be a legally and morally relevant distinction. Although Title III's protection against discrimination by public accommodations is not limited to "qualified" individuals (probably because one does not normally think of needing to be "qualified" to eat at a restaurant, visit a museum, or go to a doctor's office), the ability of public accommodations to impose some types of eligibility criteria (e.g., ability and willingness to pay) is accepted as long as the criteria do not screen or tend to screen out individuals with disabilities. See id. §12I82(a), (b)(2)(A)(i).

254. See Arras, supra note 92, at I02. An infant needing surgery to correct the myelomeningocele, or opening of the spine, associated with spina bifida exemplifies this situation. Because nondisabled infants never have a myelomeningocele, an infant with spina bifida cannot be similarly situated to a nondisabled infant with respect to its need for corrective surgery. 
What 1 shall call the "medical complexity argument" was one of the medical profession's primary objections to HHS's section 504 regulations, and the Second Circuit accepted this argument in finding section 504 inapplicable to medical decision-making for disabled infants:

[S]ection 504 prohibits discrimination against a handicapped individual only where the individual's handicap is unrelated to, and thus improper to consideration of, the services in question. As defendants here point out, however, where medical treatment is at issue, it is typically the handicap itself that gives rise to, or at least contributes to, the need for services. Defendants thus argue, and with some force, that the "otherwise qualified" criterion of section 504 cannot be meaningfully applied to a medical treatment decision. ...

Second, in arguing that Baby Jane may have been "subjected to discrimination" the government has taken an oversimplified view of the medical decisionmaking process. Where the handicapping condition is related to the condition(s) to be treated, it will rarely, if ever, be possible to say with certainty that a particular decision was "discriminatory". ${ }^{255}$

Acknowledging the force carried by the argument that the complexity of medical decision-making prevents the meaningful application of the ADA to treatment decisions for persons with disabilities generally and, more specifically, for infants infected with HIV, could lead us to adopt one of at least three possible responses. First, we could conclude that the ADA is simply inapplicable to medical decision-making for the reasons stated by the Second Circuit. Second, we could read the ADA to apply to medical decision-making only in those limited instances when the condition requiring treatment is unrelated to the patient's disabling condition. Finally, we could conclude that the ADA applies to all medical decision-making, but interpret its antidiscrimination mandates as prohibiting nontreatment based on the mere existence of disability, while allowing consideration of the medical effects of disability. Although the former two responses both find some support in case law interpreting section 504, this Article asserts that the third response is preferable because it would allow comprehensive implementation of the ADA's sweeping mandate against disability discrimination in a fashion concordant with existing ethical standards for decision-making for disabled infants and competent patients.

1. ADA Inapplicable to Medical Treatment Decisions.-The cleanest and easiest way to respond to the argument that the complex nature of medical decision-making places it outside the ADA's protective realm would be to accept the argument, much as the Second Circuit accepted the same argument regarding the applicability of section 504. Adopting this approach would not render the ADA's reference to discrimina- 
tion in the "health services" entirely meaningless, for the Act could still be interpreted as ensuring physical access to facilities where health services are provided ${ }^{256}$ and prohibiting providers from turning away a patient based on disability, at least when the patient seeks treatment unrelated to his disability. ${ }^{257}$

In addition to the argument that applying a nondiscrimination standard to medical decision-making is simply too difficult, this approach arguably is supported by Congress' failure to indicate its intent that the ADA apply to individual decisions regarding medical treatment. The legislative history contains no evidence that Congress specifically contemplated such an application, and it can be argued that congressional intent to intrude on the realm of medical decision-making should not be inferred in that absence. ${ }^{258}$

This argument, however, founders when we consider making the same argument with respect to other antidiscrimination legislation. It seems apparent that a child welfare agency that has a pattern of deciding to immunize white children under its care but not African-American children could not successfully defend its actions based on the lack of reference to discrimination in medical decision-making in the legislative history of the Civil Rights Act of 1964.259 Moreover, in the ADA's

256. See Parmet, supra note 252, at 339.

257. For a discussion of how the ADA's prohibition against discrimination in health services operates in the context of HIV-infected women and children seeking access to health services, see Gittler \& Rennert, supra note 78, at 1364-74. The legislative history's examples of prohibited discrimination in health services deal only with discrimination based on a disability unrelated to that service. For example, a doctor specializing in burns cannot refuse to accept a burn victim because that patient is also deaf, and a drug clinic cannot refuse treatment to a drug addict simply because the patient has HIV. See H.R. Rep. No. 485, 101st Cong., 2d Sess., pt. 2, at 30 (1990), reprinted in Legislative History, supra note 227 , at $378-79$. The legislative history does not address a patient's access to treatment for the disability itself, nor does it address the health care provider's decision-making processes regarding what treatment options to recommend once the provider has established a relationship with the patient. It is the latter process on which this Article's analysis focuses.

258. Cf. University Hosp., 729 F.2d at 160 ("[T] treatment decisions involving defective newborn infants strikes a telling blow to the government's position" that section 504 applies to such decisions.). The Second Circuit also cited prior congressional enactments reflecting a federal policy against the involvement of federal personnel in medical treatment decisions and concluded that a reversal of such a policy should not be inferred without clear evidence of congressional intent. See id. Since 1984, however, a number of enactments, while not placing decision-making authority in federal hands, have evidenced growing federal influence over medical decision-making. See, e.g., Rust v. Sullivan, 111 S. Ct. 1759 (1991) (upholding regulations prohibiting federally funded family planning clinics from engaging in counseling and referrals for abortion).

259. Cf. University Hosp., 729 F.2d at 162 (Winter, J., dissenting) (analogizing handicap discrimination to racial discrimination based on legislative history of § 504). Although the majority opinion in University Hospital rejected Judge Winter's racial analogy, it did so not because of a difference between the legislative histories of the Civil Rights Act and $\S 504$, but because it found the analogy to break down in the face of the 
sweeping language and announced goal of providing "a clear and comprehensive national mandate for the elimination of discrimination against individuals with disabilities," there is clear evidence that Congress must have anticipated that the ADA's broad mandate would inevitably reach beyond the examples of discrimination specifically described in the legislative history. 260

Perhaps the strongest objection to simply finding the ADA inapplicable to medical treatment decisions is that such an approach goes too far. That approach would leave the "easy cases," those to which the medical complexity argument is factually inapplicable, unaddressed. For example, decisions made at a state-run children's group home to immunize all sighted children of normal intelligence but not blind children or mentally retarded children would not violate the ADA, ${ }^{261}$ even though these decisions clearly seem to embody the type of disability discrimination that the ADA intends to prohibit. This outcome in easy cases of discrimination is inconsistent with the ADA's philosophy and suggests we should not allow the medical complexity characterizing hard cases to immunize all medical treatment decisions from scrutiny under the ADA. ${ }^{262}$

2. ADA Applies under a Relatedness Standard.-One way to acknowledge the force of the medical complexity argument without simply surrendering the ADA's protections with respect to all medical treatment decisions would be to read the ADA as applying only to those medical treatment decisions in which the condition to be treated is unrelated to the patient's disabling condition. This approach would be consistent with University Hospital's conclusion that antidiscrimination law is inapplicable when "the handicap itself . . . gives rise to, or at least contributes to, the need for [medical] services."263 A few courts considering

relationship between handicap and the condition needing medical treatment. See id. at 157. In other words, the medical complexity argument holds particular power in the context of disability discrimination, as opposed to racial discrimination.

260. 42 U.S.C. $\$ 12101$ (b)(1) (emphasis added). Of course, a dimmer view of congressional awareness and intent could also be taken. Professor Wendy Parmet argues that the ADA is "extraordinarily unclear about its impact on medical decisionmaking" and that the statute's failure to specify its impact on treatment decisions "bespeaks a vision that sees disability as both limited and discrete." In light of the statutory ambiguities regarding how the ADA applies to health services, Parmet predicts that the judiciary will construe the ADA to have a narrower reach than initially appears from its broad language. See Parmet, supra note 252, at 339.

261. Of course, such a failure might constitute medical neglect under the Child Abuse Amendments of 1984, but the difficulty of enforcing the Amendments' standards has been discussed supra text accompanying notes 143-150. A failure to provide routine immunizations is in fact an example cited in articles discussing weaknesses in the foster care medical system. See supra note 217.

262. Accord Gostin, supra note 252, at 251 ("The physician's exercise of clinical judgment cannot render all treatment refusals or referrals immune from review if there is evidence that they were motivated by prejudice or irrational fear.").

263. University Hosp., 729 F.2d at 156. 
section 504 subsequently to University Hospital have recognized this approach as potentially viable, ${ }^{264}$ although none has found it factually applicable. For example, in Gerben v. Holsclaw ${ }^{265}$ the court considered whether an infant with cystic fibrosis was subjected to a painful and aggressive treatment plan because her incompetence to object effectively rendered her handicapped. Using a relatedness standard, the court found that the treatment for cystic fibrosis was unrelated to the infant's condition of being a nonconscious adult, but rejected the section 504 challenge because infancy is not a "handicap" under section $504 .{ }^{266}$

If we adopted this approach to interpreting the ADA's applicability to medical treatment decisions, the threshold question would of course be whether the condition for which the patient needs treatment is related to or results from the patient's disability. In many cases this question would be easy to answer. The decision whether to perform surgery to correct the myelomeningocele of an infant with spina bifida would not be covered by the ADA because the myelomeningocele is itself a manifestation of the infant's disabling condition. By contrast, the decision whether to perform surgery to correct the duodenal atresia of an infant with HIV infection, as hypothesized by the JAMA survey, would be covered by the ADA because medical research has not shown duodenal atresia to be related to or caused by perinatal HIV infection. This approach would lead to satisfactory results, at least with respect to the applicability of the ADA, in cases like these where the relationship, or lack thereof, between the disabling condition and the condition for which treatment is required is clear.

In other cases, however, the line between medical conditions related to a disability and those unrelated may be harder to draw. The difficulty in drawing that line is particularly acute when the disabling condition is HIV infection because medical science is still in the early stages of exploring the virus's different effects in both adult and pediatric populations. As a result, the issue of causality and hence relatedness between HIV infection and a condition needing treatment may be unclear. For example, because all children are susceptible to many communicable diseases, immunizations are routinely recommended. Children with HIV infection, however, by reason of their compromised immune system, are both particularly susceptible to diseases and potentially susceptible to being harmed by the altered viruses contained in an immunization. ${ }^{267}$ This raises the issue whether the HIV-infected child's need for immunization is "related to" his HIV infection so that

264. See Johnson v. Thompson, 971 F.2d 1487, 1494 n.3 (10th Cir. 1992); Gerben v. Holsclaw, 692 F. Supp. 557, 562-64 (E.D. Pa. 1988); see also Bowen v. American Hosp. Ass'n, 476 U.S. 610, 655 (1986) (White, J., dissenting).

265. 692 F. Supp. 557 (E.D. Pa. 1988).

266. See id. at 562-63.

267. Cf. Mendez \& Jule, supra note 52, at 645 ("With the exception of oral polio 
the ADA is inapplicable to a decision whether and how to immunize the child.

Moreover, at least with respect to treatment decisions for patients infected with HIV, the "related to the disability" approach fails to encompass the full range of medical complexity that HIV infection introduces into treatment decisions. This complexity results from the very nature of HIV disease, which causes harm by so weakening a person's immune system that other opportunistic infections are able to flourish. This heightened vulnerability to other infections means that consideration of a patient's HIV infection may need to be part of the treatment decision equation even when the condition requiring treatment is itself unrelated to the patient's HIV status. For example, if a child with HIV infection suffers a perforation of her eardrum unrelated to her infection, the relatively greater dangers posed by nosocomial infection from surgery to a patient with HIV infection may be a medically justified consideration in deciding whether to treat the condition by antibiotics or by surgery. ${ }^{268}$ Although the perforation is unrelated to the patient's disabling condition, the disability may by necessity be implicated in making a medically sound treatment decision.

Thus, while it offers a superficially attractive response to the medical complexity argument, the "related to the disability" standard for assessing the ADA's applicability to medical treatment decisions ultimately proves less than satisfactory. Rather than providing a clearcut standard, this approach both creates difficult line-drawing problems regarding relatedness in some situations and fails in other situations to respond adequately to the medical complexity argument.

3. ADA Prohibits the Use of Disability as a Proxy: The Medical Effects Approach.-A third possible response to the medical complexity argument, and the response advocated by this Article, would be to read the $\mathrm{ADA}$ as applying to all medical decision-making, but to focus attention on what "discrimination based on disability" properly means in the context of medical treatment decisions. In other words, what actions by a person deciding on medical treatment for a patient with a disability constitute illegal discrimination against that patient on the basis of her disability? I will argue that such an approach represents an improvement over the relatedness standard discussed above, because a standard can be formulated to answer the foregoing question that deals adequately both with those cases for which the relatedness standard produces satisfactory results and those cases where that standard falls short.

If the hypothetical cases discussed above are reconsidered, focus-

vaccine, for which a safe and effective ... vaccine alternative is available, the vaccines given to HIV-exposed infants are the same as those used in other children.").

268. See, e.g., Glanz v. Vernick, 756 F. Supp. 632, 634 (D. Mass. 1991) [hereinafter Glanz $I I]$ (doctor refused to perform ear surgery on AIDS-infected patient alleging that surgery would pose significant health risks). 
ing not on relatedness between the disability and the condition needing treatment, but on permissible factors for the decision-maker to consider, a pattern emerges. A state child welfare agency cannot consider a child's blindness in determining whether to immunize the child. While it is true that blindness is unrelated to the need for immunization, the ethical relevance of this lack of relatedness is that the child's blindness has no medical effects relevant to determining what the child's prognosis is or what treatment is in the child's best interests. The blindness is simply irrelevant to making an ethical medical decision.

Consider again a state-run group home deciding whether to immunize a child infected with HIV. While arguments can be made both for and against finding relatedness between the child's need for immunization and her infection, what is indisputable is that in this case the child's disability may have a medical effect-her greater susceptibility to infection-that is highly relevant to deciding whether immunization is in her best interest and, if so, what form of immunization and possible followup is indicated. Thus, though its relatedness to a child's need for immunization is debatable, the HIV infection is relevant to making an ethical medical decision. Finally, the decision whether to treat the perforated eardrum by antibiotics or by surgery can be analyzed the same way. Although the child's HIV infection is causally unrelated to the condition needing treatment, again the infection produces a medical effect that may be highly relevant to the treatment decision.

The contours of an alternative approach to interpreting the ADA in the context of medical treatment decision-making thus begin to emerge: While the ADA should prohibit treating a patient with a disability differently based simply on the disability's existence (for example, the failure to immunize a blind child), the ADA should permit consideration of any relevant medical effects a disability produces in deciding whether and how to treat a related or unrelated condition. This third approach, which I shall call the "medical effects approach," seeks to identify illegitimate discrimination by distinguishing between decisions made based on the mere existence of disability and those made after considering the medical effects of disability.

For example, to return to the JAMA survey, would the decision not to provide life-saving corrective surgery to an infant infected with HIV when the surgery would be provided to an uninfected infant constitute prohibited discrimination based on disability? The answer depends on whether the HIV infection has produced in this infant medical effects relevant to deciding whether to perform surgery. Answering this question requires not simply assessing "relatedness," but pursuing a number of factual inquiries: How compromised has this infant's immune system become as a result of the infection? Is there alternative nonsurgical treatment for the infant's condition? Has the infant's infection yet manifested itself in a way that provides reliable clues as to the 
infant's life expectancy, so that the benefits of achieving that life expectancy can be weighed against the invasiveness and risks of surgery? Or, by contrast, does the infection remain asymptomatic so that no reliable prediction of the infection's clinical course or life expectancy can be made? This line of reasoning suggests that the decision not to perform corrective surgery for an HIV-infected infant may in some instances be legally and ethically justifiable. ${ }^{269}$

Although the courts have not articulated a distinction between decisions based on the existence of disability and decisions based on consideration of the medical effects of disability, a few courts have engaged in similar lines of reasoning. In Glanz $v$. Vernick,, 270 the court considered a section 504 action alleging that the hospital and physician had discriminatorily refused to perform ear surgery on a patient with HIV infection. The defendants moved for summary judgment, ${ }^{271}$ arguing, among other things, that the patient was not "otherwise qualified" for the surgery because of his HIV infection. The court reasoned that section 504's "otherwise qualified" limitation allowed the defendants to consider the patient's infection in terms of the risks that infection posed both to the patient himself and to the physician, but cautioned that determining the patient's qualification for surgery required "an individualized inquiry and appropriate findings of fact."272 Finding that the plaintiff had produced facts supporting the conclusion that the patient was "otherwise qualified" for surgery, the court denied the motion for summary judgment. ${ }^{273}$

269. This conclusion, however, makes the results of the JAMA survey no less troubling, for the survey described only limited facts regarding its hypothetical cases (e.g., the concurrence of HIV infection and duodenal atresia). As a result, respondents lacked sufficient information regarding an individual infant's condition and prognosis to engage in the analysis described in the text. Thus, it would appear that many respondents used the simple fact of HIV infection as a proxy for such individualized assessment.

270. 756 F. Supp. 632 (D. Mass. 1991).

271. Prior to moving for summary judgment, defendants had moved to dismiss, arguing that under University Hospital $\$ 504$ did not protect a plaintiff claiming discrimination in individual medical treatment decisions. After quoting with approval Judge Winter's dissent in University Hospital, the court distinguished the case before it from University Hospital as not involving an infant and not requiring the court to override parental authority. See Glanz v. Vernick, 750 F. Supp. 39, 45-46 (D. Mass. 1990) [hereinafter Glanz I].

272. Glanz II, 756 F. Supp. at 638.

273. Although Glanz II supports the proposition that applying antidiscrimination law to medical treatment decisions requires an individualized assessment of the patient's condition, I think the court interpreted the "otherwise qualified" limitation erroneously by suggesting that the patient might not be otherwise qualified for surgery because of risks posed by the surgery to the patient himself. Not only is this suggestion inconsistent with the judicial origin of the "direct threat" standard, see School Bd. v. Arline, 480 U.S. 273 (1987), it is also inconsistent with the principle of informed consent, which leaves the decision regarding the acceptability of medical or surgical risk to a competent patient. In other words, the risks of infection might be weighed by a 
Although the court in Glanz did not distinguish a refusal to perform surgery based on the mere existence of HIV infection from a refusal based on consideration of the infection's effects, it did recognize that those effects (i.e., the patient's susceptibility to infection and the possibility of transmission during surgery) should be individually assessed as part of determining whether the patient had been the victim of unjustifiable discrimination. ${ }^{274}$ This focus on the individualized assessment of a disability's effects also appears in Garrity v. Gallen, ${ }^{275}$ a case involving the provision of rehabilitative services to mentally retarded persons. ${ }^{276}$ In that case the court found that state officials had violated section 504 by making placements and providing services "based not on an individual assessment of the abilities and potentials of each resident but on the generalized assumption that certain groups of people ... are unable to benefit from certain activities and services."277 The court found such "blanket discrimination" inconsistent with section 504's fundamental premise of "the need for individualized treatment."278

physician in recommending a certain treatment option, but the decision regarding which treatment option to pursue ultimately belongs to a competent patient.

274. One could suggest that, based on this analysis, the medical effects approach is actually more consistent with the "otherwise qualified" standard employed by $\S 504$ than with the "individual with a disability" standard, which requires greater efforts towards accommodation of the effects of a disability, employed in the employment and public entity provisions of the ADA. The effect of this distinction, however, becomes difficult to grasp in the context of medical decision-making. Consider again the example of the HIV-infected child with a perforated eardrum, and assume that her immune system is severely compromised. This medical effect of her infection may make the decision-maker more likely to conclude that, because of the dangers of infection resulting from surgery, treatment with antibiotics is in the child's best interests. One way to describe the situation in antidiscrimination law jargon is to conclude that the child was not "otherwise qualified" for surgical treatment. It seems equally accurate, however, to say that the effects of the child's disability (i.e., her heightened susceptibility to infection) could not be "reasonably accommodated." Even if one assumes that by hypersterilizing surgical conditions and providing aggressive postoperative infection control measures the susceptibility to infection could be "accommodated," I would argue that this process of analysis regarding possible accommodations is subsumed within a full assessment of the child's condition and prognosis to determine what treatment is in her best interests.

275. 522 F. Supp. 171 (D.N.H. 1981).

276. Although Garrity did not involve medical treatment, decisions regarding rehabilitative services for developmentally or mentally disabled individuals are in many ways analogous to decisions regarding medical treatment. In both instances, the disabled person requires services for a condition that is frequently, although not invariably, related to her disabling condition. In both cases, the effects of the disability must be considered to determine what services will be of the greatest benefit to the person.

277. 522 F. Supp. at 214.

278. Id. at 213-14. The court also found a $\$ 504$ violation in the defendants' providing some, but not others, of the school's residents with individual service plans. Which residents would receive a plan was decided not on the basis of any kind of individualized assessment process, but on the basis of which buildings the residents 
What Glanz, Garrity, and the medical effects approach all find objectionable is a decision-maker's reliance on the mere existence of disability as a proxy for an individualized, factual assessment of the disabled person's condition. That kind of proxy decision-making in the context of medical treatment should ordinarily be seen as prohibited by the $A D A$, for it is likely to reflect generalized assumptions and prejudices $^{279}$ about disability that Congress sought to make off limits by enacting the ADA. Moreover, as discussed in greater detail below, the medical effects approach to interpreting the ADA harmonizes with both existing standards of medical ethics generally, which require a physician to base treatment recommendations on an individualized assessment of the patient, and the ethically preferable approach to treatment decisions for disabled newborns, which entails an individualized prognostic strategy to determine what treatment option will advance the infant's best interests. Thus, neither the medical profession nor other health care providers should object to applying the ADA to medical treatment decisions consistently with the proposed approach, for such an application neither ignores nor intrudes on the admittedly complex process of ethically sound medical decision-making.

One could suggest that proposing a distinction between prohibited discrimination based on the existence of disability and permitted consideration of the disability's medical effects is disingenuous. Certainly, this distinction cannot be drawn throughout the ADA. ${ }^{280}$ Still, the na-

occupied, a classification that apparently reflected the severity of the resident's disability. See id. at 214. Cf. Anderson v. Little League Baseball, Inc., 794 F. Supp. 342 (D. Ariz. 1992) (holding that individualized assessment by public accommodation is necessary in determining whether the participation of a disabled individual poses a direct threat to the health and safety of others).

279. Of course, in those instances when the simple fact of a certain disability is proven to have a high statistical correlation with certain medical effects, use of the disability as a proxy for individual determination of those effects may be acceptable. The example that springs to mind is anencephaly, a congenital defect in which infants are born missing the cerebral hemisphere of the brain and with an open skull. Virtually all anencephalic infants die within one week of birth. See P.A. Baird \& A.D. Sodovnick, Survival in Infants with Anencephaly, 23 Clinical Pediatrics 268, 270 (1984). Because of this high level of statistical correlation, it should be permissible for a physician, having diagnosed anencephaly in an infant, to make subsequent decisions on the assumption that the infant's life span is limited to a week without pursuing an individualized assessment of the infant's own predicted life span. Of course, permitting the use of disability as a proxy for individual assessment in some cases raises the question of how properly to limit that class of cases. It seems that those limits should parallel the limits of proxy decision-making acceptable as a matter of medical ethics, but that the boundaries should be drawn somewhat more tightly to protect against the influence of stereotypes and prejudices within the medical profession.

280. Congress did not intend to prohibit an employer's consideration of a disability's existence in making a hiring decision, but then to allow the employer to refuse to hire the disabled applicant based on the effects of her disability. Title I of the ADA governs private employment and generally prohibits discrimination by an employer against a qualified "individual with a disability who, with or without reasonable accommodation, can perform the essential functions of the employment 
ture of medical decision-making seems to be sufficiently distinct from most of the types of decisions that the ADA covers to justify a distinctive approach. ${ }^{281}$ Ultimately, the issue is what it means to "discriminate" in the context of making medical decisions. Ethical medical decision-making should take into account all medical factors-disability-related or not-affecting a patient's condition and prognosis. ${ }^{282}$ Thus, to read the ADA as prohibiting a medical decision-maker from considering medical factors flowing from a disability would put the disabled patient, whether a competent adult or a newborn, in a different, arguably worse, position than the nondisabled patient, for the decisionmaker would be prohibited from fully assessing the patient's condition and prognosis to determine what treatment option is in the patient's best interests.

Another way of looking at the issue is that under the medical effects approach, a decision-maker's consideration of the medical effects of a patient's HIV infection or other disability in order to allow treatment in the best interests of the patient does not even constitute "discrimination" in the broad sense of the word because the patient is being treated the same as nondisabled patients: they should all have decisions made based on a thorough assessment of their individual conditions and prognoses. By contrast, neither the ADA nor the medical effects approach allows the use of disability as a proxy, for medical decision-making should not reflect prejudices or subjective assessments of a patient's social worth or be based on subjective predictions, in social rather than medical terms, of the patient's future quality of life. ${ }^{283}$

position that such individual holds or desires." 42 U.S.C. $\$ 12111(8)$. Discrimination is defined to include a failure to provide "reasonable accommodations to the known physical or mental limitations of an otherwise qualified individual with a disability." 42 U.S.C. \& 12112(b)(5)(A). Thus, under Title I, the effects of an employee's or applicant's disability triggers the employer's duty of reasonable accommodation, rather than allowing the employer to discriminate.

281. The proposed approach arguably could also apply in contexts other than medical treatment decisions. For example, decisions regarding rehabilitative services, like those at issue in Garrity, 522 F. Supp. at 171, would seem well suited for this approach. A consideration of all the different contexts where decisions should be assessed under the proposed approach is beyond the scope of this Article, but a common thread would seem to be decisions that are properly made in the best interests of the recipient of the goods or services rather than in the economic interest of the decision-maker.

282. One can imagine other factors, such as age or homelessness, that could be viewed as illegitimate grounds for discrimination, but that could produce medical effects that ethically should be taken into account in making individual treatment decisions. For example, a patient's extreme youth, while not in and of itself a ground for denying treatment, may be relevant to the patient's ability to metabolize a certain drug or the ease with which broken bones will mend. Similarly, an ill child's homelessness should not itself be a ground for denying treatment, but may be relevant to assessing what treatment regimen is in the individual child's best interests, because one effect of homelessness may be that an extended treatment regimen is less likely to be completed.

283. Another objection to the medical effects approach is that it may involve courts 


\section{Normative Justification of the Medical Effects Approach}

Assuming that the proposed medical effects approach permits application of the ADA to medical treatment decisions in a fashion that responds to and answers the medical complexity argument, at least two questions remain: Why should we, as a normative matter, apply the ADA to treatment decisions in the absence of evidence of specific congressional intent? Moreover, won't applying the ADA to individual medical treatment decisions undesirably tie the hands of policymakers who may seek to constrain the escalation of health care costs by rationing medical services based on their cost effectiveness?

1. Medical Ethics and Congressional Intent.-The absence of evidence of specific congressional intent with respect to the applicahility of the $\mathrm{ADA}$ to medical treatment decision-making raises two questions. First, is that absence of specific intent in itself fatal to an argument that the ADA should be interpreted to apply to medical decision-making? Second, if the answer to the first question is negative, does evidence of Congress' general intent in enacting the ADA provide any guidance as to the statute's applicability to medical decision-making?

The medical profession focused on the former question in opposing HHS's section 504 regulations by arguing that applying antidiscrimination law to selective nontreatment would intrude on and

in prolonged and complicated litigation attempting to determine whether a treatment decision was based on the existence of disability or on the relevant medical effects of disability, a task which some might characterize as second guessing medical judgments. See United States v. University Hosp., 729 F.2d 144, 157 (2d Cir. 1984) (determining whether a medical judgment is discriminatory "would invariably require lengthy litigation primarily involving conflicting expert testimony to determine whether a decision to treat, or not to treat, . . . was based on a 'bona fide medical judgment,' however that phrase might be defined").

Yet, though the inquiry is frequently difficult in discrimination cases of all types, the role of the finder of fact is to make judgments as to how and why people acted. For example, in a case alleging discrimination in medical decision-making, the plaintiff may be able to produce expert medical testimony as to why the plaintiff's HIV infection (or other disability) created no medical effects justifying the withholding of treatment. Likewise, the plaintiff may try to prove the decision-maker's past record of recommending or providing treatment to nondisabled patients who were otherwise similarly situated to plaintiff. "Just because the inquiry is difficult, the court is not justified in ignoring the plain mandate of the statute and refusing the enforce it." Glanz v. Vernick, 750 F. Supp. 39, 46 (D. Mass. 1990). The same judge in Glanz II suggested that the evidentiary approach to $\$ 504$ cases set forth in Pushkin v. Regents of the Univ. of Colo., 658 F.2d 1372, 1385, 1387 (10th Cir. 1981), would be appropriate for determining whether a plaintiff was "otherwise qualified" for the treatment at issue:

The plaintiff must first make out a prima facie case that he was otberwise qualified for surgery, and only then does the burden shift to the defendant to show that the plaintiff's handicap made him unqualified. The plaintiff, however, must still be given an opportunity "to prove either that the reason given by defendants is a pretext or that the reason . . . 'encompasses unjustified consideration of the handicap itself.' "'

Glanz II, 756 F. Supp. 632, 638 (D. Mass. 1991) (citations omitted). 
regulate the medical decision-making process, a result neither specifically contemplated nor intended by Congress in enacting section 504 . A similar argument is likely to be voiced in opposition to any contention that the ADA should be read to apply to medical decision-making. This argument carried some force in the context of the Reagan administration's section 504 regulations, which sought to compel the treatment of handicapped infants regardless of any medical effects their handicaps might have. This argument loses its force, however, when raised in opposition to applying the ADA consistently with the medical effects approach proposed in this Article.

As discussed in Part IV above, medical ethics generally require that treatment recommendations for a competent patient reflect the individual patient's best interests, and the morally preferable standard for assessing treatment decisions made for disabled or otherwise imperiled newborns requires that decisions be made in the infant's own best interests, based on an ongoing individualized assessment of the infant's condition and proguosis. ${ }^{284}$ These ethical standards are fully consistent with the proposed legal standard for applying the ADA. Under either standard, for example, persons deciding whether an HIV-infected infant should undergo surgery to correct a ventriculoseptal defect can and should consider what effects the infection has on the individual infant in terms of its condition and proguosis and the advisability of surgery. Under neither standard, however, can the decisionmaker base its decision simply on the fact of infection; in other words, using the fact of infection as a proxy for individualized assessment is neither ethically nor legally acceptable.

Rather than intruding on medical decision-making by introducing new standards and considerations, adopting a medical effects approach to applying the ADA to medical decision-making thus reaffirms existing ethical medical practice. ${ }^{285}$ Since the ADA can be applied to medical decision-making in a manner requiring no change in how or on what basis decisions should be made, the legislative history's silence with respect to the statute's applicability in this context does not in itself seem dispositive. If anything, one could argue that Congress' failure to exempt medical treatment decisions from the ADA's coverage, as it did

284. See supra text accompanying notes 177-189. Although this standard is not universally accepted, it, or a similar standard, has been adopted by a number of the leading scholars and groups in the field of bioethics. See, e.g., Weir, supra note 2, at 194-95; Arras, supra note 92, at 105-06; Newborns Project, supra note 2, at 15-16; President's Commission, supra note 177, at 214-17; Rhoden, supra note 185, at 39-40. But cf. Rhoden, supra note 2, at 1318-22 (proposing quality of life standard that focuses on infant's potential for relational capacity).

285. Applying the ADA to medical decision-making will certainly constrain the practice to the extent that decision-makers will no longer be able to act inconsistently with ethical standards without risking legal scrutiny of decisions that use disability as a proxy. The day appears to be past, however, when the medical profession acted as sole arbiter of the propriety of its members' actions. 
insurance underwriting decisions, ${ }^{286}$ shows Congress' intent that the statute's coverage otherwise be comprehensive. ${ }^{287}$

So, if the absence of specific congressional intent is not alone fatal to the proposition that the ADA should be read to apply to medical treatment decisions, what does Congress's general intent in enacting the statute indicate? Indeed, applying the ADA to medical treatment decisions pursuant to the medical effects approach comports with Congress' desire that the ADA function to protect vulnerable persons from the ill effects of discrimination. Although much of the ADA's legislative history focuses on giving persons with disabilities equal opportunities for economic empowerment, the history also displays concern for the historical social effects of disability discrimination. ${ }^{288}$ For example, the legislative history includes testimony from the Commission on the HIV Epidemic highlighting the serious repercussions of the widespread discrimination against persons with HIV infection. ${ }^{289}$

In light of Congress' concern with protecting persons with disabilities not only from the adverse economic effects of discrimination, but also from its social and personal costs, protecting disabled patients, including HIV-infected infants, against medical treatment decisions

286. See 42 U.S.C. $\S 12201$ (c) (1992).

287. Moreover, the impact on existing medical practice will be limited because the ADA's protection will not be triggered when a competent patient or a parent or other family member is making the treatment decision, but only when an actor covered by the $\mathrm{ADA}$, such as a state agency, a hospital, or physician, decides what treatment will be recommended or provided. Nonparental decision-making for a disabled infant provides one example of such a scenario; others might include treatment recommendations for a competent patient or actual treatment decisions made for a mentally incompetent ward of the state or for a victim of spinal cord injury who also temporarily suffers cognitive impairment. Cf. David R. Patterson et al., When Life Support is Questioned Early in the Care of Patients with Cervical-Level Quadriplegia, 328 New Eng. J. Med. 506, 508 (1993) (warning against too hasty decision-making by family members or medical staff for a temporarily incompetent patient).

288. See, e.g., S. Rep. No. 101-116, 101 st Cong., 1st Sess. 32 (1989), reprinted in Legislative History, supra note 227 , at 53 ("People with disabilities as a group occupy an inferior status socially, economically, vocationally, and educationally."); id. at 54 ("discriminatory treatment of handicapped persons can occur in almost every aspect of their lives”); H.R. Rep. No. 101-485, 10 st Cong., 2d Sess., pt. 2, at 274 (1990), reprinted in Legislative History, supra note 227, at 304, 324 ("Discrimination produces fear and reluctance to participate on the part of people with disabilities.").

As Arlene Mayerson of the Disability Rights Education and Defense Fund testified:

The discriminatory nature of policies and practices that exclude and segregate disabled people has been obscured by the unchallenged equation of disability with incapacity and by gloss of "good intentions." The innate biological and physical "inferiority" of disabled people is considered selfevident. This "self-evident" proposition has served to justify the exclusion and segregation of disabled from all aspects of life. The social consequences that have attached to being disabled often bear no relationship to the physical or mental limitations imposed by the disability.

1d. at 322.

289. See id. at 313 . 
based on prejudices and inaccurate assumptions seems well within the realm of the kind of discrimination that the ADA seeks to eradicate. Moreover, although the ADA does not treat environmental or social disadvantages as disabilities, because poverty, racial, or ethnic minority status and lack of strong family support combine to make most HIVinfected infants particularly vulnerable, we, as a society, should be particularly vigilant in protecting those infants from discrimination on the prohibited ground of disability. ${ }^{290}$ Applying the ADA to treatment decisions for infants infected with HIV reflects the ethos that Congress sought to advance in enacting the statute.

2. Making Individual Treatment Decisions vs. Making Policy.-A final objection to applying the ADA to medical treatment decisions is that doing so would prevent policymakers from making informed, rational decisions about what kinds of medical care our society is willing to pay for. Some may argue that hard times call for hard choices and that the ADA should not be interpreted to tie the hands of policymakers making those hard choices by preventing them from considering disability, among other factors, in deciding what we should pay for. In light of media reports regarding the relative cost-ineffectiveness of much neonatal intensive care ${ }^{291}$ and the growing costs of caring for, without curing, persons infected with HIV,292 this objection seems a particularly likely response to this Article's focus on decision-making for infants with HIV.

This objection, however, because it fails to distinguish between individual medical treatment decisions and policy decisions regarding the funding or availability of medical services, is inapposite to this Article's thesis. The former decision is made at the micro level and, as an ethical matter, should focus on the individual patient's condition and proguosis and seek to advance his best interests. The latter decision, by contrast, is made at the macro or policy level by balancing competing interests in society. In light of the different interests to be advanced, the two types of decision necessarily differ in nature and process and, as a practical matter, are normally made by different decision-makers. ${ }^{293}$ This Article focuses on how the ADA should be interpreted to apply to the former decision-an individual medical treatment decision.

The ADA presumably applies to policy decisions regarding funding for medical treatment-not according to the proposed medical ef-

290. See Rev. Raymond O'Brien, Discrimination: The Difference with AIDS, 6 J. Contemp. Health L. \& Pol'y 93, 96 (1990) (advocating unique and special consideration of HIV-infected persons because AIDS afflicts those already burdened by past histories of intensive discrimination: homosexuals, drug-users, and minorities).

291. See, e.g., Elisabeth Rosenthal, As More Tiny Infants Live, Choices and Burdens Grow, N.Y. Times, Sept. 29, 1991, at A1, A26.

292. See supra note 76.

293. For example, a state's legislature, in consultation with health officials, will establish coverage provisions for the state's Medicaid program. An individual treating physician, by contrast, decides what treatment to recommend for an individual patient. 
fects approach, but according to the standard set forth by the Supreme Court in Alexander $v$. Choate. ${ }^{294}$ In that case the Court considered a section 504 challenge to Tennessee's policy of limiting Medicaid reimbursement for hospital stays to fourteen days per year. The Court rejected the plaintiffs' arguments that the policy's adverse impact on disabled persons, who tend to have greater hospitalization needs, constituted a violation of section 504 . Instead, while assuming that section 504 reaches at least some conduct having a disproportionate impact on the handicapped, ${ }^{295}$ the Court found the fourteen-day limitation acceptable because it was neutral on its face and did not "invoke criteria that have a particular exclusionary effect on the handicapped" or "distinguish between those whose coverage will be reduced and those whose coverage will not on the basis of any test, judgment, or trait that the handicapped as a class are less capable of meeting or less likely of having."296

Thus, the standard erected in Alexander appears to permit policy level decisions rationing medical care as long as the rationing criteria do not have a particular exclusionary effect on persons with disabilities. In August 1992 the Secretary of HHS applied this standard to Oregon's request for Medicaid waivers allowing the State to proceed with a rationing scheme. Oregon sought to reform its Medicaid program to cover all residents below the federal poverty line by implementing a rationing scheme based on a 709-item list of "condition-treatment pairs" prioritized in the order in which they would be funded by the State. Oregon policymakers ranked the condition-treatment pairs based on the results of a complex process using a Quality of Well-Being scale to rank the effectiveness of various treatments in terms of tbeir medical outcomes and the extent to which the treatments advanced "basic values," such as functioning, quality of life, length of life, and social activity. ${ }^{297}$

The Secretary rejected Oregon's waiver request on the grounds of its apparent conflict with the ADA. ${ }^{298}$ Because the prioritization pro-

294. 469 U.S. 287 (1985).

295. The Court, however, rejected "the boundless notion that all disparate-impact showings constitute prima facie cases under § 504." Id. at 299.

296. Id. at 302.

297. For a description of this process, see Robert M. Kaplan, A Quality-of-Life Approach to Health Resource Allocation, in Rationing America's Medical Care: The Oregon Plan and Beyond 60. (Martin A. Strosberg et al. eds., 1992) (hereinafter Rationing America's Medical Care].

298. Prior to the Secretary's rejection, various critics of Oregon's plan had focused on the plan's implementation of a rationing scheme that affected only the poor, did little to control provider fees or physician incomes, and was predicted to have a disproportionate adverse effect on women and children. For a variety of perspectives on Oregon's plan, see Rationing America's Medical Care, supra note 297. Prior to Secretary Louis Sullivan's rejection of the plan, however, health policy analysts had paid little or no attention to the potential effect of the Oregon plan on persons with disabilities. 
cess for the condition-treatment pairs had included telephone surveys of the general public that may have "quantifie[d] stereotypic assumptions about persons with disabilities" and adjustments made by policymakers on the basis of community values, including "quality of life" and "ability to function," the Secretary found "considerable evidence that [the list] was based in substantial part on the premise that the value of the life of a person with a disability is less than the value of the life of a person without a disability. This is a premise that is inconsistent with the ADA."299

Suggesting that Oregon revise its plan to bring it into conformity with the ADA, the Secretary cited Alexander $v$. Choate as authority for the proposition that Oregon could consider a wide range of factors, including "the cost of medical procedures, the length of hospital stays, prevention of death, and prevention of contagious diseases," in allocating resources consistently with the ADA.300 This approach, if adopted by courts interpreting the ADA, would permit health policymakers to establish rationing schemes that do not rely on suspect criteria. For example, the $\mathrm{ADA}$ would seem to allow a state to limit its funding of medical treatment for individuals having a one-year life expectancy of less than fifty percent to provision of comfort care or to a set dollar amount. This limitation, while having a significant impact on some persons with disabilities, such as persons suffering full-blown AIDS, would also limit funding of care for some elderly persons with multiple organ systems failures, for persons seeking some organ transplants, for some extremely premature newborns, and for some victims of severe trauma. Thus, it would avoid any particular exclusionary effect on persons with disabilities. ${ }^{301}$

299. Letter from Louis W. Sullivan, Secretary of Health and Human Services, to Barbara Roberts, Governor of Oregon, Aug. 3, 1992 (with accompanying three-page "Analysis Under the Americans with Disabilities Act (ADA) of the Oregon Reform Demonstration").

300. Id. For further discussion of the Secretary's rejection of the Oregon plan, see Alexander Capron, Oregon's Disability: Principles or Politics?, Hastings Center Rep., Nov.-Dec. 1992, at 18; Paul T. Menzel, Oregon's Denial: Disabilities and Quality of Life, Hastings Center Rep., Nov.-Dec. 1992, at 21.

In November 1992, after attempting to respond to the Department's concerns by eliminating all references to quality of life and cutting certain information obtained from the telephone surveys, Oregon resubmitted its plan. See Diane S. Lund, Medicaid Reform Plan Revised, Resubmitted, Am. Med. News, Dec. 7, 1992, at 14. The Secretary of HHS approved the proposal on March 19, 1993, conditioned upon Oregon's meeting a number of restrictions designed to prevent the scheme's discrimination against persons with disabilities. For example, in deciding what funding priority a treatment for a given condition will receive, Oregon cannot consider whether the treatment will eliminate all of a patient's "functional limitations," so that treatment that is effective in responding to a condition will not be given a lower priority simply because it does not respond to pre-existing disabilities. See Robert Pear, U.S. Backs Oregon's Health Plan for Covering All Poor People, N.Y. Times, Mar. 20, 1993, at A8.

301. The ADA's express requirement (not present in \$ 504) of a public entity's "reasonable modifications to rules, policies, or practices," 42 U.S.C. $\$ 12131$ (2) (Supp. 
Although difficulties in applying this standard can be easily imagined, Alexander $v$. Choate's standard clearly focuses on medical resource allocation decisions made at a policy level to balance and resolve competing societal interests. The locus of individual medical treatment decisions, by contrast, should remain centered around the individual patient's medical condition and best interests. Granted, the ability to implement a treatment decision or recommendation for an individual patient may be affected by the independent decision by policymakers regarding what medical services a state program will fund, ${ }^{302}$ but this interaction does not mean the two decisions must or should be governed by the same standard. Applying the ADA to individual treatment decisions pursuant to the medical effects approach proposed above will not subject policymakers to any greater constraints than they already face in making rationing decisions.

\section{Recommendation}

In light of the foregoing analysis, the medical effects approach to applying the ADA to medical treatment decisions seems to offer the best alternative for addressing the incipient problem of selective nontreatment of infants infected with HIV. The proposed approach both responds to the medical complexity argument without simply deferring to it and harmonizes with current ethical standards of medical decisionmaking. The latter point is significant for two reasons: First, as discussed above, it largely defuses the argument that Congress's failure to extend the ADA specifically to medical treatment decisions should preclude that application. Second, any opposition by the medical profession to an application of the ADA that merely requires physicians to act consistently with the profession's own ethical standards will be difficult to justify.

III 1991) (defining "qualified individual with a disability"), seems unlikely to lead courts interpreting the ADA to adopt a standard different from Alexander $v$. Choale's. In that case the Court recognized, based on regulations issued under $\$ 504$, that a public benefit "cannot be defined in a way that effectively denies otherwise qualified handicapped individuals the meaningful access to which they are entitled; to assure meaningful access, reasonable accommodations in the grantee's program or benefit may have to be made." Alexander v. Choate, 469 U.S. 287, 301 (1984) (footnote omitted). The Court, however, rejected as "simply unsound" the disabled plaintiffs' contention that because of their greater need for extended inpatient care, the state had to provide the disabled with more than fourteen days of coverage in order to provide meaningful access. See id. at 302-03.

302. For example, a physician may recommend a liver transplant for a patient based on the physician's individualized assessment of the patient's condition and best interest but may be unable to perform the transplant because the state made a policy decision not to fund such procedures. Although the outcome in this case is the same as if the physician had engaged in the rationing herself, the division of responsibility suggested in the text assures that the physician is not subjected to a conflict of interests in seeking to advance both the patient's best interests and society's interest in conserving resources. See Hirshfeld, supra note 160, at 1840-42. 
Concluding that the ADA should be interpreted as applying to medical treatment decisions pursuant to the proposed medical effects approach, however, does not answer the question: How do we get from here to there, particularly with respect to nontreatment of infants with HIV infection? Although a conclusive, detailed recommendation regarding how best to implement the proposed approach is beyond the scope of this Article, some general observations and a preliminary recommendation are in order. One response to the question of how to get from here to there would be to leave to the courts the role of interpreting the ADA in the medical treatment context and to leave to parties claiming nontreatment and their advocates the responsibility of propounding a medical effects approach. Claims of discriminatory medical decision-making could be brought by plaintiffs in private civil actions, by HHS in compliance actions under the public entity provisions of the $A D A,{ }^{303}$ or by the Attorney General in an enforcement action under the statute's public accommodations provisions. ${ }^{304}$ This alternative requires waiting until harm sufficient to justify legal action occurs to a party who either has access to the courts or the knowledge to refer the complaint for agency or Attorney General investigation and enforcement. Nonetheless, these enforcement options may be adequate to provide competent adult patients with disabilities a forum in which to advance the medical effects approach. As a practical matter, however, even if HIV-infected infants are gravely injured by discriminatory nontreatment, the likelihood that lawsuits will be brought or complaints filed on behalf of members of this "ultimate minority" seems relatively small. ${ }^{305}$ Furthermore, even if the medical effects approach is argued in court, the relatively conservative nature of the current federal judiciary suggests that courts may not be willing to rule creatively in the absence of evidence of specific congressional intent. ${ }^{306}$ Our wait for judicial adoption of the medical effects approach could be long.

An alternative approach would be for the Department of Justice

303. Regulations issued by the Department of Justice (DOJ) essentially allow complaints claiming discrimination by a public entity to be filed with either DOJ itself or the federal agency designated to investigate alleged violations by the specific type of public entity involved. Complaints filed with DOJ will be referred to the appropriate designated agency. See 28 C.F.R. $\$ \$ 35.170,35.171$ (1992). The regulations designate HHS as having responsibility for implementing compliance procedures for all public entities engaged in "activities relating to health care and social services, including ... the operation of health care and social service providers and institutions." 28 C.F.R. $\S 35.190(\mathrm{~b})(3)$.

304. Regulations issued by DOJ under the public accommodations provisions of the ADA, 42 U.S.C. $\$ 12188$, in addition to allowing for private suits, also provide for investigations by the Attorney General of allegations of statutory violations and for civil actions by the Attorney General. See 28 C.F.R. $\S \S 36.501-36.503$.

305. Cf. Gittler \& Rennert, supra note 78, at 1386-87 (describing variety of obstacles to obtaining relief under antidiscrimination laws for women and children with HIV infection).

306. See Parmet, supra note 252, at 339. 
(DOJ) to promulgate regulations applying the ADA to medical treatment decisions pursuant to a medical effects approach and establishing a compliance or enforcement mechanism specific to this context. Issuing regulations that impose binding obligations on medical providers or state agencies, however, would tempt the fate that befell HHS's section 504 regulations in Bowen. ${ }^{307}$ Empirical evidence of the extent of discriminatory nontreatment of HIV-infected infants, or of other disabled patients, simply has not been gathered. DOJ currently is unlikely to be able to develop an administrative record containing sufficient evidence of an existing problem to warrant legislative rulemaking.

Another option, however, is available to the Department of Justice: despite the lack of hard evidence regarding the measure of discriminatory treatment or nontreatment decisions, the agency can issue an interpretive rule without going through the notice and comment process required by the Administrative Procedure Act for legislative rulemaking. ${ }^{308}$ An interpretive rule, while not binding on private parties, the agency itself, or the courts, ${ }^{309}$ allows the agency to express its interpretation of what existing law requires. ${ }^{310}$ Thus, by issuing an interpretive rule, DOJ could give the public, including hospitals, physicians, and state child welfare agencies, clear notice as to what the ADA means in the context of individual treatment decisions for all patients with disabilities without undergoing the time, expense, and evidentiary requirements of notice and comment rulemaking.

Of course, one could view the issuance of an interpretive rule without binding force as a weak-kneed response, little better than no response at all. I would argue, however, that the issuance of an interpretive rule, at least as an initial response, not only is fitting in light of the current uncertainty regarding the extent of discriminatory medical decisions, but may serve to advance the ADA's goals better than either legislative rules or judicial interpretations. The ADA calls for the pulling down of barriers for persons with disabilities and the dispelling of mistaken and prejudiced attitudes held by so many in our society. In some instances, these goals may be better advanced by promoting self-examination and education than by either further legislation or litigation. ${ }^{811}$ This focus on self-awareness and behavioral

307. See supra notes $114-118$ and accompanying text.

308. See 5 U.S.C. $\$ 553$ (1988).

309. See Batterton v. Marshall, 648 F.2d 694, 702 (D.C. Cir. 1980). By enforcing its interpretation of existing law, the agency does give the interpretation some binding effect. On judicial review, however, the agency's interpretation, while given some weight, is not determinative. Instead, the agency must defend the interpretation as if it had not issued the rule at all. See Morton v. Ruiz, 415 U.S. 199 (1974).

310. American Hosp. Ass'n v. Bowen, 834 F.2d 1037, 1045 (D.C. Cir. 1987).

311. As two commentators have remarked on this point:

The availability and accessibility of legal relief for women and children with HIV infection is only one indicia of the effectiveness of antidiscrimination laws. Equally, if not more important, is whether and to what extent 
change is reflected in some of the regulations implementing the ADA. For example, public entities are required to engage in a self-evaluation of their existing policies and practices to identify and correct any that are inconsistent with the $\mathrm{ADA}, 312$ and the preferred remedy when an investigating agency finds noncompliance by a public entity is the negotiation of a voluntary compliance agreement. ${ }^{313}$ DOJ's issuance and dissemination of a rule interpreting the $\mathrm{ADA}$ to apply to individual medical treatment decisions and describing the rationale behind the medical effects approach could operate as an influential step in this education process. ${ }^{314}$

The evolution over the past twenty years in public attitudes towards persons with mental retardation and with disabilities generally, and the resulting decrease in the number of physicians recommending nontreatment of infants with Down syndrome, ${ }^{315}$ illustrate the potential for success in a consciousness-raising approach. In addition, rather than immediately approaching medical decision-makers in an adversarial posture, initially issuing an interpretive rule seeks to encourage them to perform their own ethical duties. At the same time, though, DOJ and HHS can implement the interpretive rule in pursuing the compliance and enforcement procedures already established under the ADA. ${ }^{316}$

antidiscrimination laws will actually serve to prevent the occurrence of discrimination against these women and children. Underlying the enactment of these laws is the assumption and the expectation, that such laws will produce social change through the promotion of behavioral and attitudinal changes towards those with HIV infection, and that there will be substantial compliance with such laws.

Gittler \& Rennert, supra note 78, at 1387. Cf. Dick Thornburgh, The Americans with Disabilities Act: What it Means to All Americans, 64 Temp. L.Q. 375, 384 (1991) ("The ADA is social legislation to end barriers, not an instrumentality for continuous and acrimonious litigation. Still, we do need some consciousness-raising about Americans with disabilities, especially since our mistaken attitudes are often so well-meaning and so ingrained.").

312. See 28 C.F.R. $\$ 35.105$ (1992).

313. See 28 C.F.R. $\$ 35.173$ (1992).

314. Of course, education regarding legal requirements is not the only education whose need is suggested by responses to the JAMA survey. In a letter commenting on the survey's results, the Chairman of the American Academy of Pediatricians Task Force on Pediatric AIDS remarked: "The need for renewed and continuing efforts to educate health care workers is evident from this article." He also noted, consistently with this Article's thesis, that "medical ethics dictate that therapeutic decisions for the infant should not be determined solely on the basis of the HIV serologic status of the mother or infant." Stanley A. Plotkin, Infants at Risk for the Acquired Immunodeficiency Syndrome, 267 JAMA 1469, 1469 (1992). The influence of education and experience was apparent in the results of the survey itself, which showed that respondents who reported more experience with infants thought to be infected with HIV were somewhat more likely to recommend more treatment for infants at risk for or known to be infected with HIV. See Levin et al., supra note 5, at 2979.

315. See supra notes $18-2 \mathrm{I}$ and accompanying text.

316. See supra notes $303-304$. 
Of course, if issuing an interpretive rule adopting the medical effects approach proves ineffective and discriminatory nontreatment of HIV-infected infants or discriminatory medical decisions for other patients with disabilities swells into a common problem, a more aggressive response may then be called for. One possibility would be the adoption of some type of ombudsman program within DOJ's or HHS's Office of Civil Rights for the monitoring of medical treatment decisions for disabled infants and children made by, for example, state child welfare agencies. Or, if evidence is gathered demonstrating that discriminatory nontreatment has become a significant problem, the Department of Justice could then issue regulations specifically targeted to the problem identified and providing for more stringent regulatory oversight. Today, however, the early days of the ADA present DOJ with a public primed for education as to the Act's meaning and philosophy. Consequently, the issuance of an interpretive rule applying the ADA to medical treatment decisions currently presents the best first step for getting from here to there.

\section{Conclusion}

Evidence of physician attitudes favoring the withholding of needed medical treatment from infants infected with HIV compels a reassessment of the applicability and adequacy of existing law in dealing with selective nontreatment. Although we can hope to have learned some lessons from the Baby Doe controversy of the mid-1980s, whether the legislation emerging from that controversy, the Child Abuse Amendments of 1984, has ever adequately dealt with the problem of nontreatment remains far from clear. Today, the medical and social characteristics of most infants infected with HIV introduce new variables into our assessment of that legislation. At stake are the lives of infants who, for reasons of class, race, and HIV infection, are both particularly vulnerable to having their lives devalued and relatively likely to have decisions regarding their medical treatment made by someone other than their parents. These factors, when combined with the prognostic uncertainty characteristic of perinatally transmitted HIV infection, are likely to diminish further the Child Abuse Amendments' ability to assure an effective response to nontreatment of these infants.

The Americans with Disabilities Act, by contrast, offers greater promise as an adequate legal response to nontreatment based on HIV infection. Although the ADA's applicability to individual medical treatment decisions is unclear from the statute's face and legislative history, normative considerations amply justify interpreting the ADA as covering such decisions. Applying the ADA to treatment decisions pursuant to the medical effects approach proposed by this Article respects the legitimate complexity of the medical decision-making process, but prohibits the interjection of illegitimate considerations of disability into that process. Use of the medical effects approach would not create new 
burdens, unanticipated by Congress, for medical decision-makers; rather, the approach simply would harmonize legal protection with existing ethical standards. Although using the medical effects approach to judge the legitimacy of treatment decisions for infants infected with HIV doesn't promise easy answers in hard cases, it does offer a sensitive way of ensuring that the ADA's revolution reaches infants infected with HIV and all patients with disabilities. 